\title{
البحثَ الأول:
}

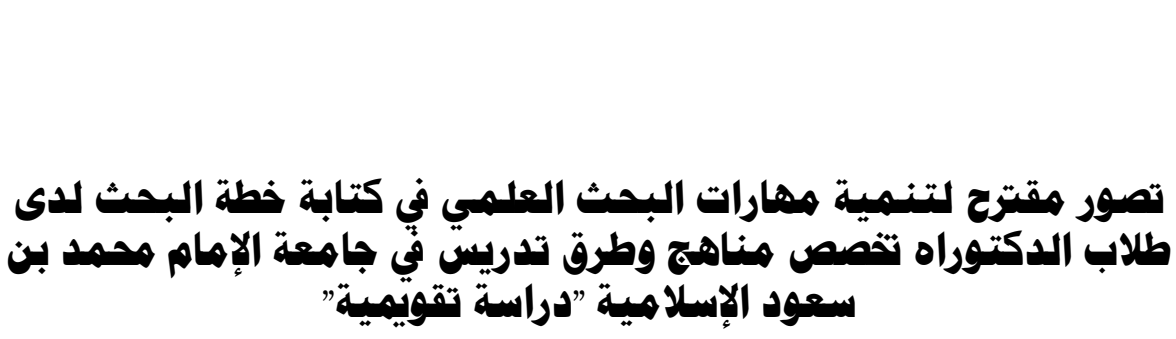

: إلحاל

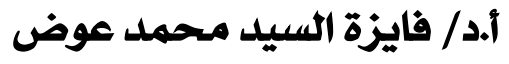

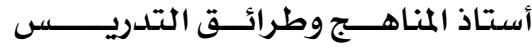

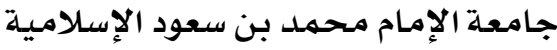

د/غاليتّ بنت حمد سليمان السليم

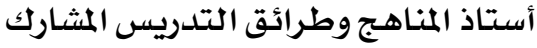
جامعة الإمام محمدل بن سعود الإسلاميلة المتارية 



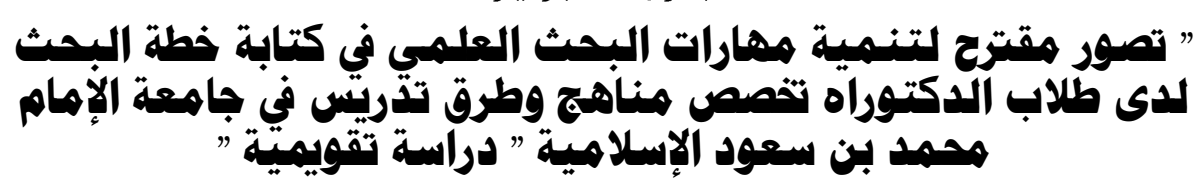

| أد/ فايزة السيـل محمـل عوض

د/غاليتً بنت حمل بن سليمان السليب

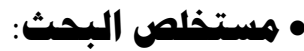

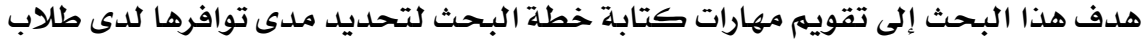

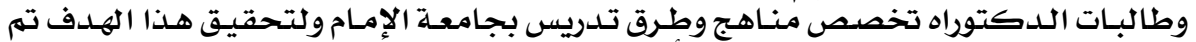

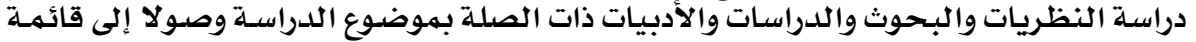

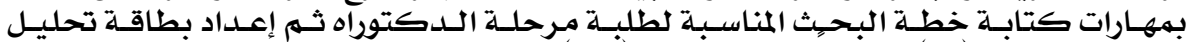

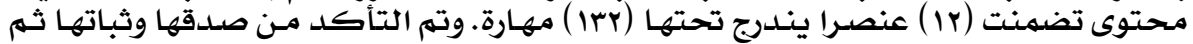

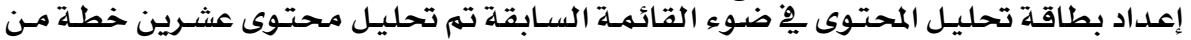

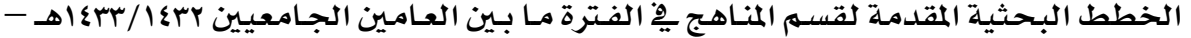

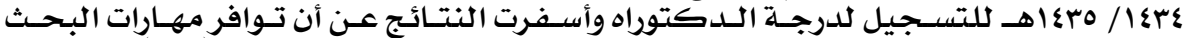

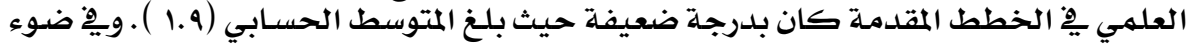

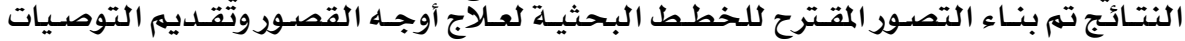

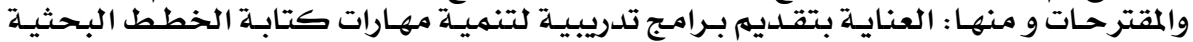

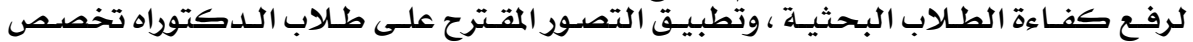

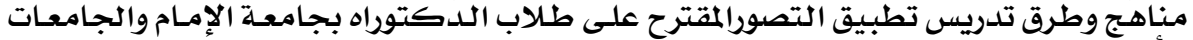

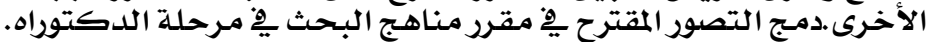

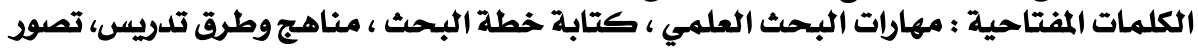
مقترح

A Suggested Paradigm for the Development of Scientific Research Skills in Writing the Research Plan for doctoral Students Curriculum and Instruction at Al-Imam Muhammad bin Saud Islamic University, "Evaluation Study" Galya H. Al Sulim Faiza ElSayed Mohamed Abstract:

This study aimed to evaluate writing research plan skills to determine the availability to the doctoral students in Curricula and Instruction specialist at Imam University. To achieve this goal a review of research studies and related literature has been done leading to a list of research plan writing skills that appropriate to doctoral students, included (12) components and 132 sub skills. Content analysis tool has been designed based on it.The validity and reliability of the previous skills and content analysis tool were confirmed. Twenty research plans that were submitted to curriculum and instruction department between 1432/1433 E-1434/1435 h years were analyzed.The study findings were: the availability of scientific research plans writing skills were weak as they hit the arithmetic average (1.9). In light of the results a proposed plans of research plan writing skills has been designed and presented.

Key words : scientific research skills, writing research plan skills, Curricula and Instruction, proposed plans 


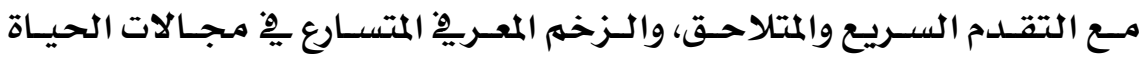

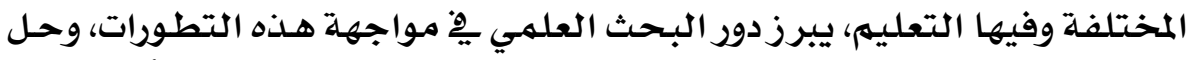

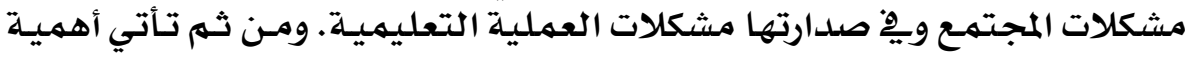

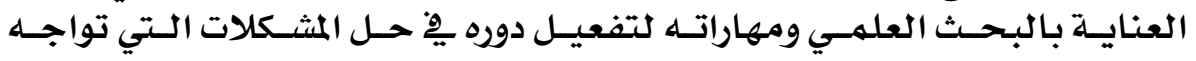

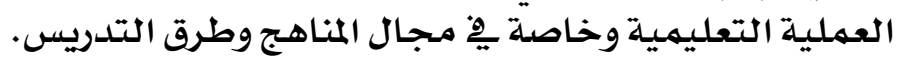

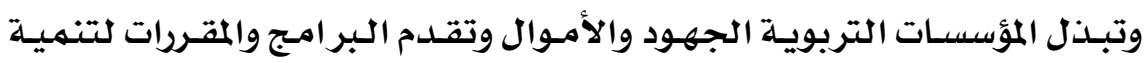

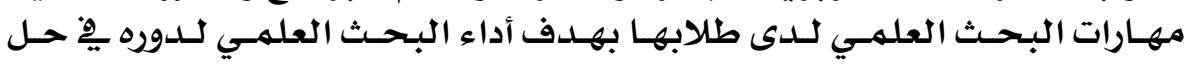

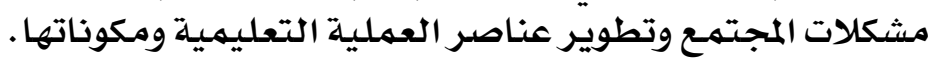

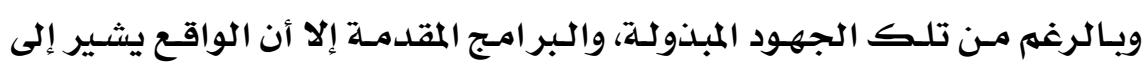

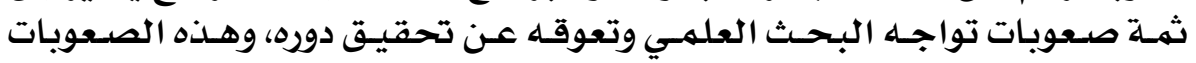

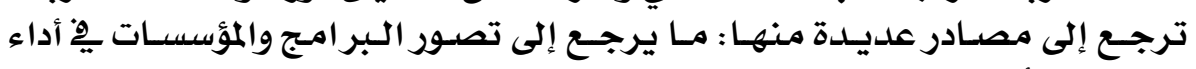

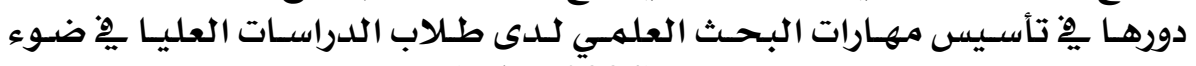

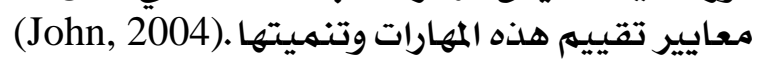

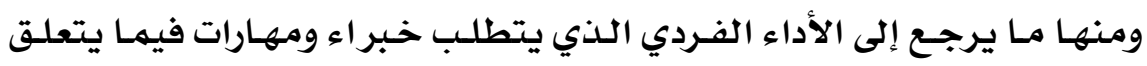

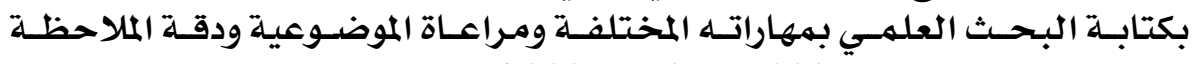

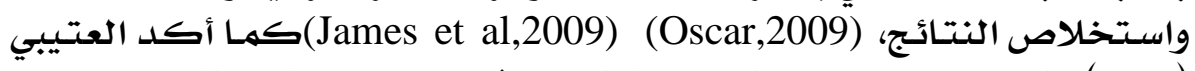

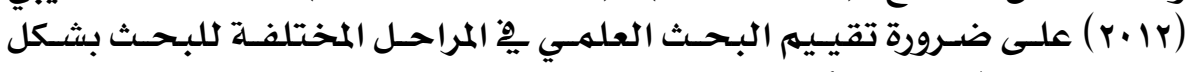

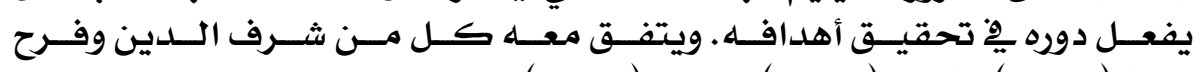

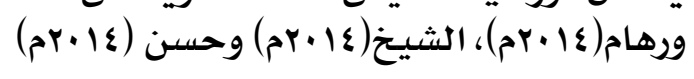

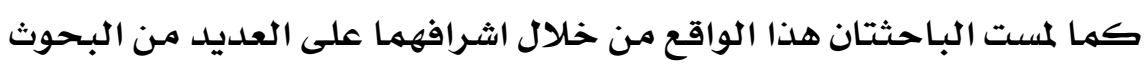

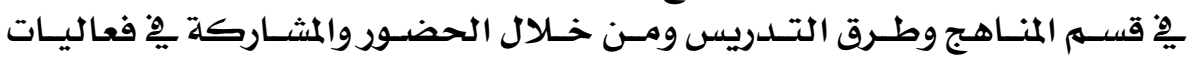

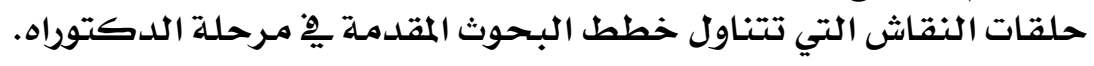

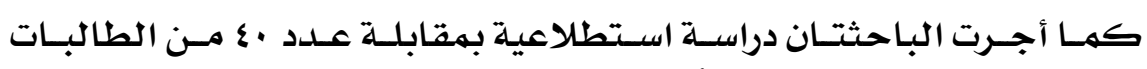

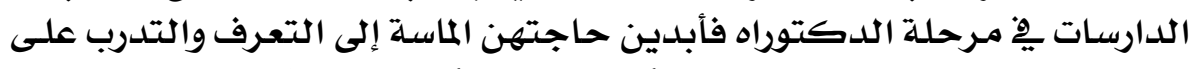

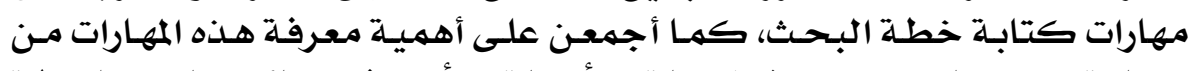

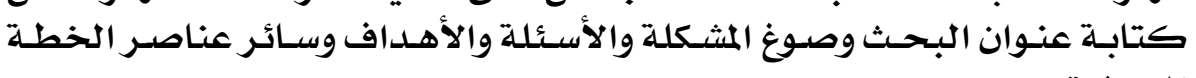

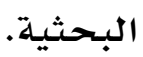

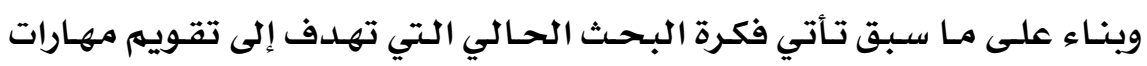

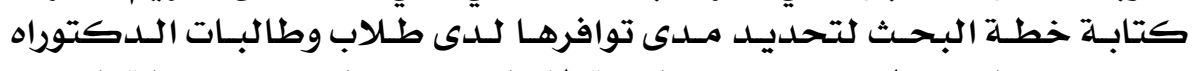

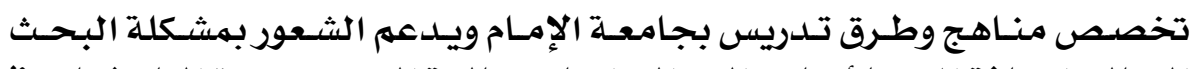

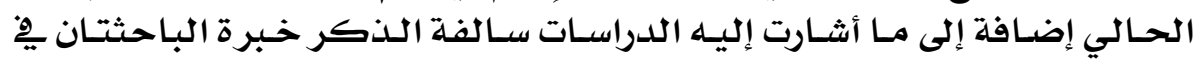

\section{$1 \wedge$}

\section{دراسات عربية في التربية وعلم النفس (ASEP)}




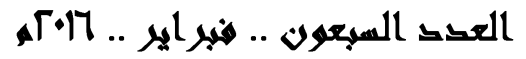

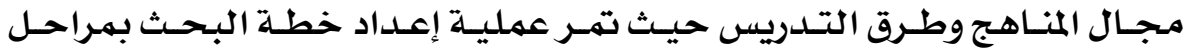

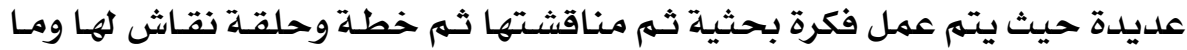

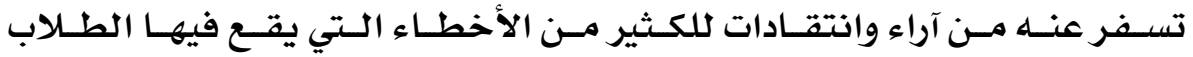

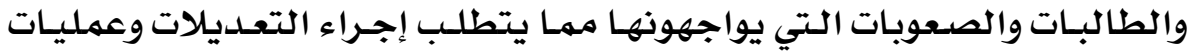

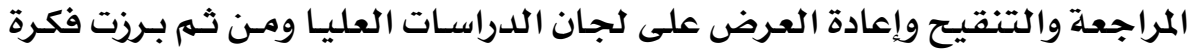

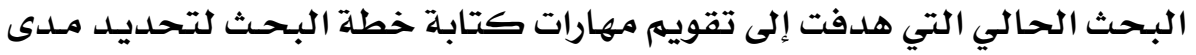
توافرها لدى طلاب وطالبـات الدهتوراه تخصـص منـاهـج وطـرق تدريس وتقـديهم

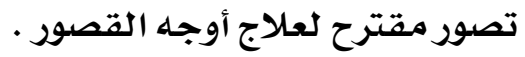

ولتحقيـق هـذا الهــف سـيتتم دراسـة النظريـات والبـحـوث والدراسـات والأدبيـات

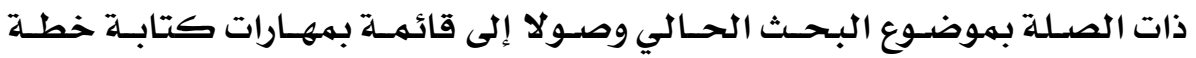

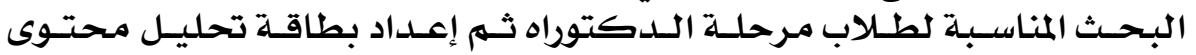

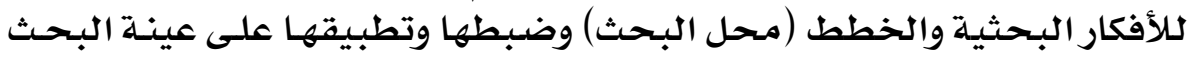

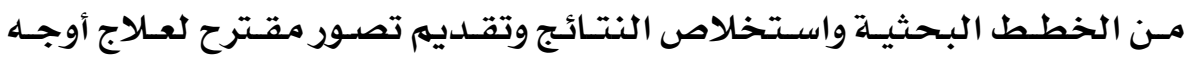
القصور وتقديه التوصيات والمقترحات.

• مششكلة البمدث:

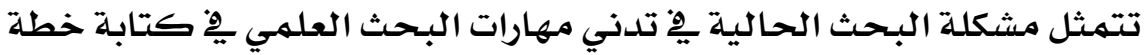

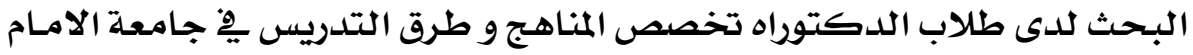

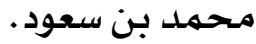

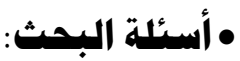

يسعى البـحث لإِجابة عن الأسئلة:

14 مـا مـهارات البـحث التي ينبغي مـراعاتها يخ فتابة خطة البـحث من قبل طـلاب

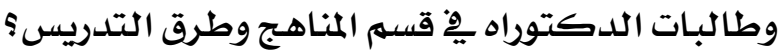

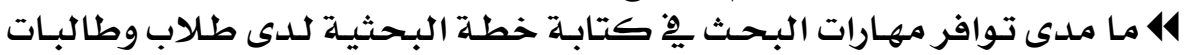

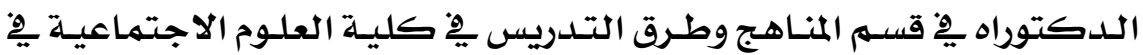

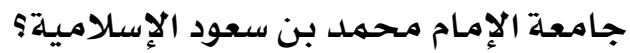

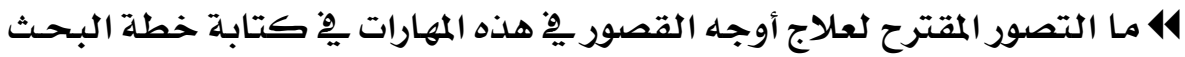

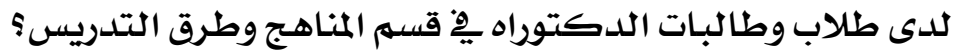

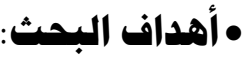

يهدف هذا البحث بوجـه عـام إلى تقـديهم تصـور مقترح لتتهيـة مهارات كتابـة

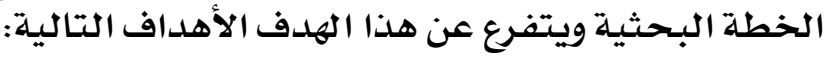

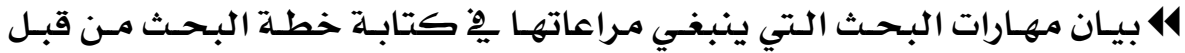

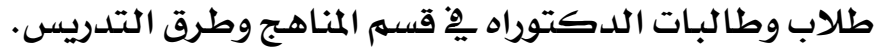

\section{9}




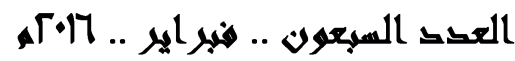

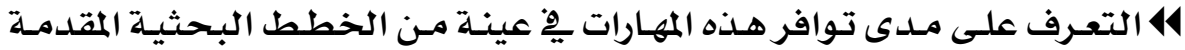

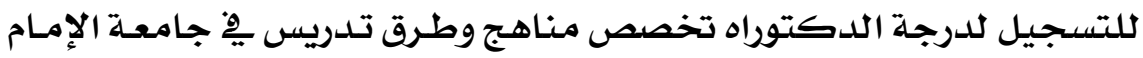

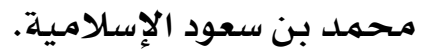

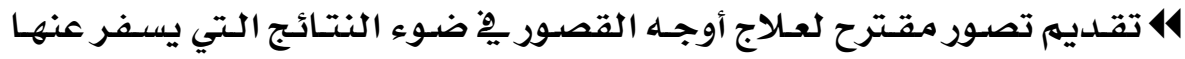

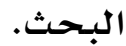

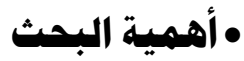
• الأهمية النظرية:

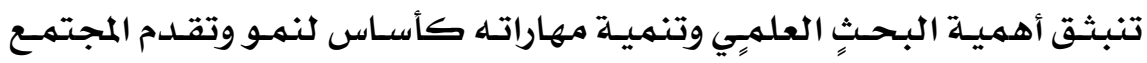
كما يقدم البحث إطارا نظريا يتناول مفهوم البحت البحث العلهي، وأهميته ومهاراته

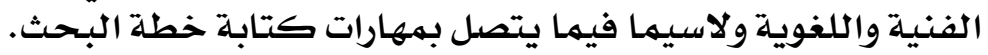

• الأهمية التطبيقية:

يمكن أن يفيد من أدوات البحث، وإجراءات ونتائج هذه البحث كل من:

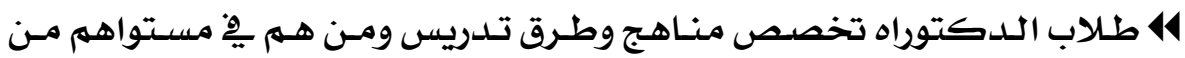

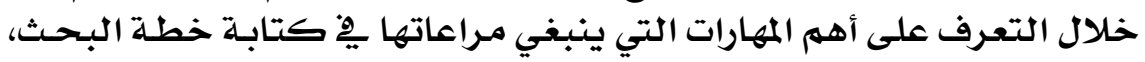

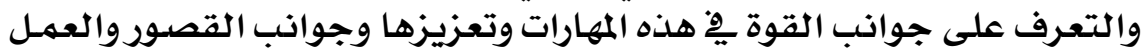

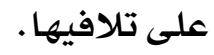

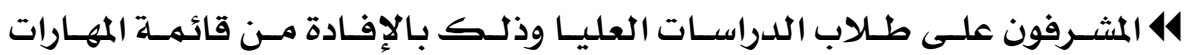

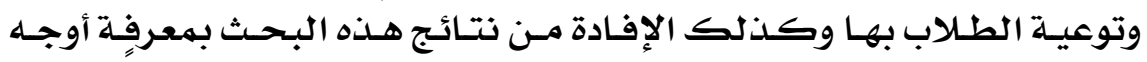

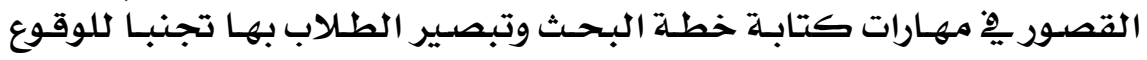
فيها. 414 الباحثون وذلك بإجراء بحوث ودراسـات ِِّ ضوء نتائج هذه البحث وبالإفـادة من إجراءاتها.

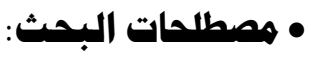
• التقويم:ان

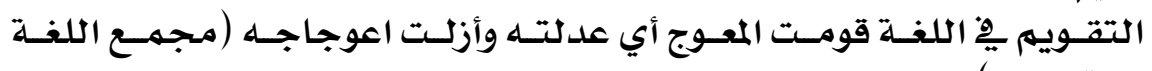

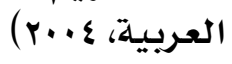

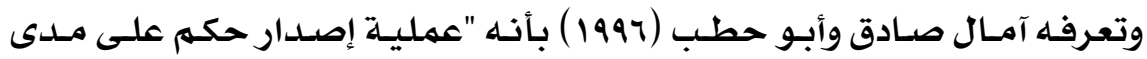

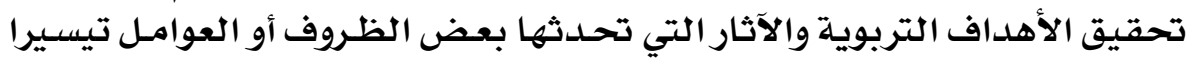

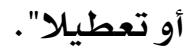

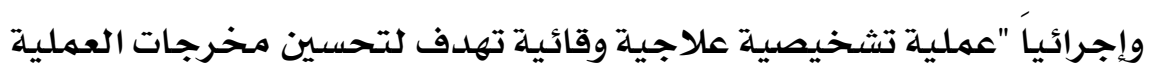
التربوية وتحديد جوانب القوة والضعف لعلاجها" .

\section{$r$.}


• البحث العلمي:وعيلة scientific research

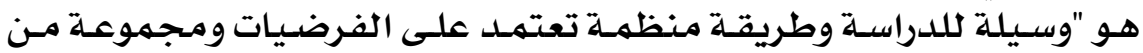

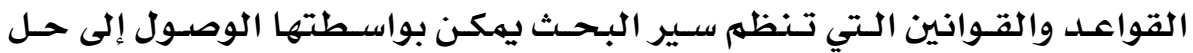

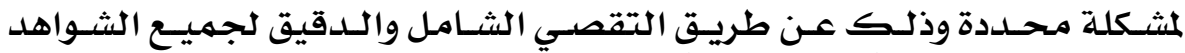
والأدلة ذات الصلة". (شاهين، • • ب)

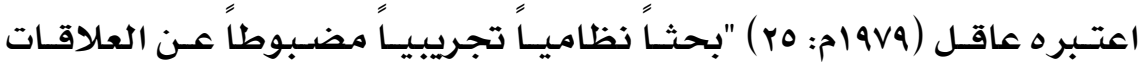

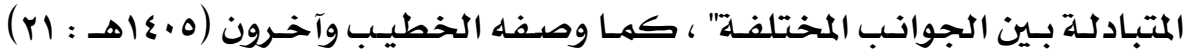

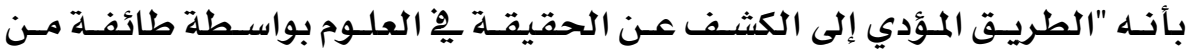

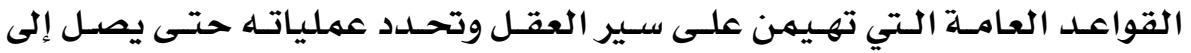

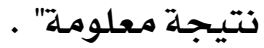

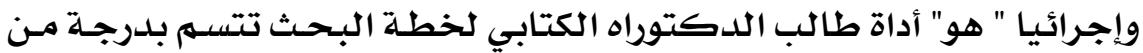

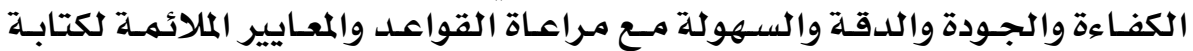

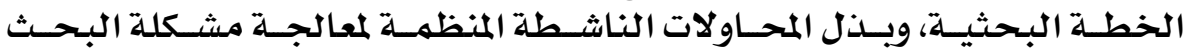

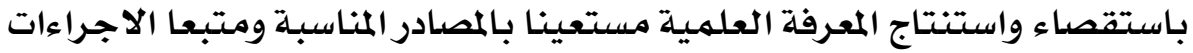

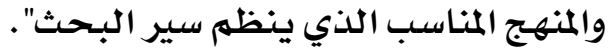

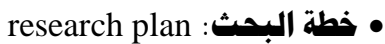

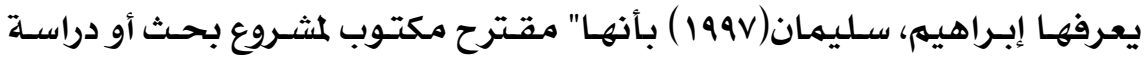

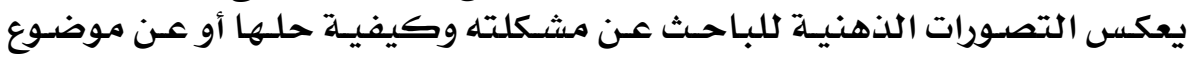

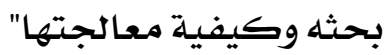

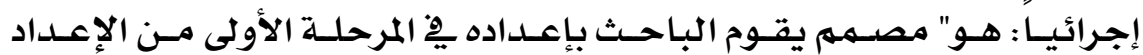

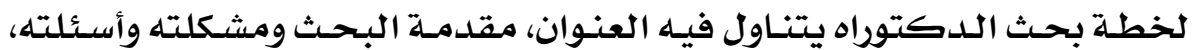

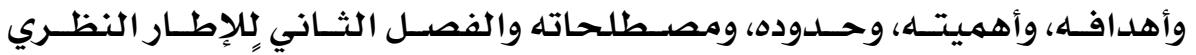

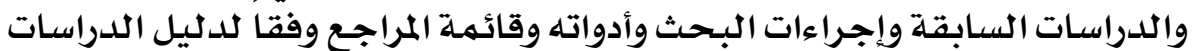

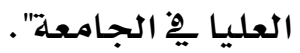

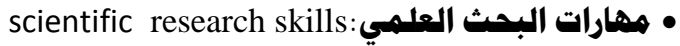
منامهارة من الفعل مهرَ، والمهارة الحذاق من الثيء والمـاهر الحساذق بكل عمل . بـن

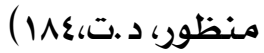

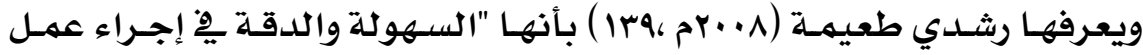

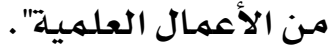

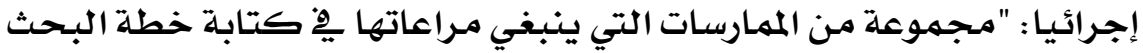

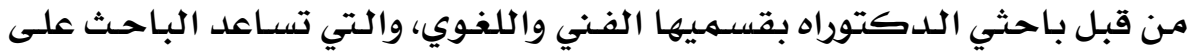
القيام بعمليات البحث بكفاءة عالية". 


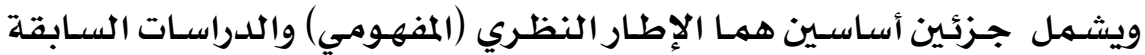

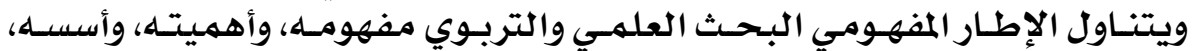

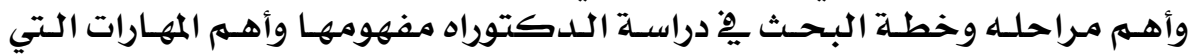

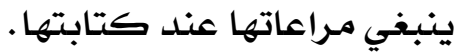

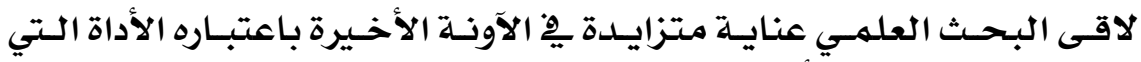

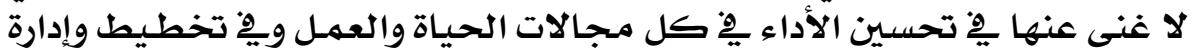

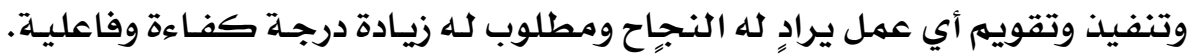

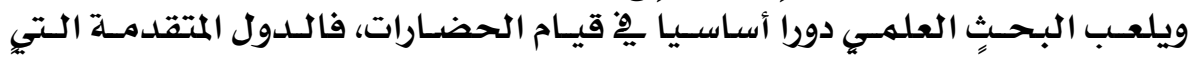

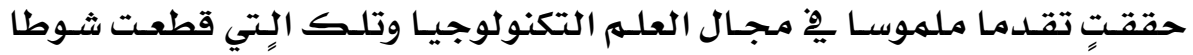

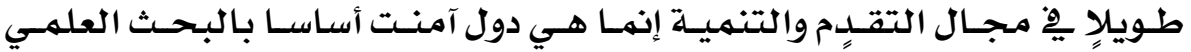

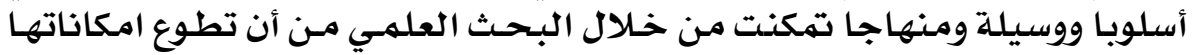

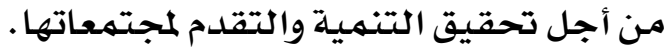

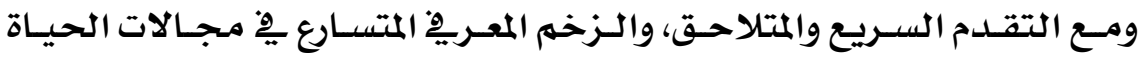

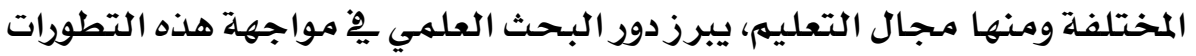

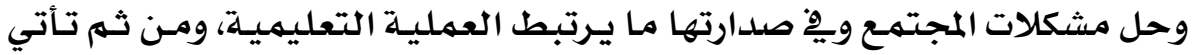

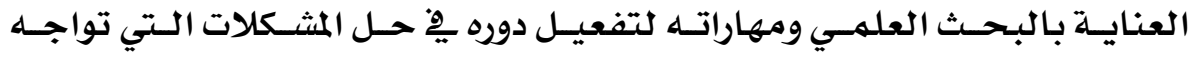

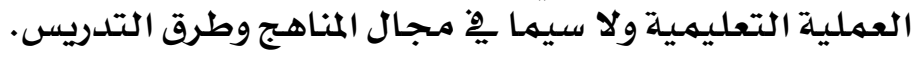

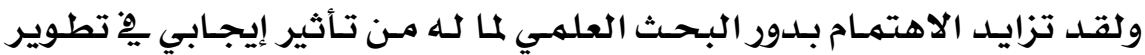

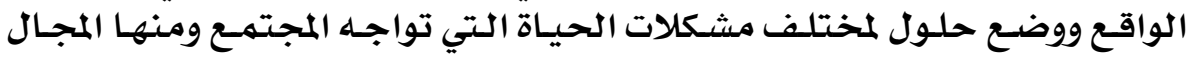

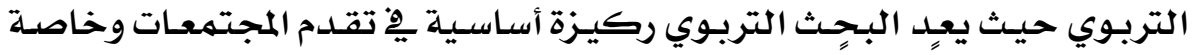

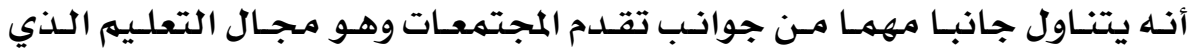

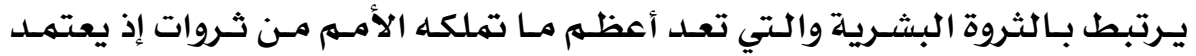

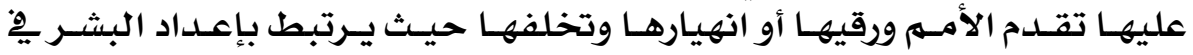
كافة مجالات الحياة وحل مشكلاتهاتهم.

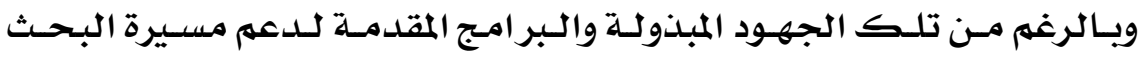

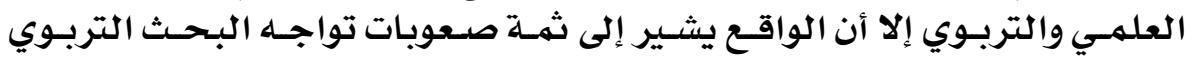

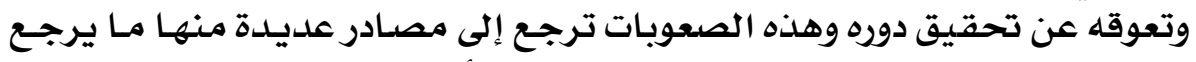

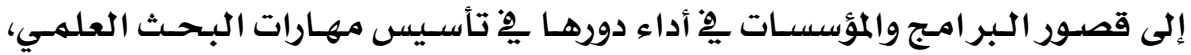

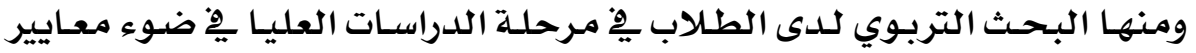

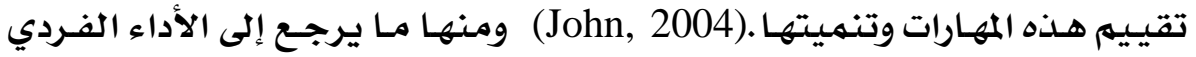

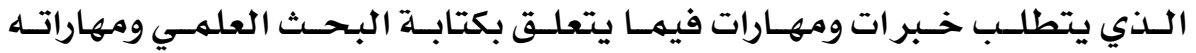


(James, etal, المختلفة ومراعاة الموضوعية ودقة الملاحظة واستخلاص النتائئ 2009), Oscar, 2009)

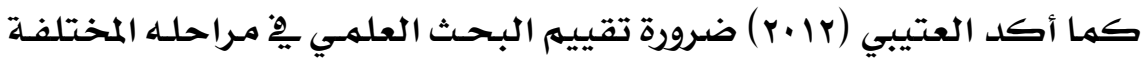

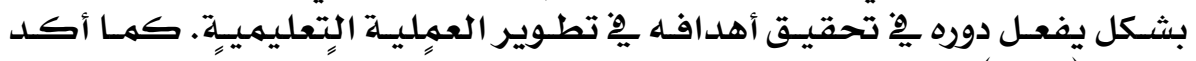

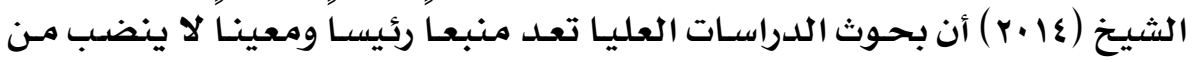

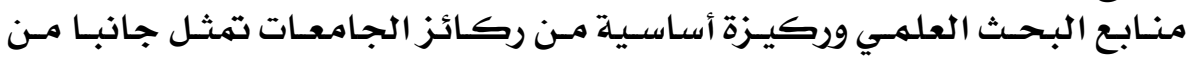

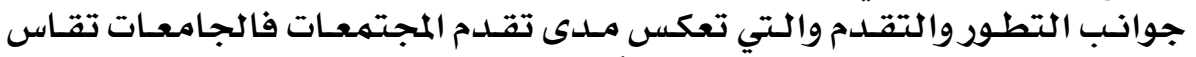

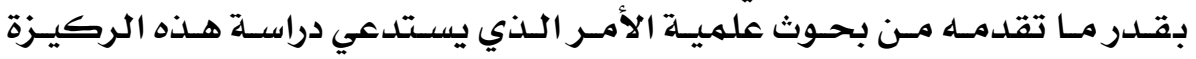

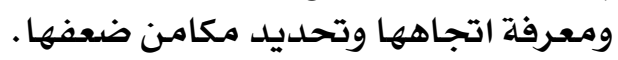

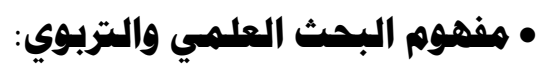

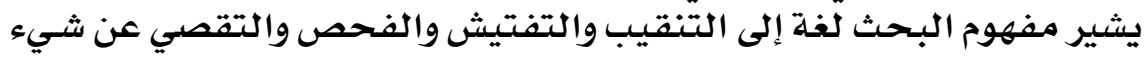

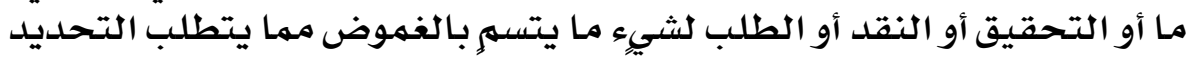

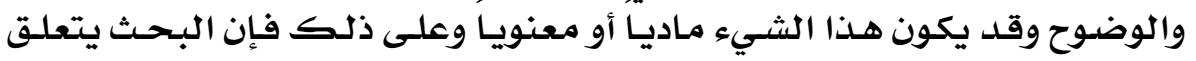

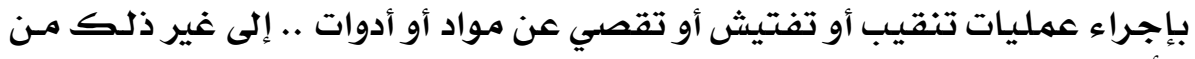

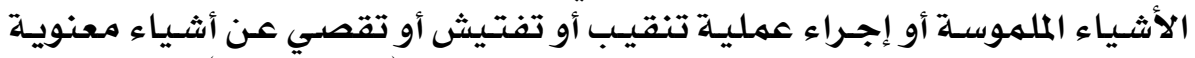

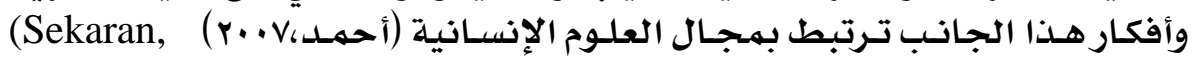
2006 ).

والبحث العلمي هو "نشاط منظم يقوم بـه الباحث أو مجموعة مـن البـاحة البـين

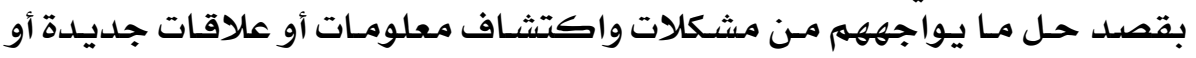

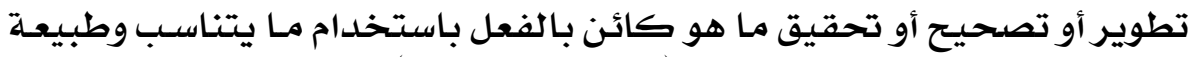

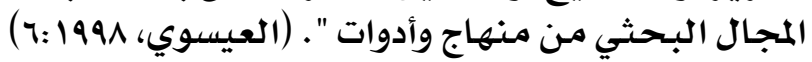

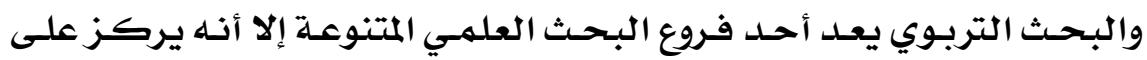

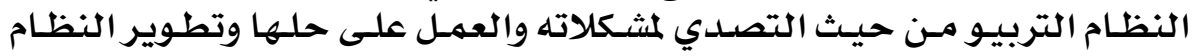

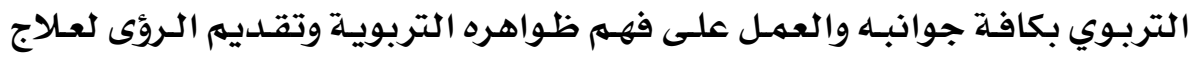
المشكلات التربوية الحالية والمستقبلية.

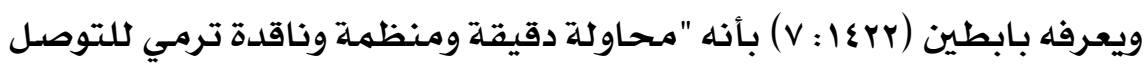

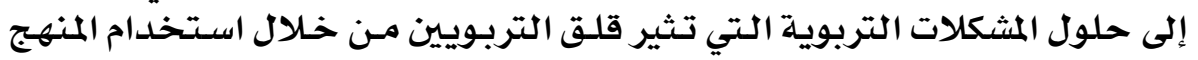

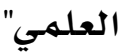

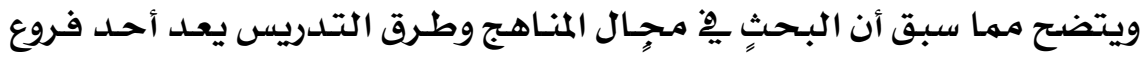

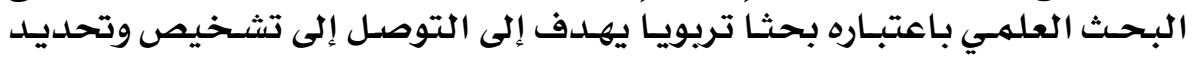

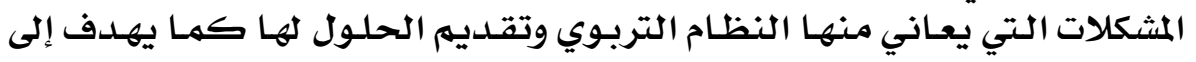
وصف الواقع وتحليله واكتشاف العلاقات بين المتغيرات المختلفة وتقديم معارف

\section{YY}




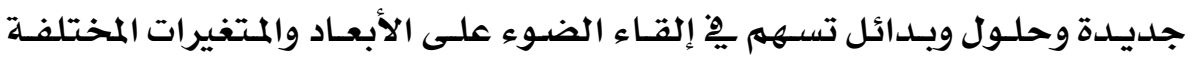
للعملية التربوية فيما يرتبط يو المناهج وطرق التباء الفرويس باتباع المنهج العلمي.

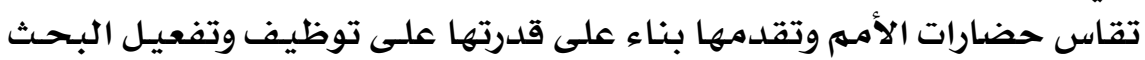

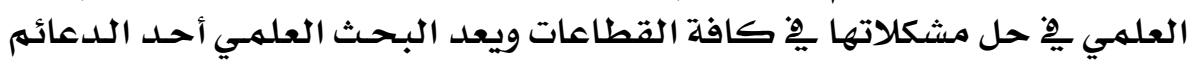

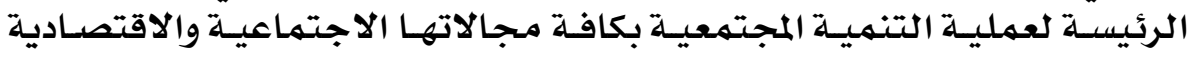

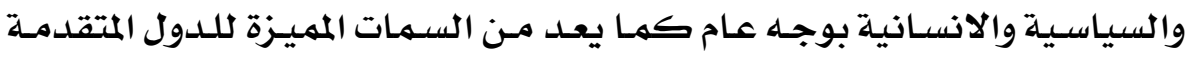

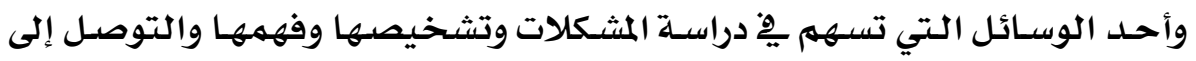
علاجها وإيجاد حلول لها.

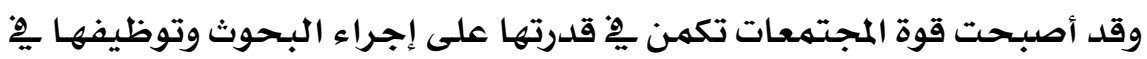

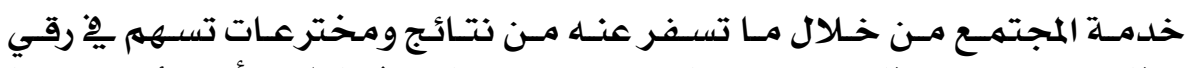

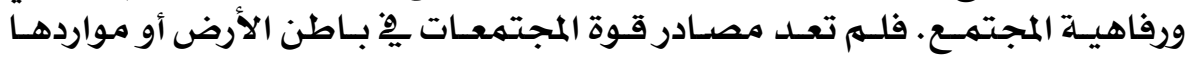

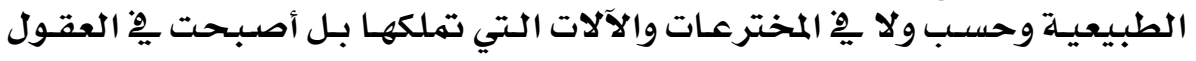

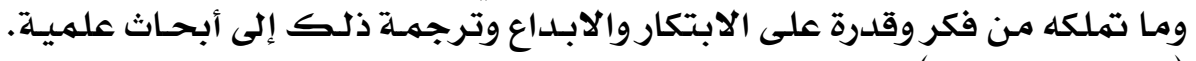

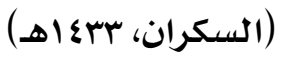

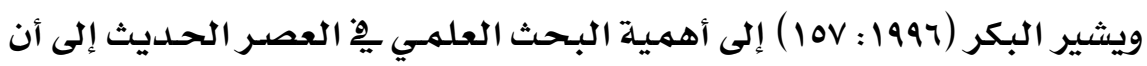

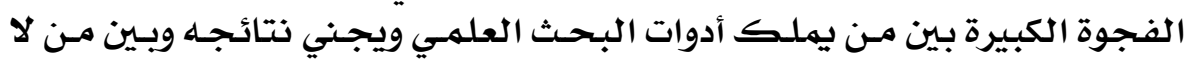

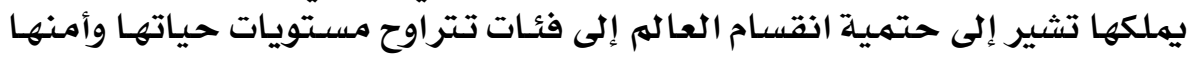

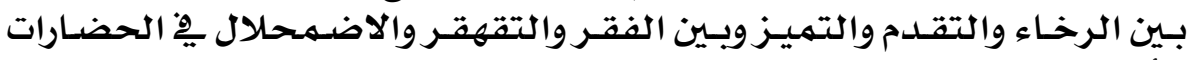
الأخرى.

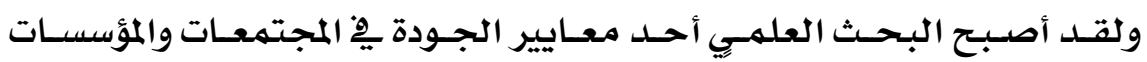

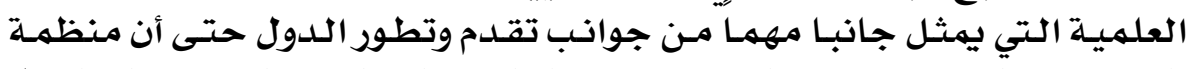

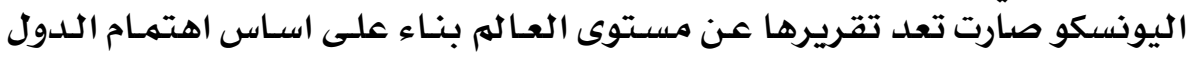

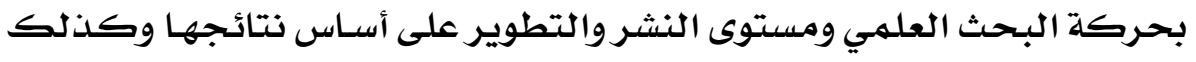

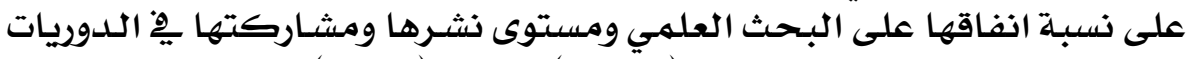

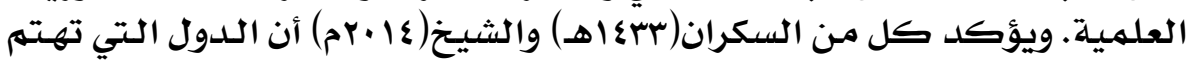

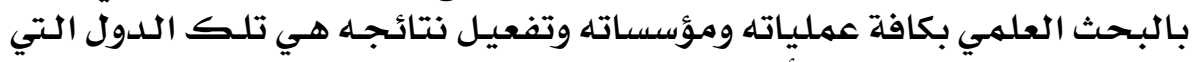

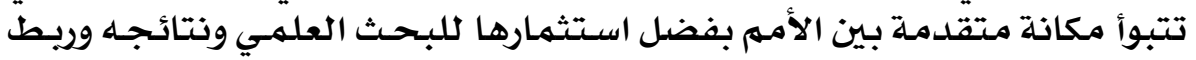
ذلك بتطوير المجتمع وتقدمدهـ.

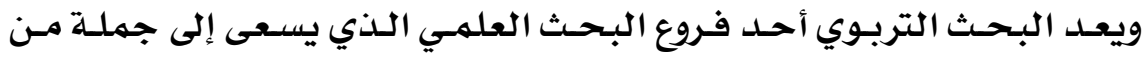

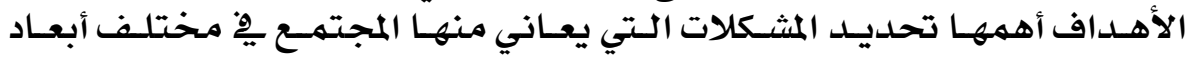

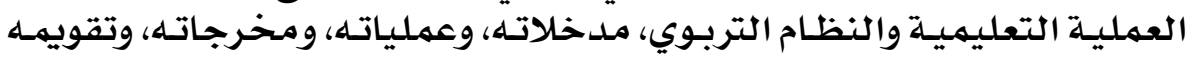

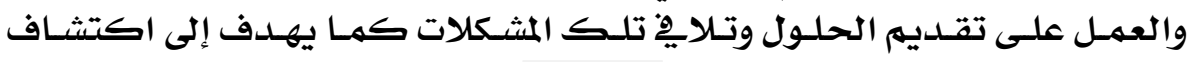

\section{Y $\varepsilon$}




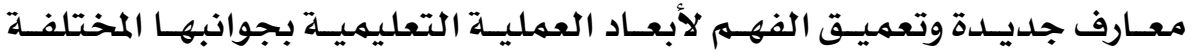

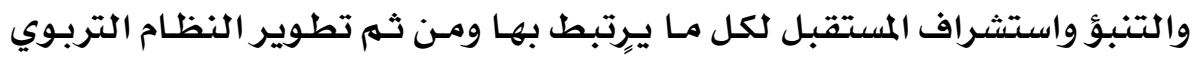

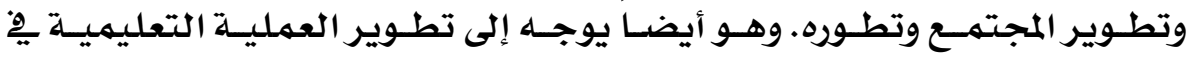

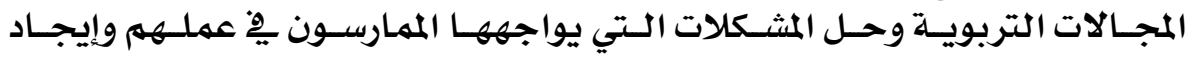

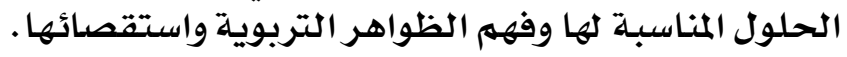

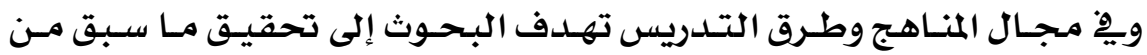

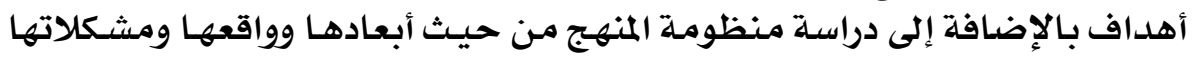

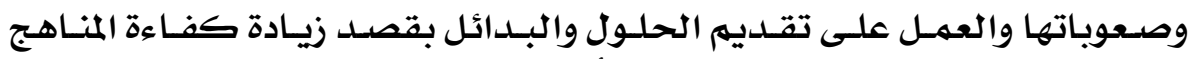

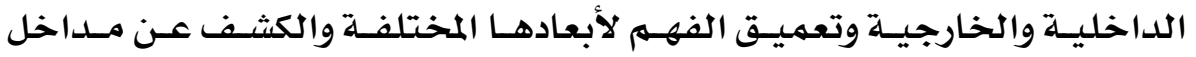

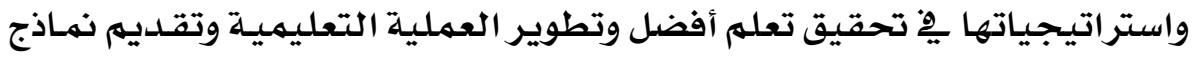

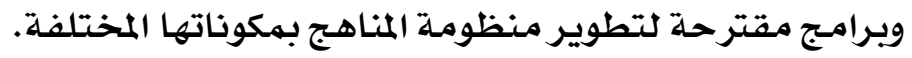

وتعـد بحـوث المنـاهـج وطـرق التـدريس نهطـا مـن البـحث التربـوي التي يجريهـا

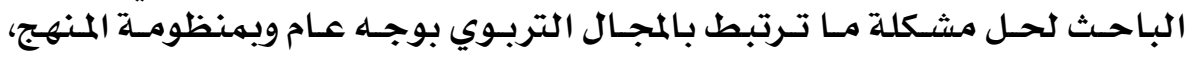

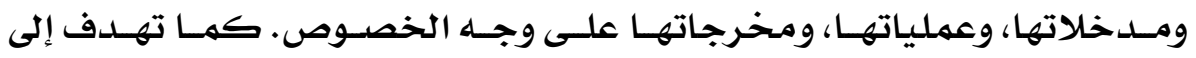

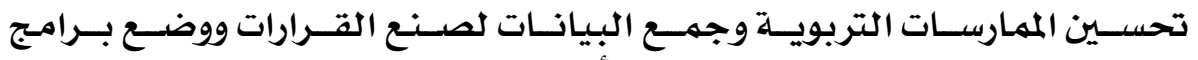

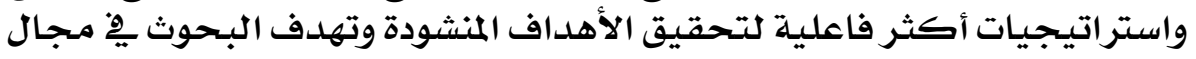
المناهـج وطرق التدريس إلى

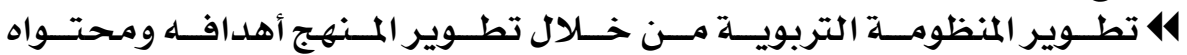

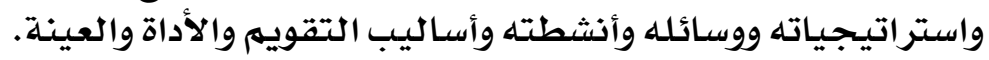

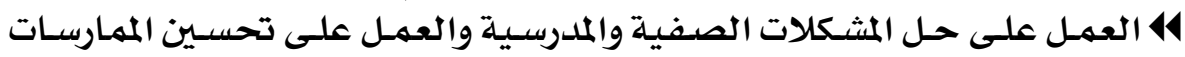

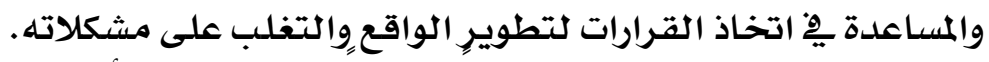

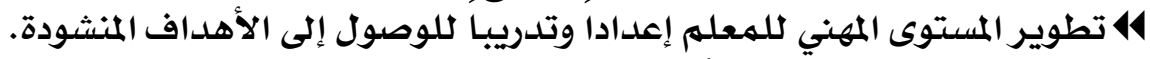

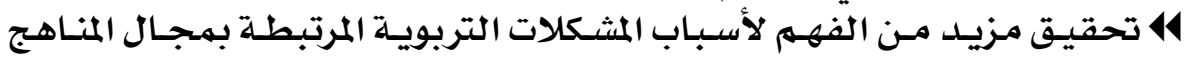
وطرق التدريس.

14 العمل على تحقيق الأهداف المرجوة مـن خـلال تنهميـة الجـانب المعـريخ والمهاري

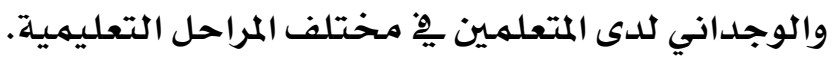

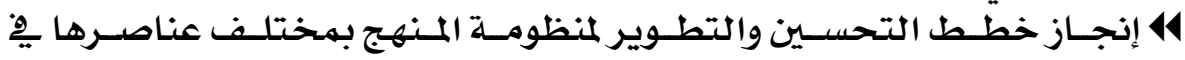
الحاضدر والمستتقبل.

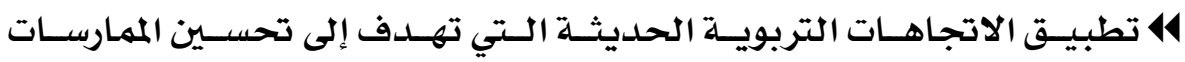

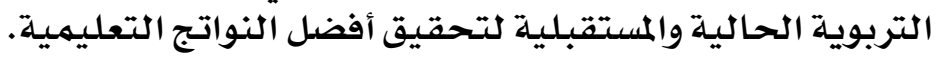

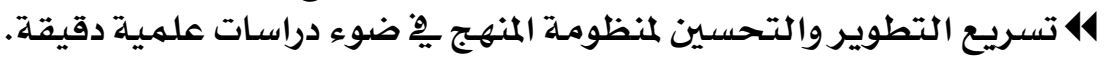

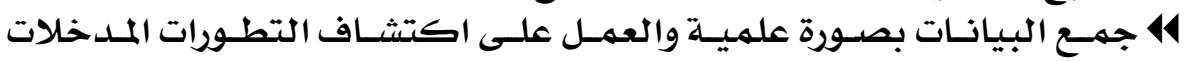

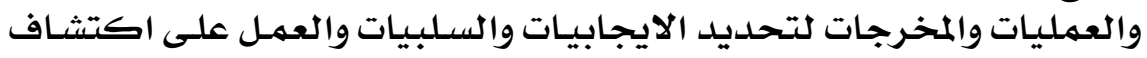

المشكلات بصورة مبتكرة وتهلافيها .

\section{Y०}




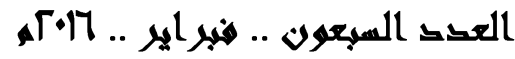

14 تقويم فاعلية استراتيجيات حديثة وأنشطة ووسائل تعليميـة صـادقة وتحسين الماين

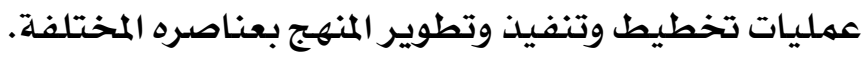

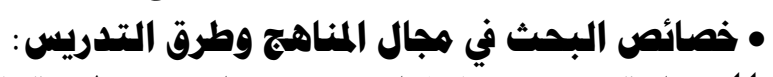

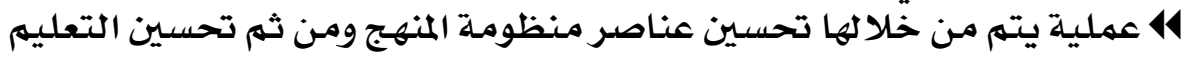
وتحقيق نواتجه المرجوة.

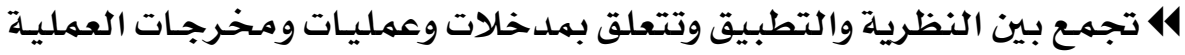

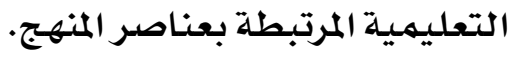

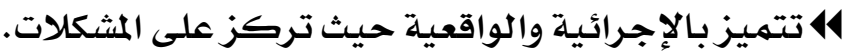

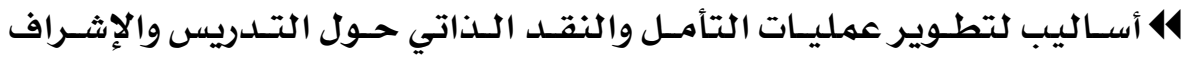
والتقويم والتدريب. 414 تقوم على التخطيط واتباع الطرائق العلميـة لتحقيق الفهـم وتعميقه وحل المشكلات واتخاذ القرارات.

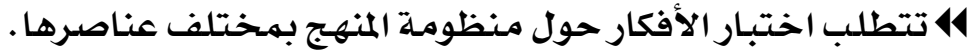

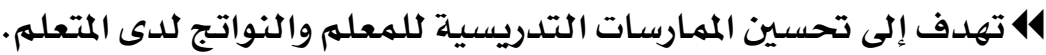

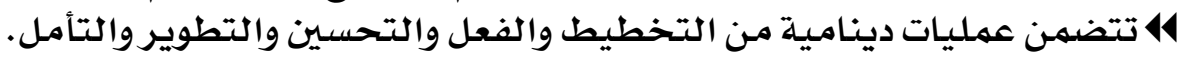

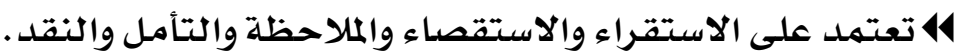

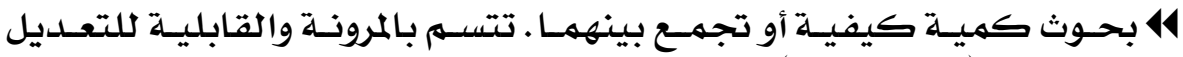

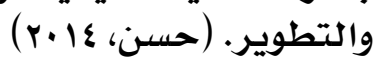

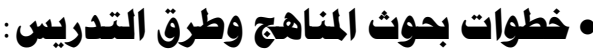

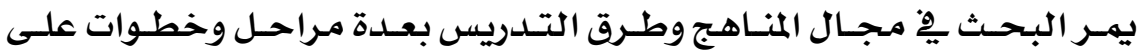

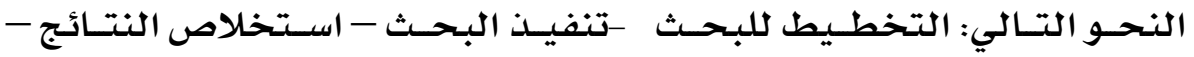
كتابة التقارير.

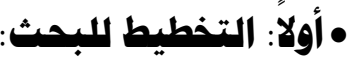

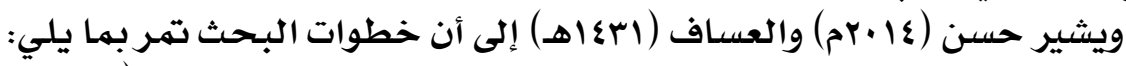

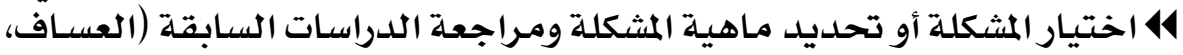

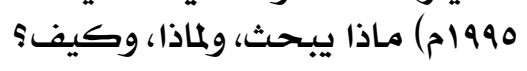

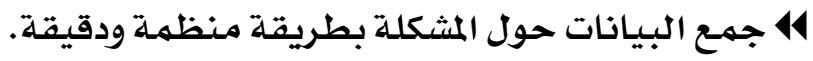

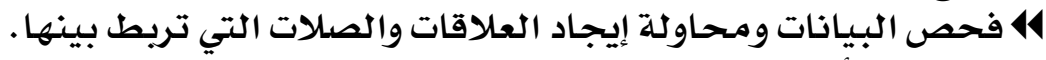

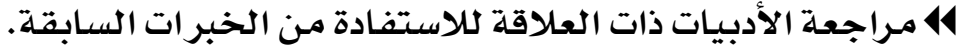

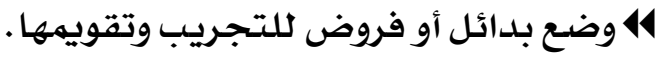

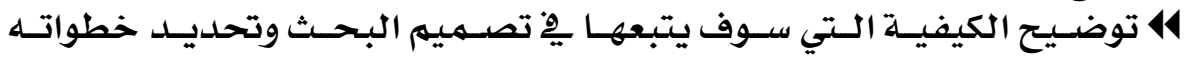

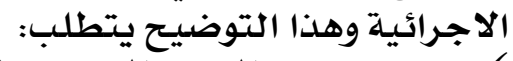

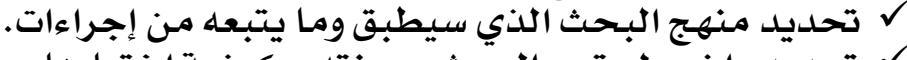

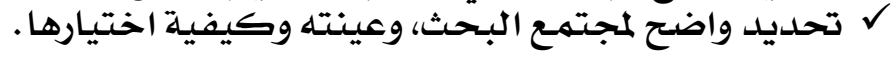

\section{Y7}




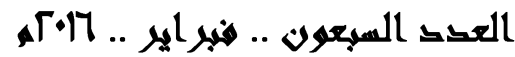

$$
\text { ل } \checkmark
$$

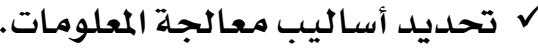

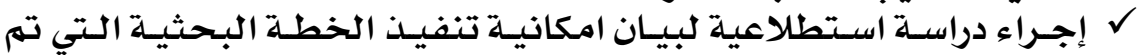

تخطيطها.

وتمر عملية التخطيط بالمراحل التالية:

44 التأمل للواقع.

414 الحوار حول هذا التأل الواقع ومحاولة إثباته بالمصادر المختلفة والأدلة.

14 ت تحديد المشكلة.

14 وضع خطة للبحث.

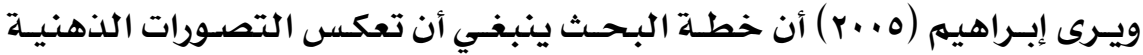

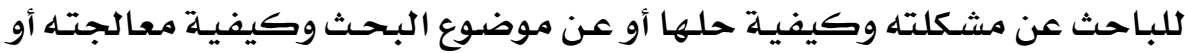

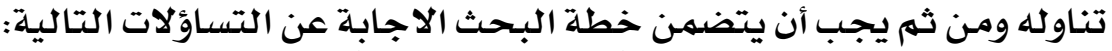

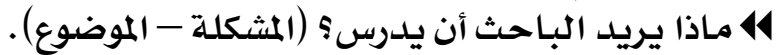

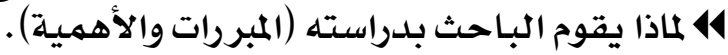
14 كيف سيقوم الباحث بحل المشكلة (المنهجية).

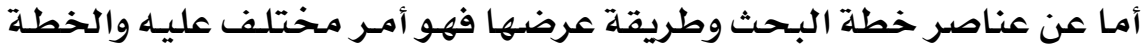

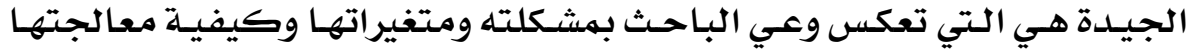

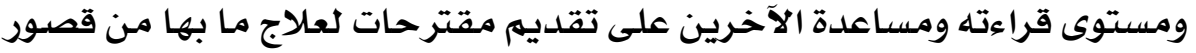

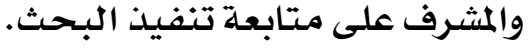

\section{• مناصر الخطة وههارات كتابتها:}

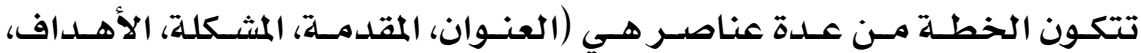

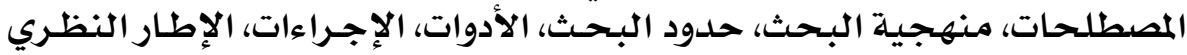

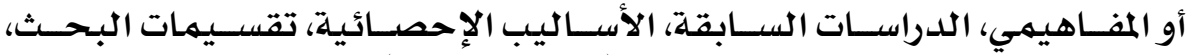

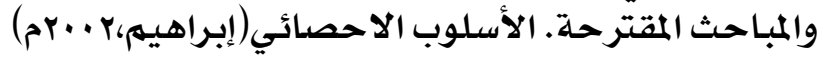

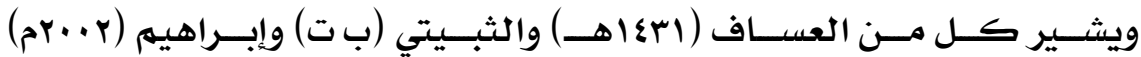

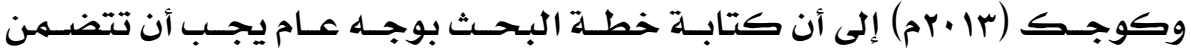

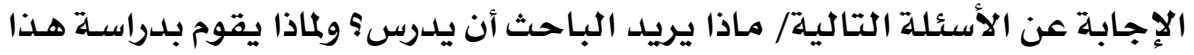

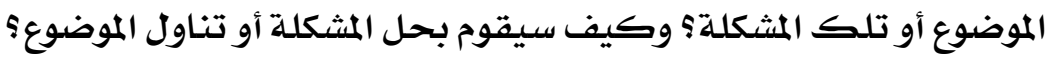

وفيما يرتبط بعناصر الخطة تتطلب اتقان عدد من المهارات أهمها ما يلي:

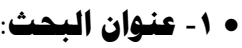
وهو الواجهة التي تبرز موضوع البحث ونوعه وأهدافه ومتغيراته ومهاراته هي:

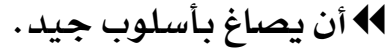
44 أن يعبر عن موضوع البحث بوضوح.

\section{YV}




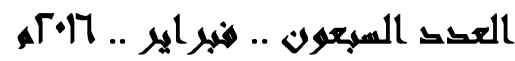

$$
1411 \text { 14 } 11 \text { أن } 14
$$

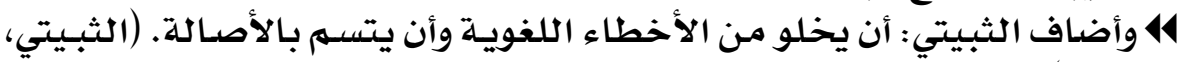

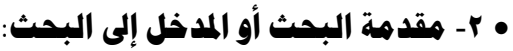

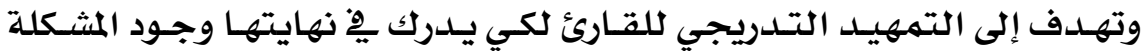

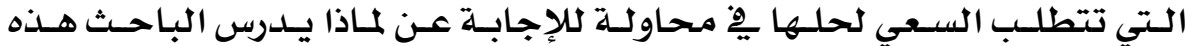

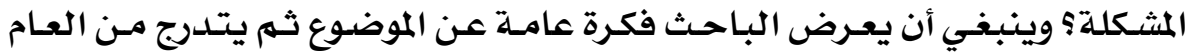

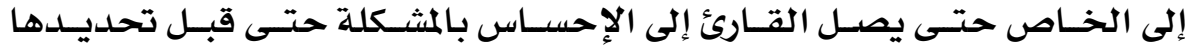

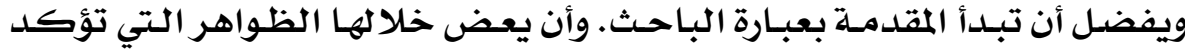

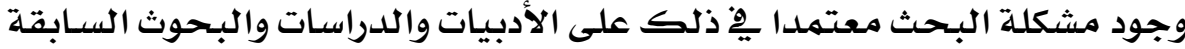

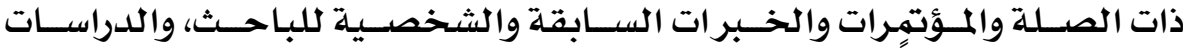

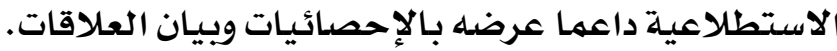

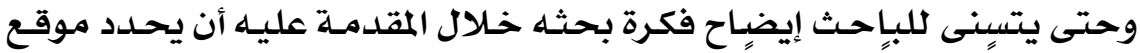

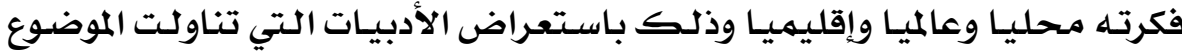
وتؤكد أهميته محليا.

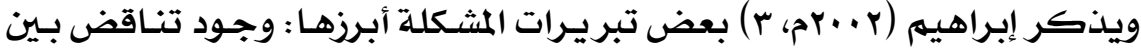

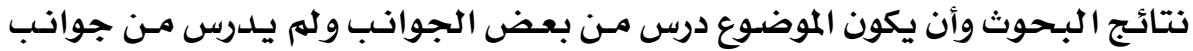

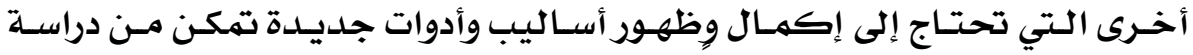

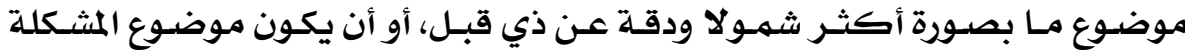

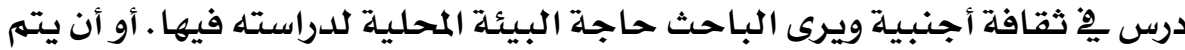

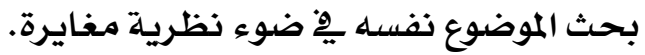

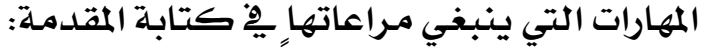

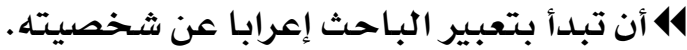

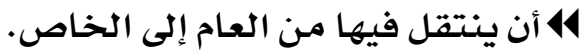

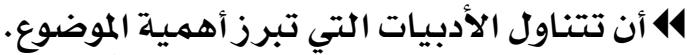

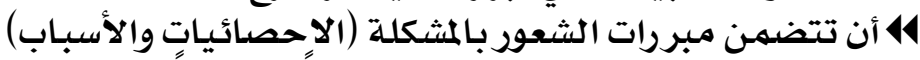

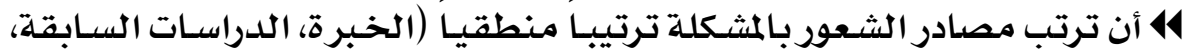

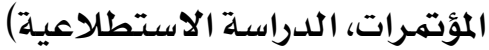

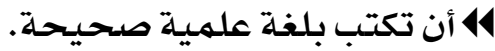


العقى السبعون .. هنبر اير .. 17.

14 أن تظهر شخصية الباحث يِّ الكتابة.

• ب- تمديد المشكلة:

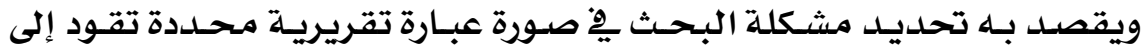

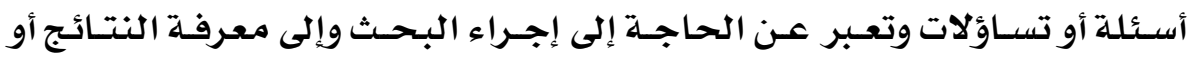

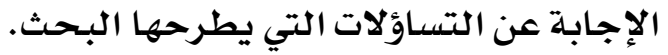

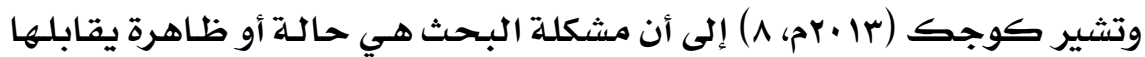

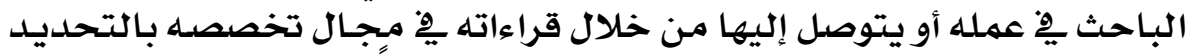

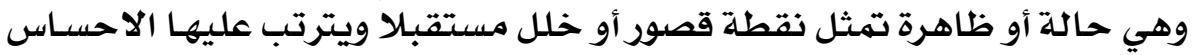

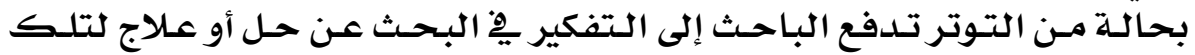

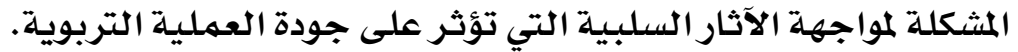

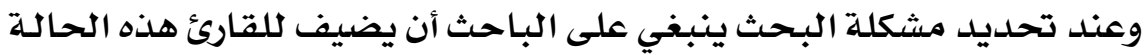

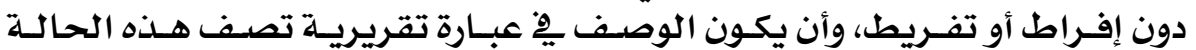

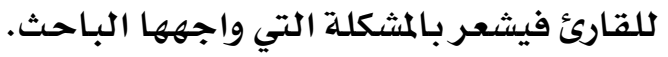
ومن أهم المهارات التي ينبغي مـراعاتها يِّ تحديد المثكلة ما يلي:

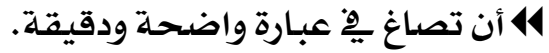

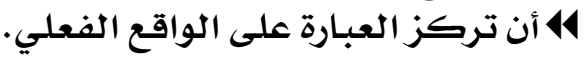
14 أن ترتبط بعنوان البحث. 141 أن أن تفضي لأسئلة البحثث.

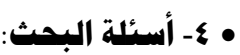

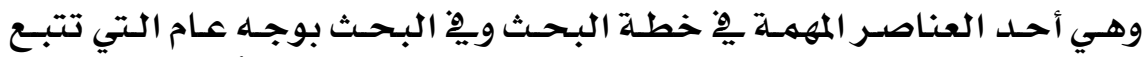

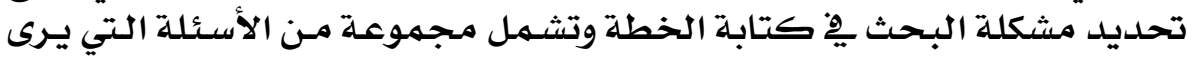

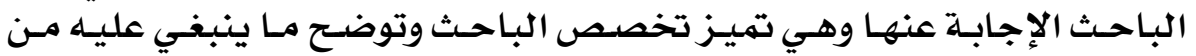

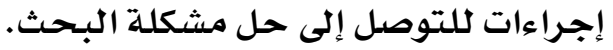

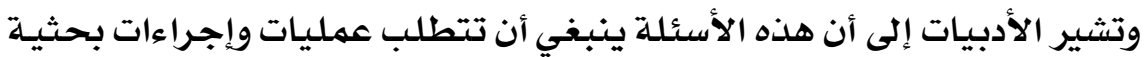

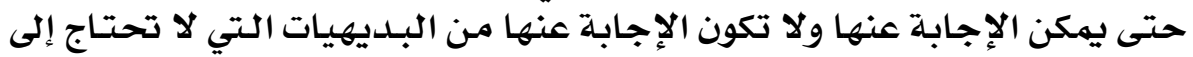

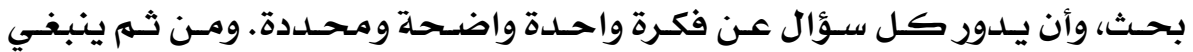

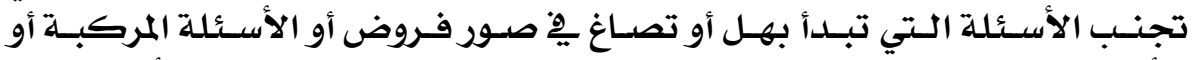

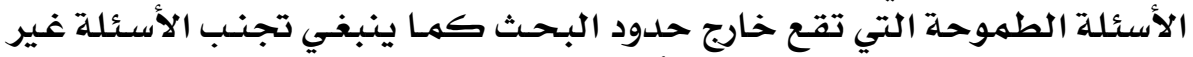

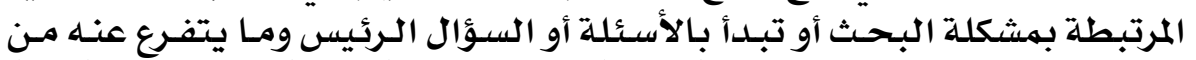

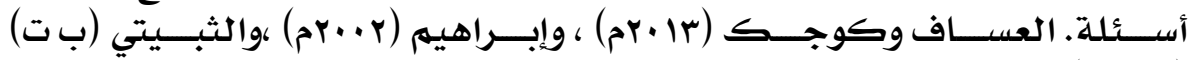
(مr...)

\section{pq}


العقد المبعهون .. هبراير ..

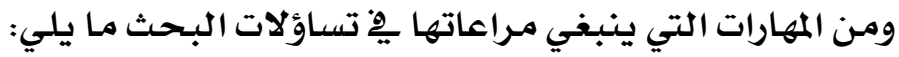

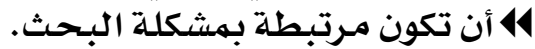

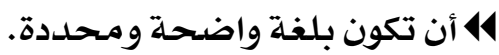

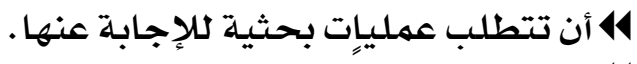
14 - 14 أن ترتب منطقياً.

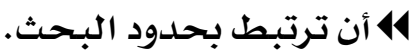

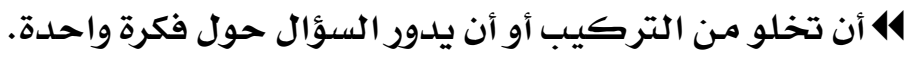

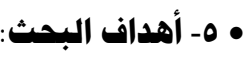

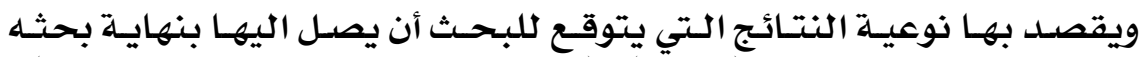

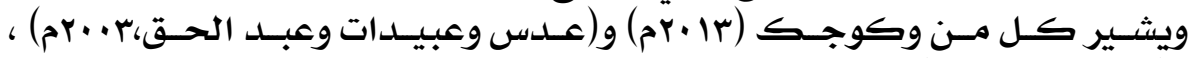

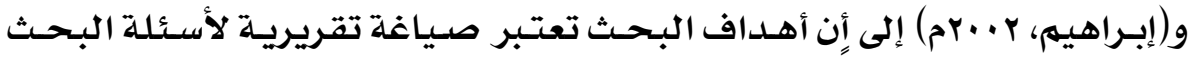

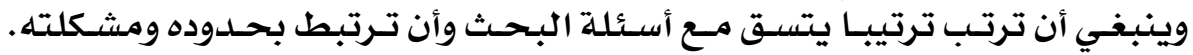

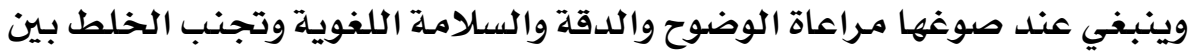
الأهداف والاجراءات أو الخلط بينها وبين الأهمية.

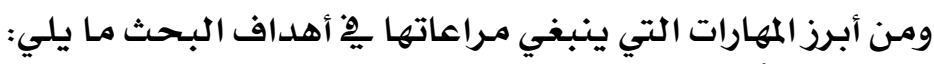

14 أن ترتبط بأسئلة البحث البحث.

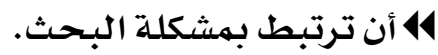
14 أن تكون دقيقة قابلة للتحقيق.

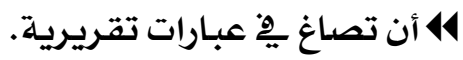
414 أن ترتبط بنتائج البحث المتوقعة

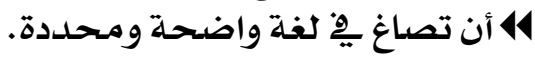
أن أن تخلو من الخلط بين الهين الهدف والأهمية.

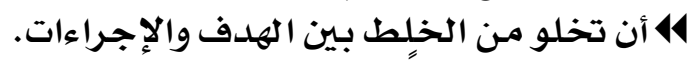

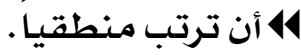

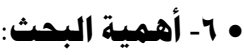

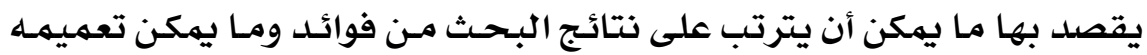

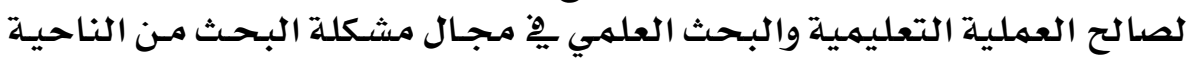

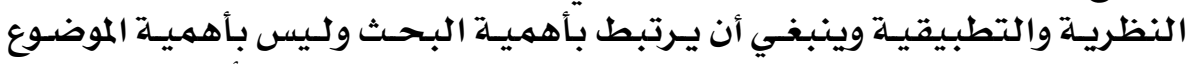

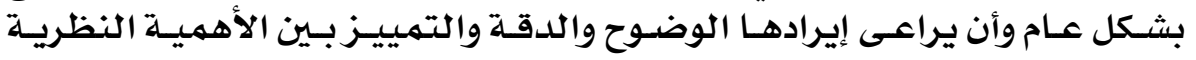

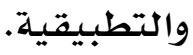

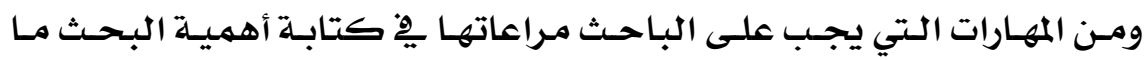
يلي: ترن 414

\section{$r$}


414 أن تصاغ يُّ لغة واضحة ومحددة. 14 أن يميز يِّ صوغها بين الأهمية النظرية والأهمية التطبيقية. ه أن تتجنب الخلط بين الأهمية النظرية والأهمية التطبية التطية.

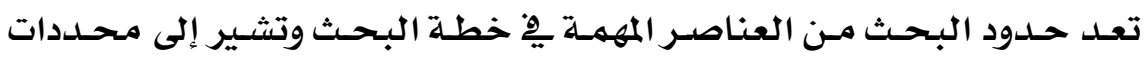

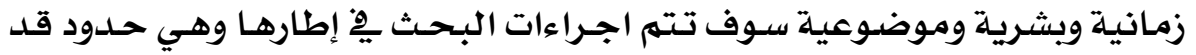

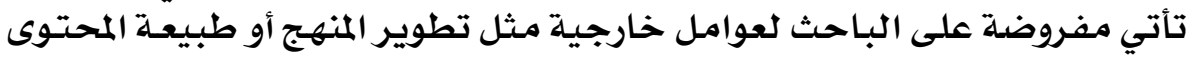

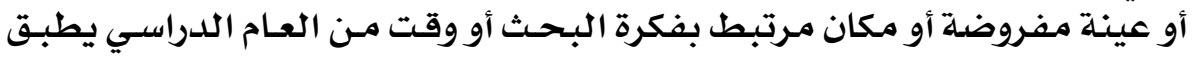

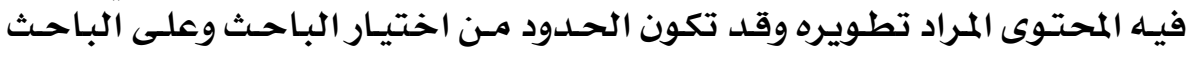

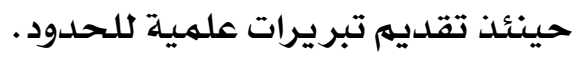

ومن المهارات التي يجب على الباحث مراعاتها يِّ كتابة حدود البحثث ما يلي:

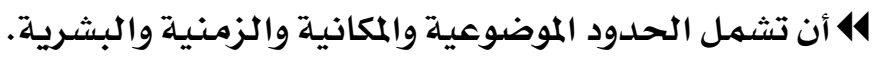

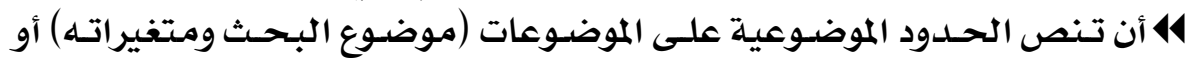

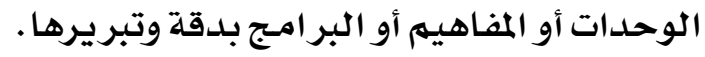

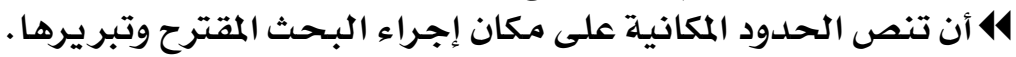

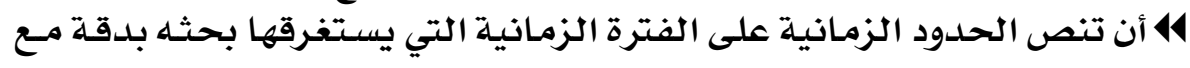
انتبرير.

44 أن ينص الحير الحد البشري على من سيطبق عليهم البـحث بـدقة وتبر بيره.

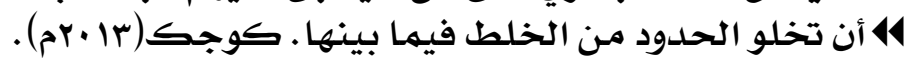

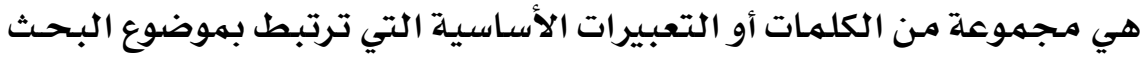

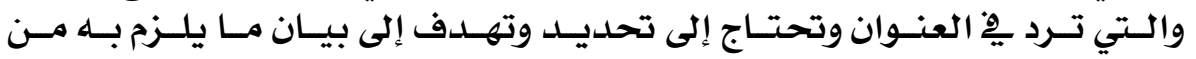

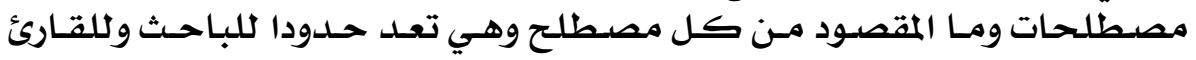

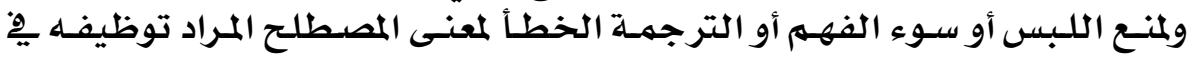

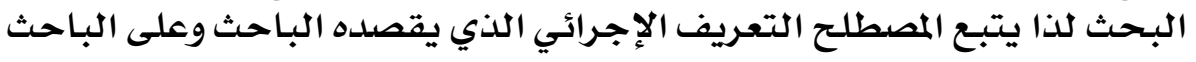

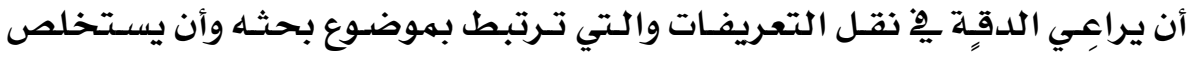

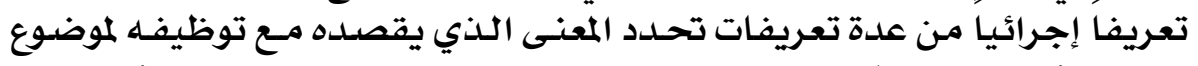

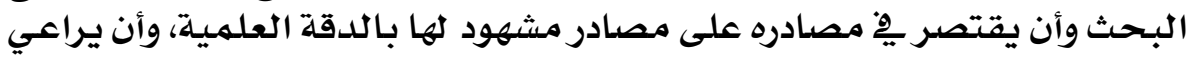

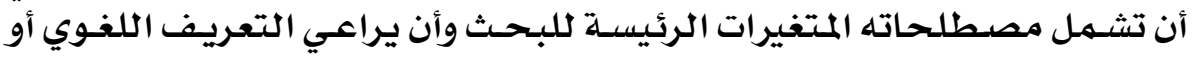

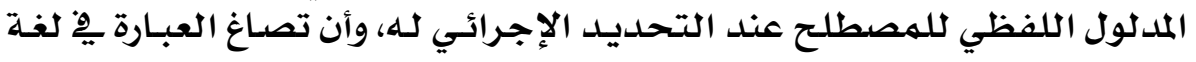
واضحة محددة.

ومن المهارات التي يجـب على الباحث مـراعاتها ِِِ كتابـة مصطلحات البـحث ما يلي: ومن:

\section{r}




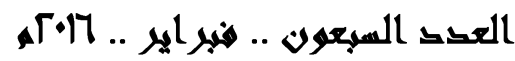

414 أن تشمل مصطلحات البحث متغيرات البحث التي تحتاج إلى تعريف.

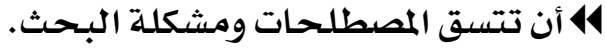

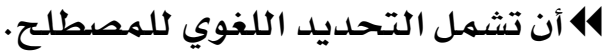

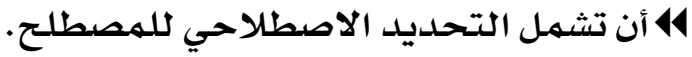

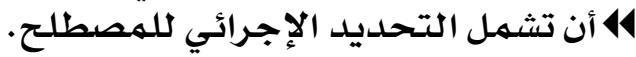

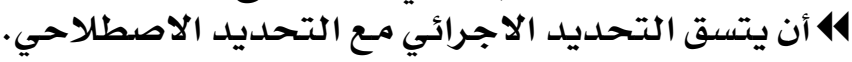

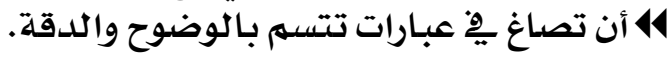

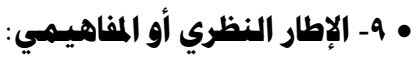

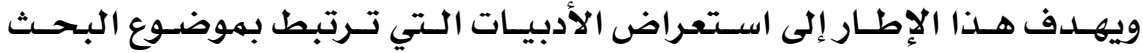

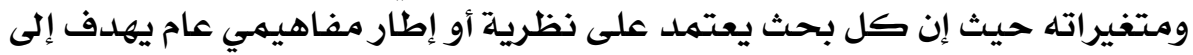

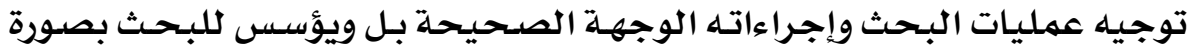

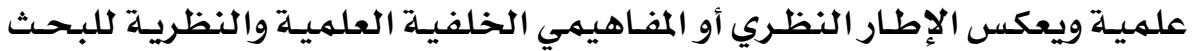

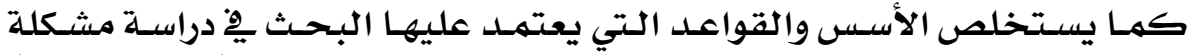

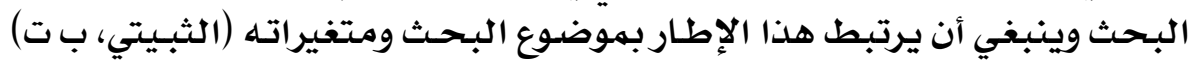

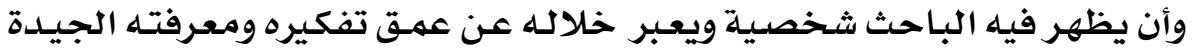

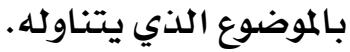
وهن أهم المهارات التي ينبغي مراعاتهاتها ما يلي:

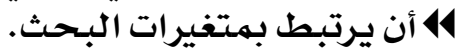

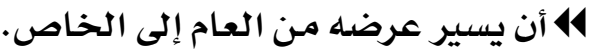

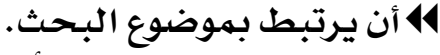
14 أن يعتمد على المصادر الأساسية ما أمكن.

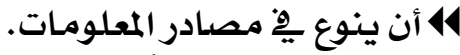
414 أن يتجنب إيراد الأفكار المتناقضة 14 ال أن يعكس شخصية الباحث.

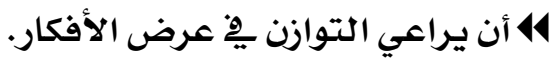

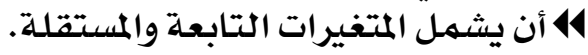

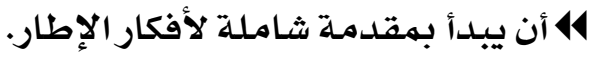

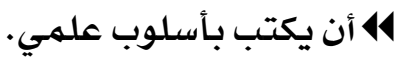

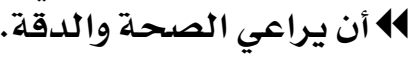
14 أن يربط السابق بالكاحق.

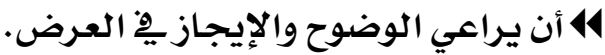

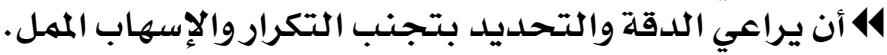

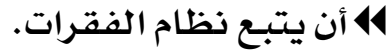
414 أن يستخدم علامات الترقيم بصورة صحيحة.

\section{rY}




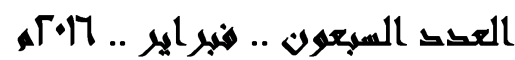

41 أن يختم (الفصل) بتعقيب يستخلص أفكاره.

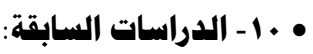

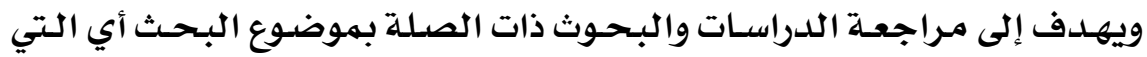

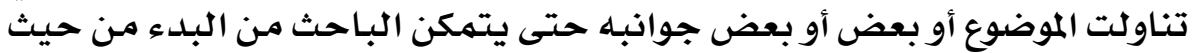
انتهى الآخرون من الباحثين وأن يتجنب قصور ألتور الآخرين.

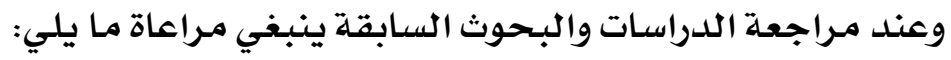

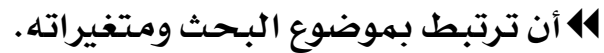

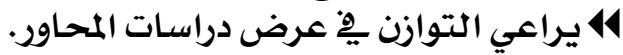

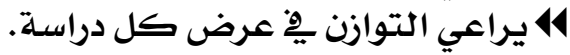

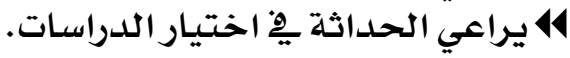

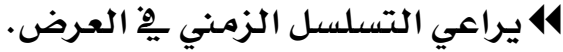

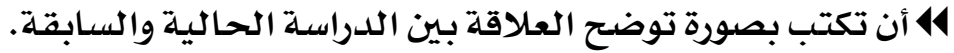

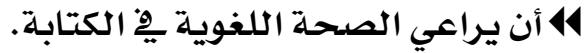

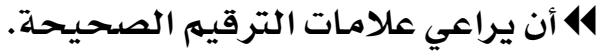

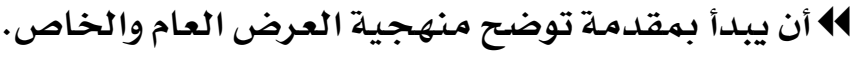

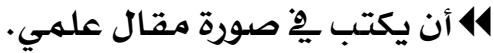
14 أن يعقب على كل كل محور. 141 أن يعقب على كل كل الدراسات ككل. • 11 - هنهج البحث:

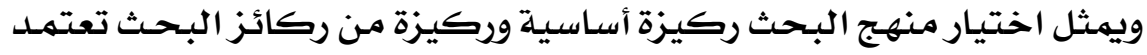

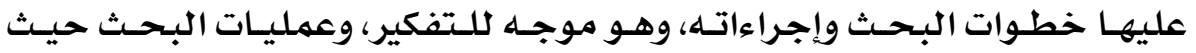

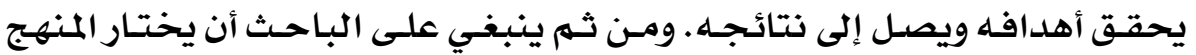

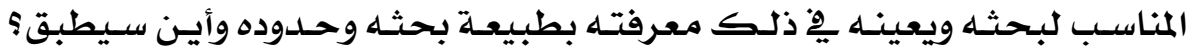

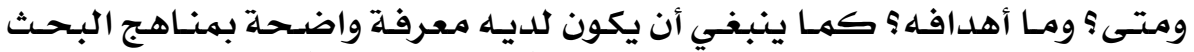

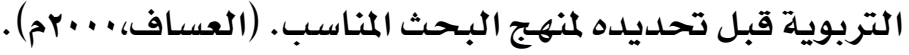
ولكتابة منهج البحث عدة مهارات ينبغي مـراعاتها نوردها فيما يلي: 14 أن يحلدد المنهج المناسبت البحت

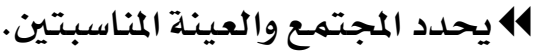

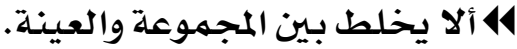

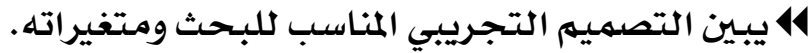

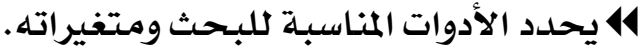

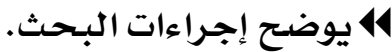
14 يربط الإجراءات بأسئلة البـحث.

\section{Mr}


العقى السهبعرن .. همبر اير ..

41 أن يراعي الدقة اللغوية ِِّ كتابة منهجية البحثث.

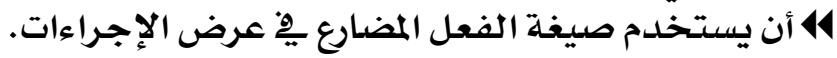

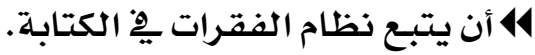

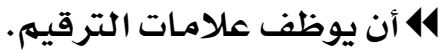

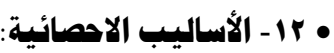

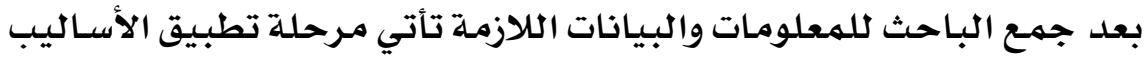

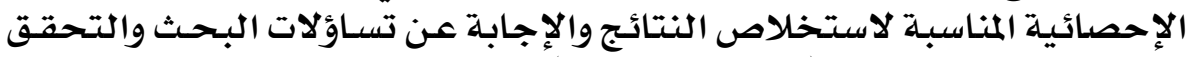

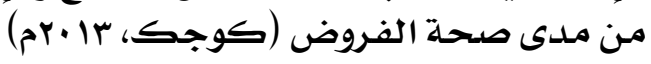

ولتحقيق هذا الهدف ينبغي مـراعاة ما يلي:

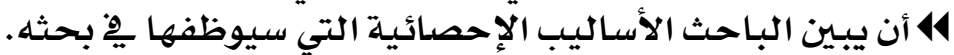

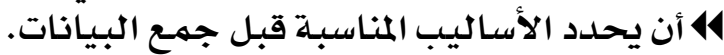

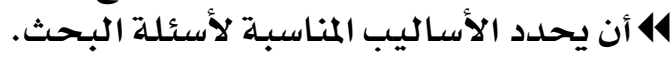

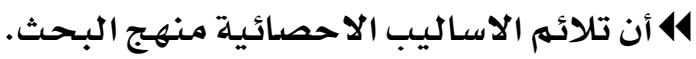

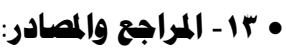

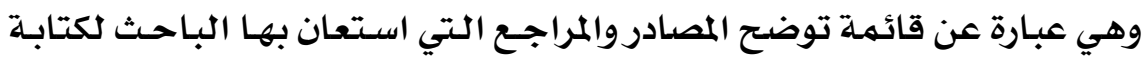

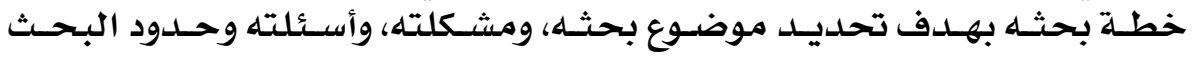

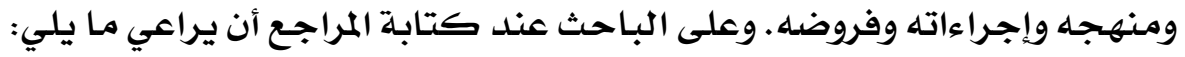

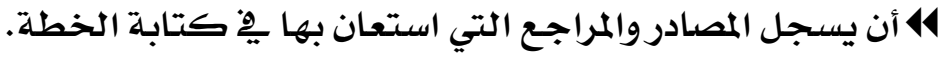

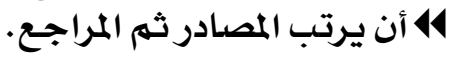

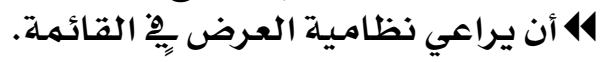

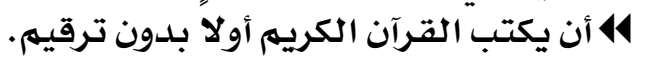

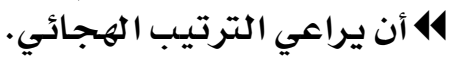

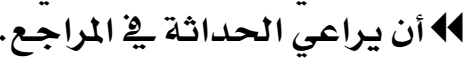

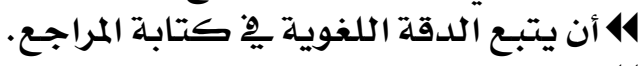

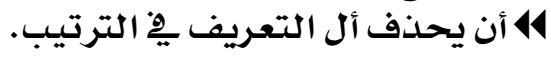

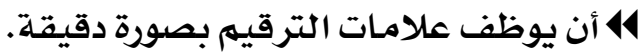

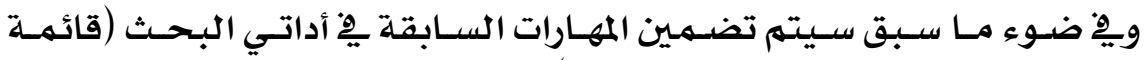

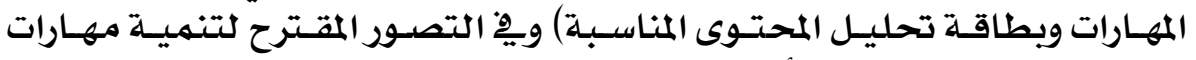

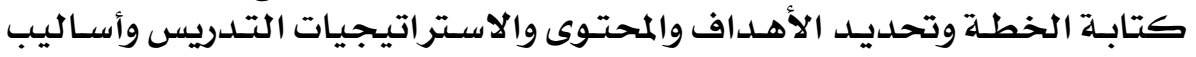
التقويم له.

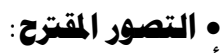 أسس التصور المقترح:} يقوم التصور المقترح على الأسس التالية:

\section{r $\varepsilon$}




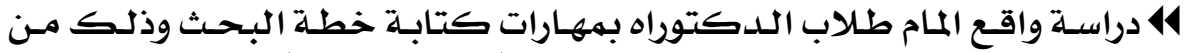

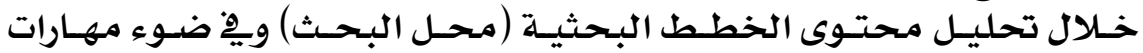

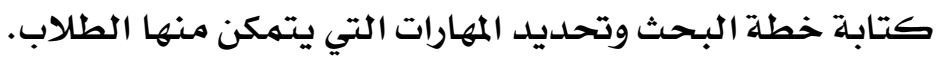

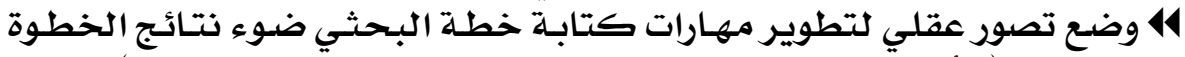

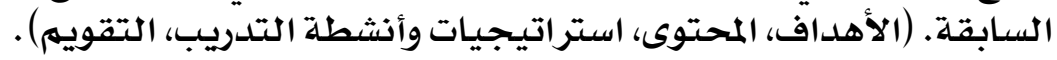

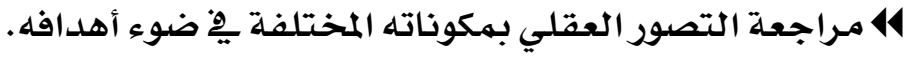

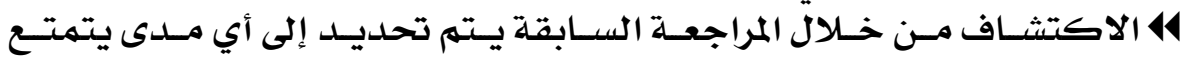

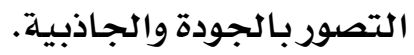

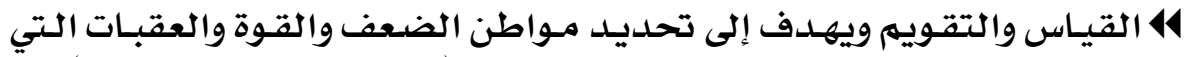
يمكن أن تواجه التصور والبدائل للتغلب عليها تحوفي (Hou \& Kuo-En, 2007).

خطوات عمل التصور المقترح:

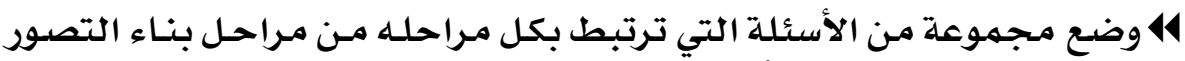

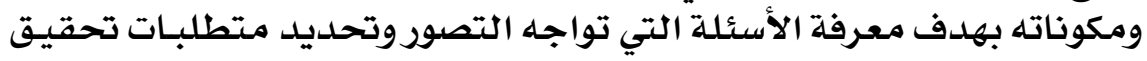

$$
\text { كل جانب. }
$$

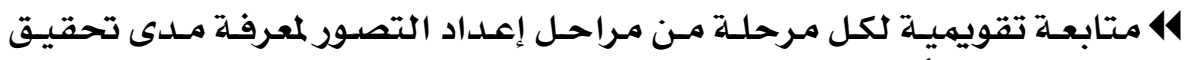

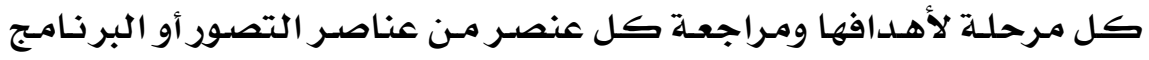

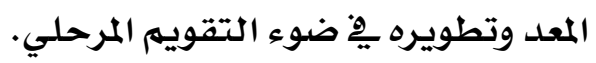

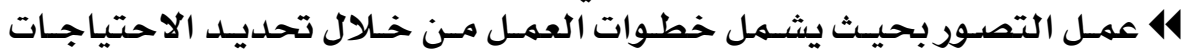

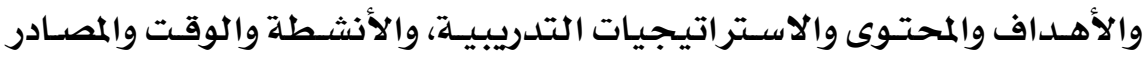

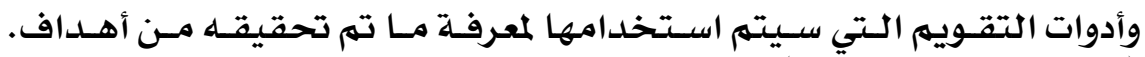
(http:www.intel.com)

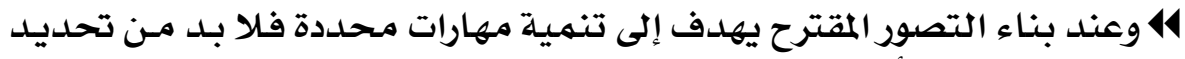

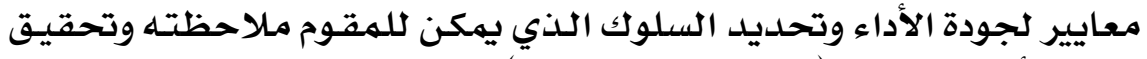

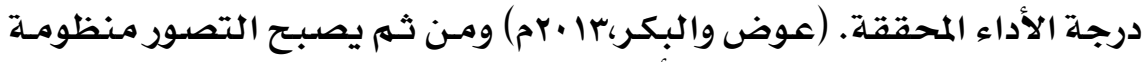

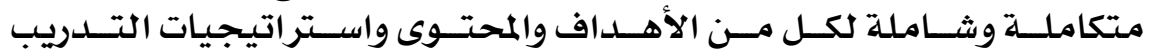

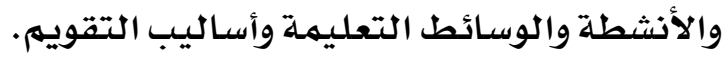

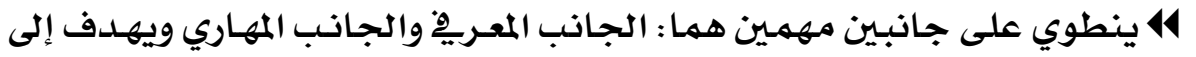

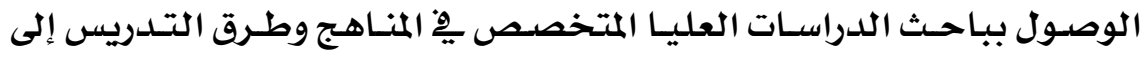

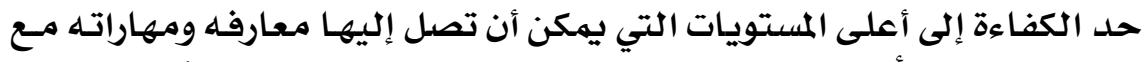

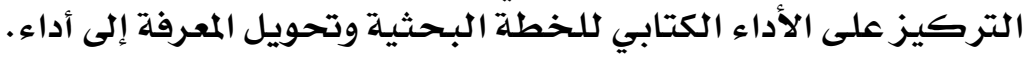

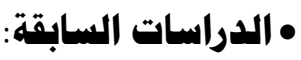

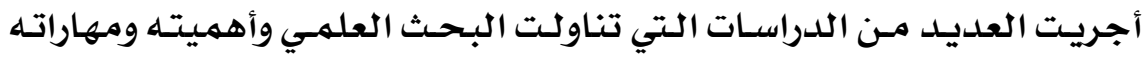

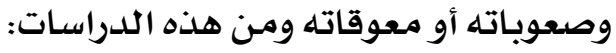

\section{\%}


أجرى كسناوي دراسـة (1991 م) هدفت إلى إبراز سبـل النهوض بـالبـحث العلهي

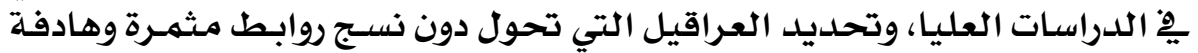

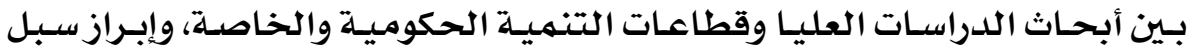

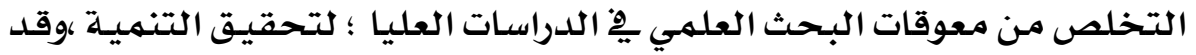
أسفرت الدراسـة عن جملـة من النتائحج كان من أهمهـا : وجود عدة معوقات تحـول

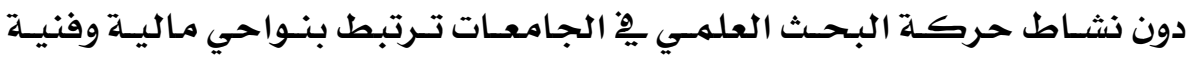

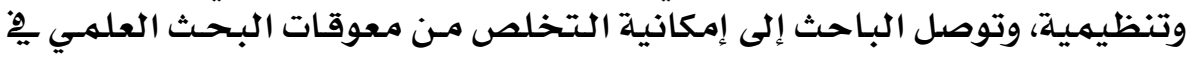

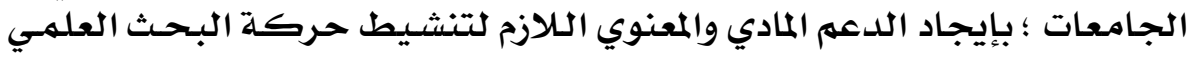
وتلدعيمـه.

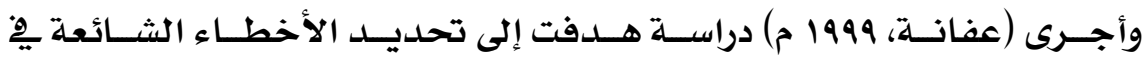

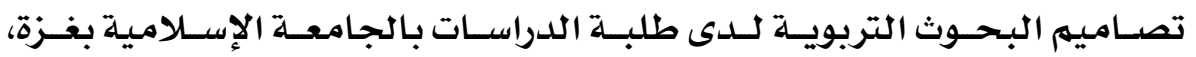

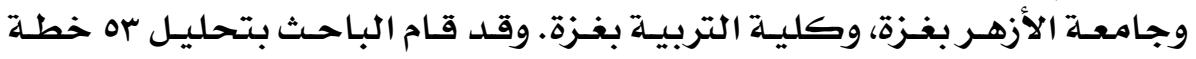

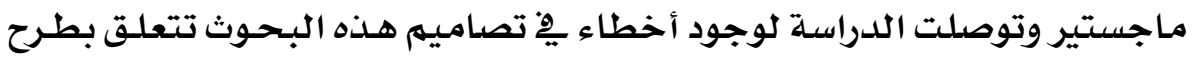

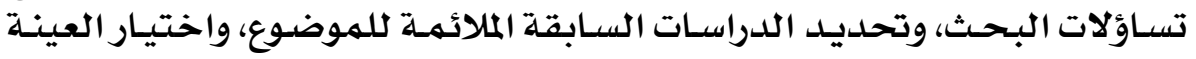

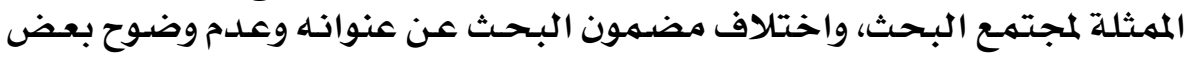

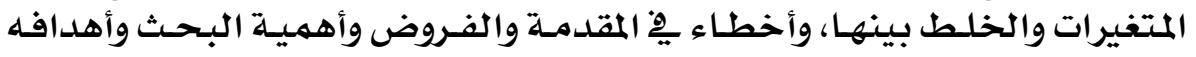

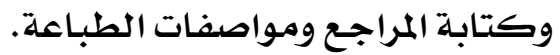

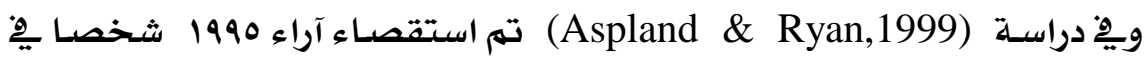

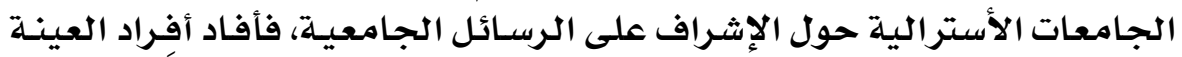

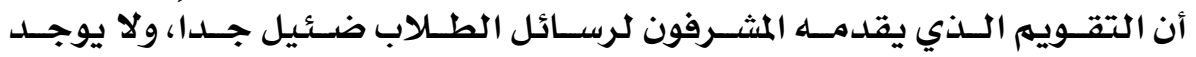

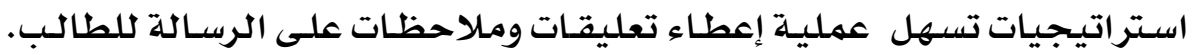

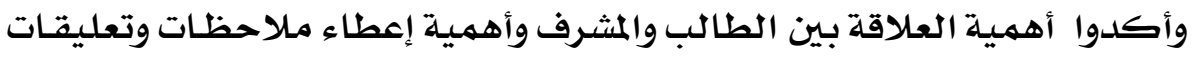
للطالب بصورة منتخظمة بهـا يرتبط بهـراحل إعداد البحث من الخطلة إلى التقرير الشامل.

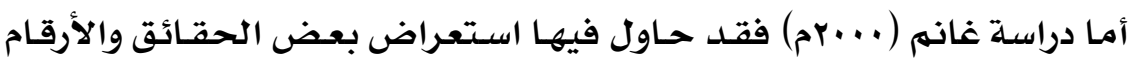

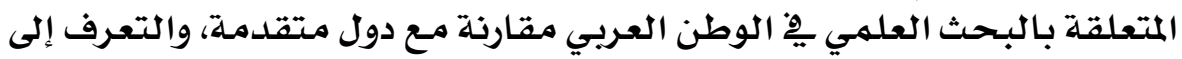

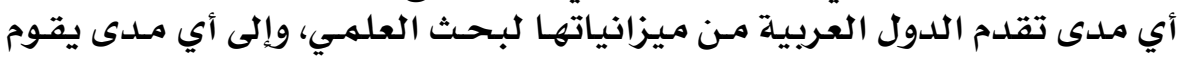

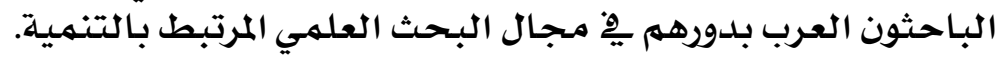

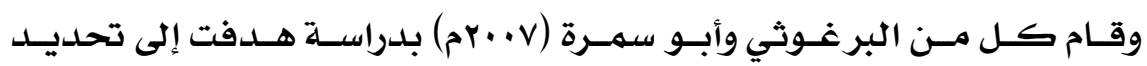

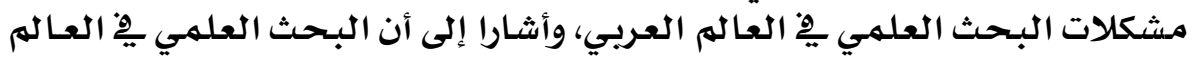

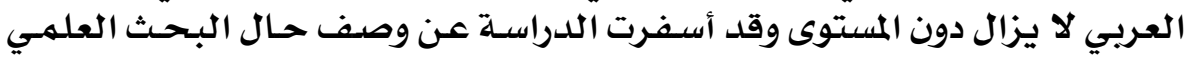

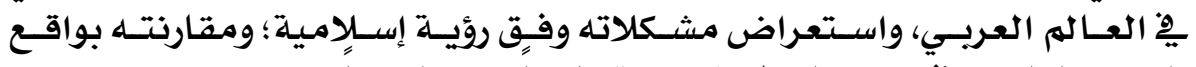

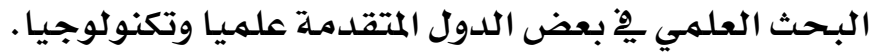

\section{9}




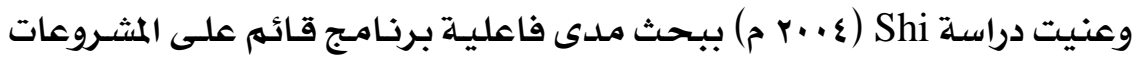

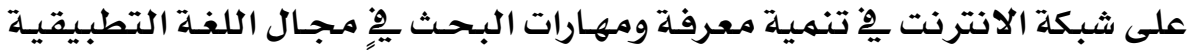

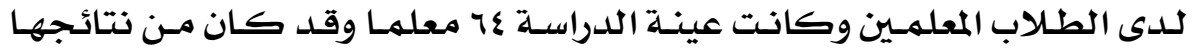

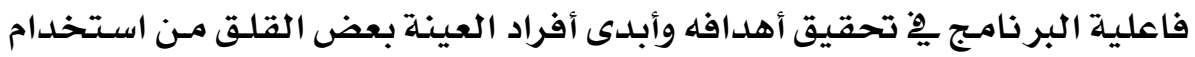

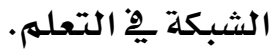

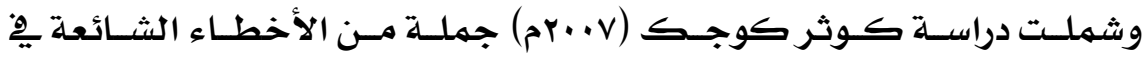

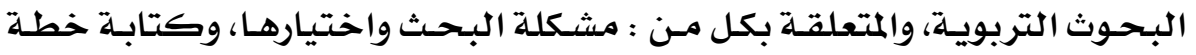

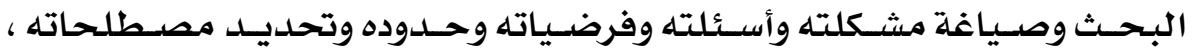

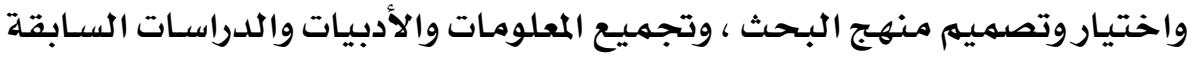

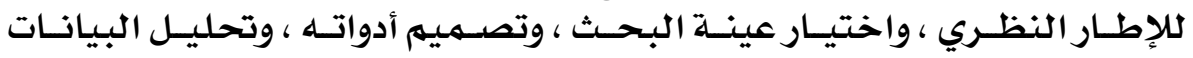

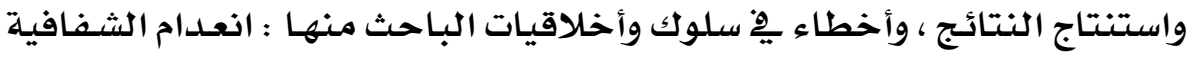

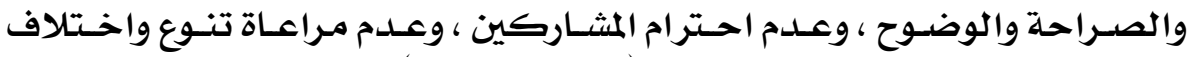

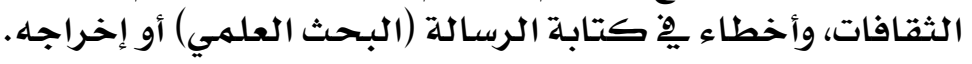

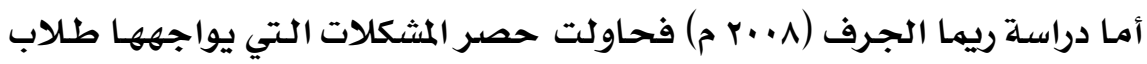

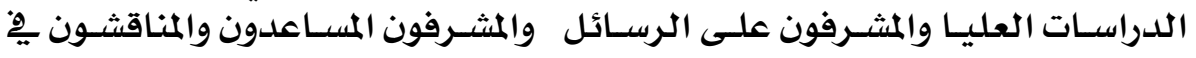

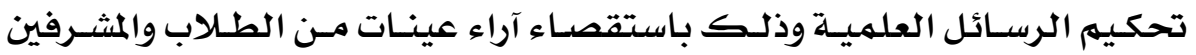

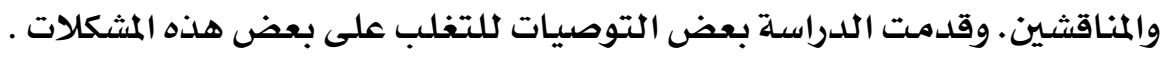

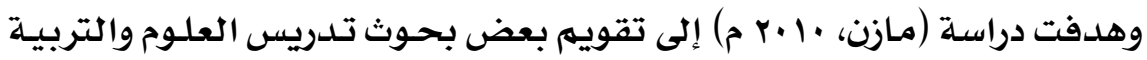

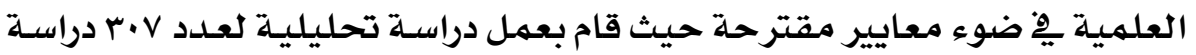

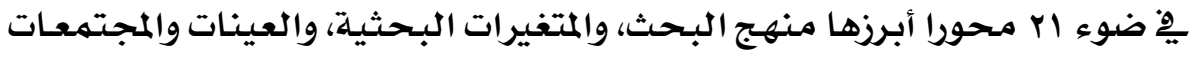

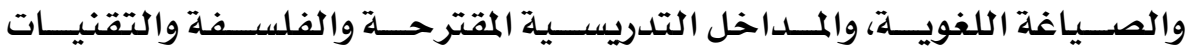

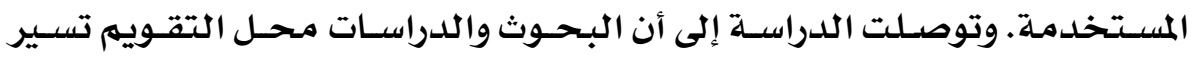

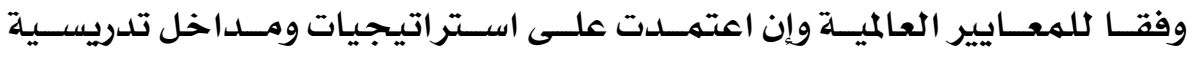

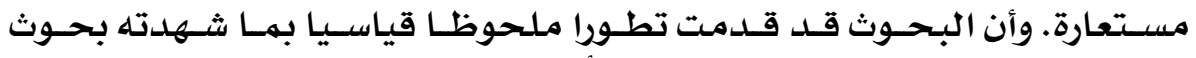

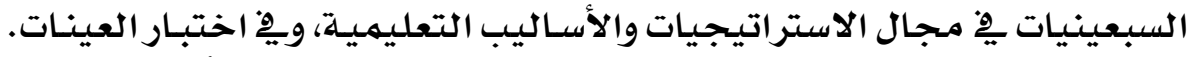

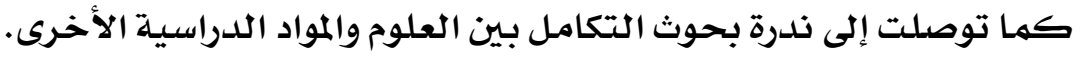

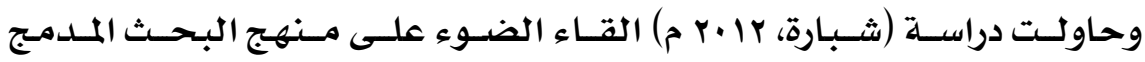

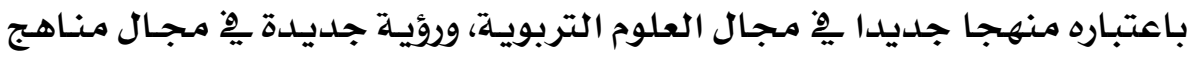

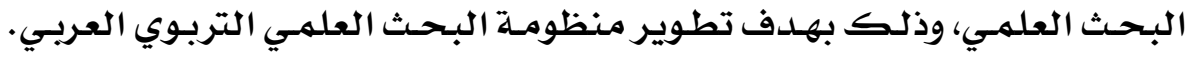

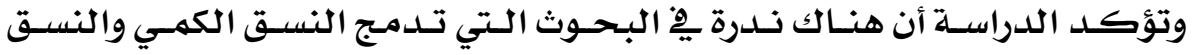

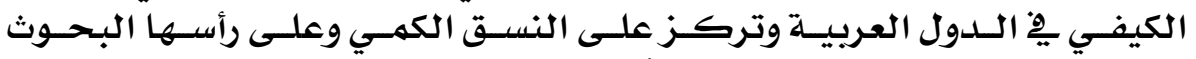

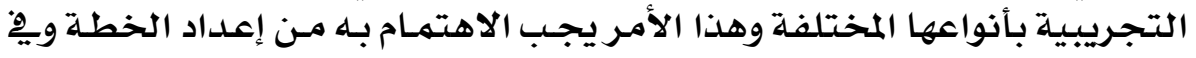
مراحل إعداد البحث المخدية المختلفة وهنة.

\section{rV}




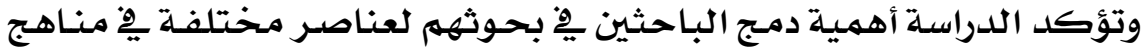

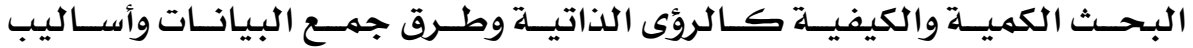

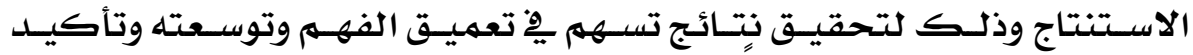

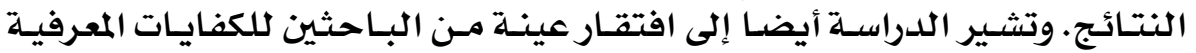

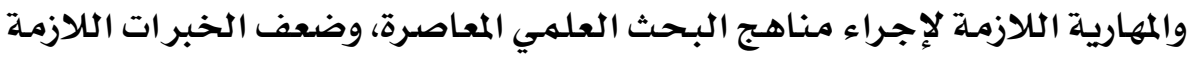

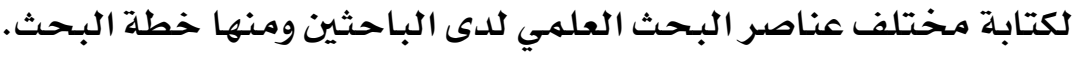

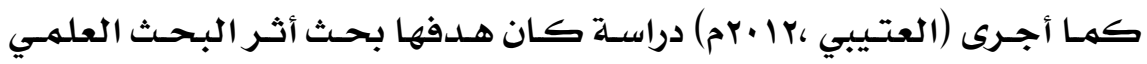

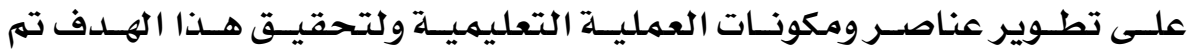

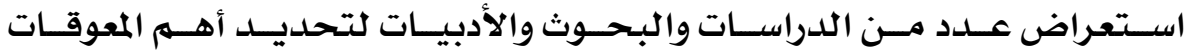

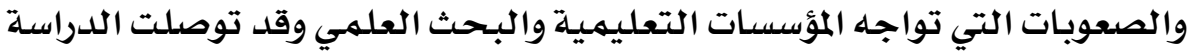

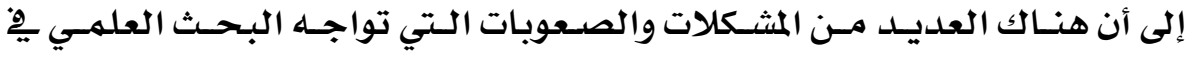

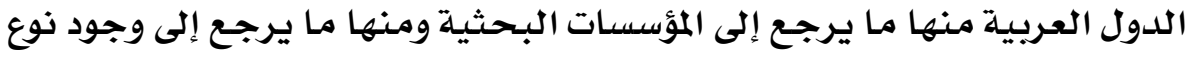

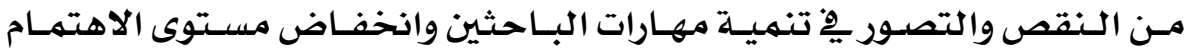

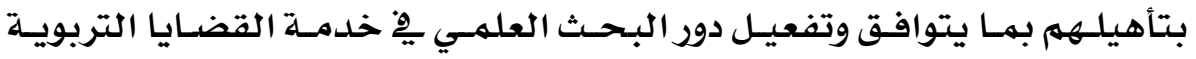

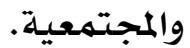

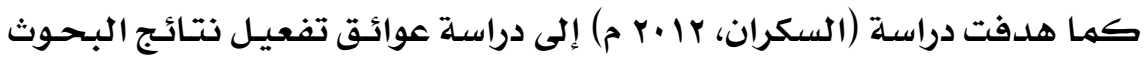

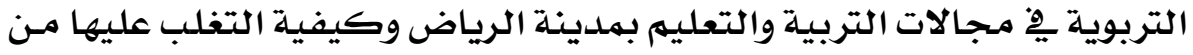

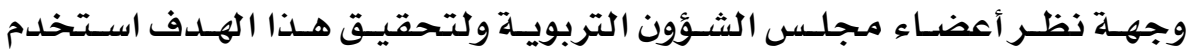

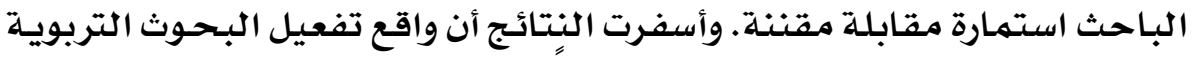

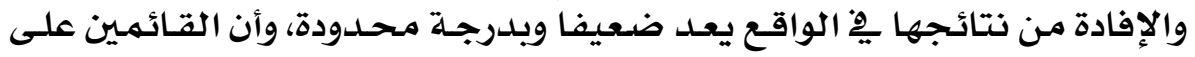

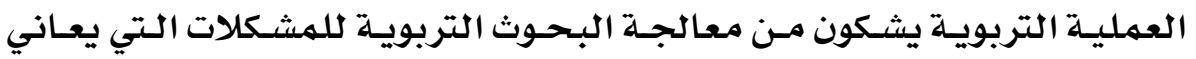

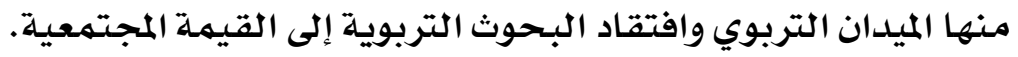

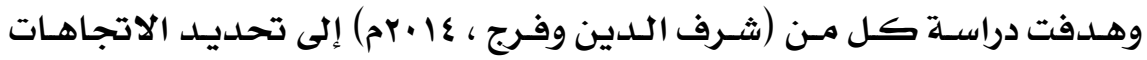

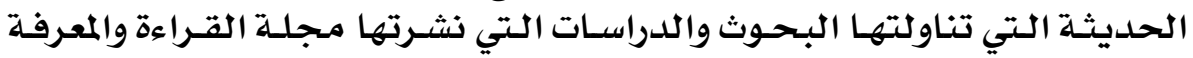

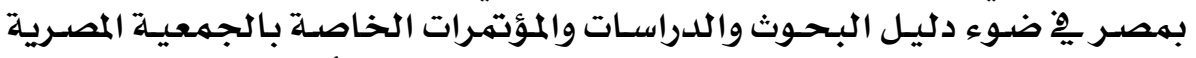

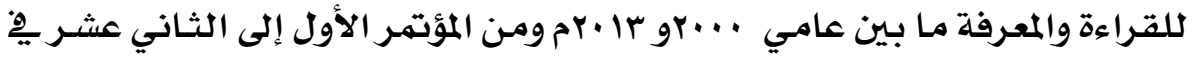

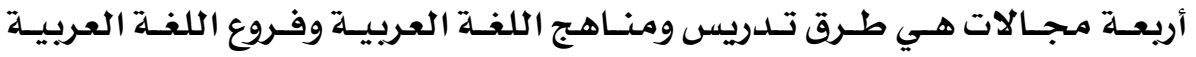

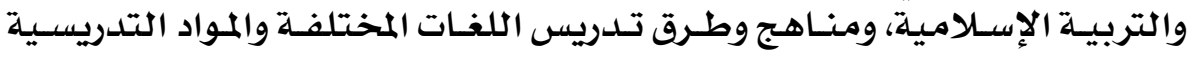

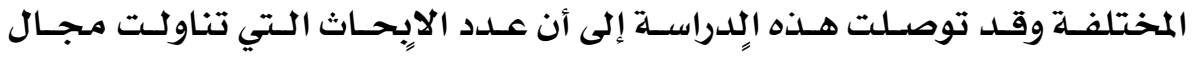

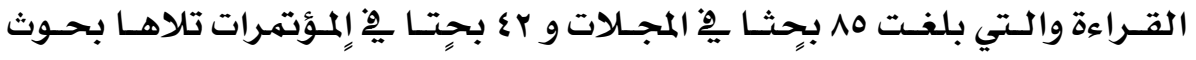

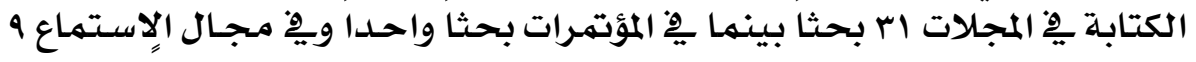

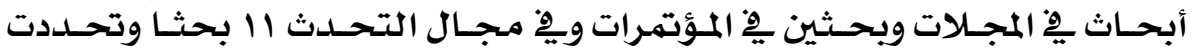

\section{$\boldsymbol{Y} \wedge$}




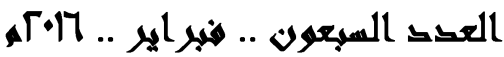

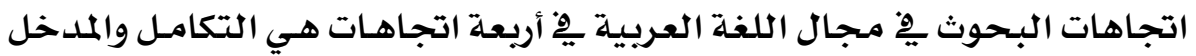
الصوتي والخبرة اللغوية والاتجاه النفسي.

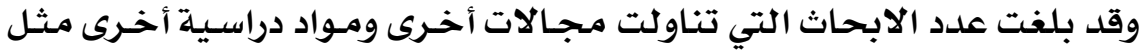

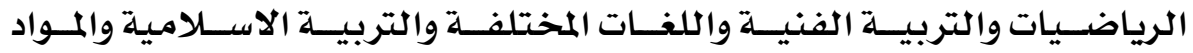

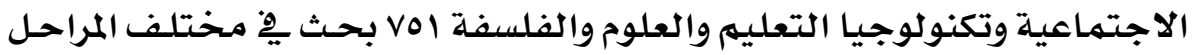

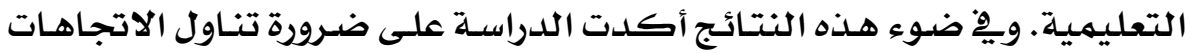

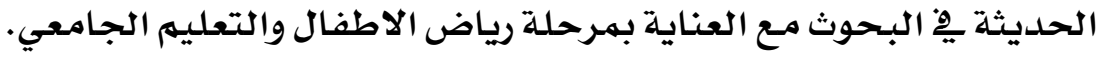

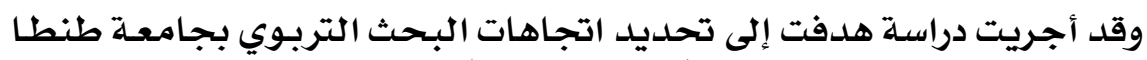

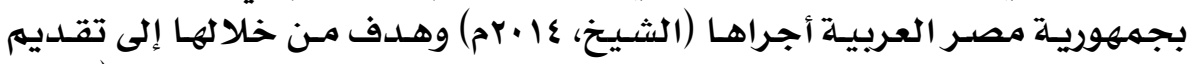

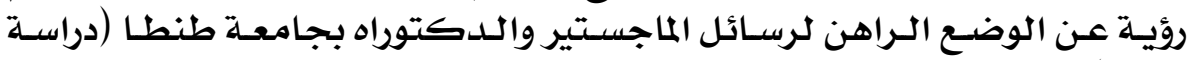

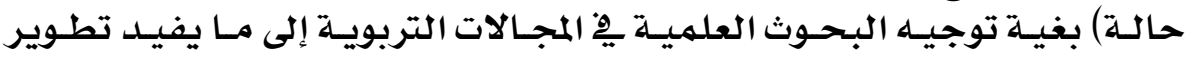

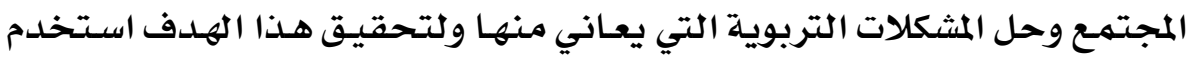

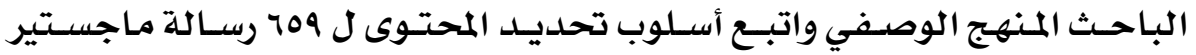

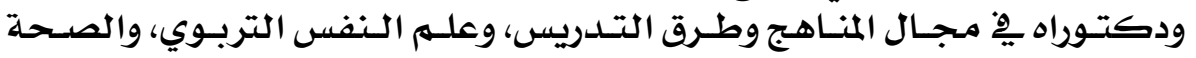

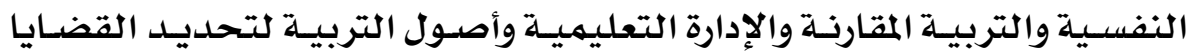

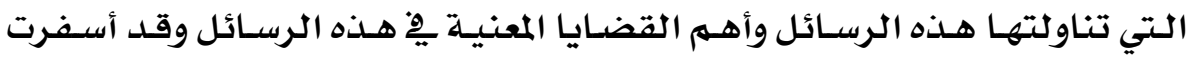

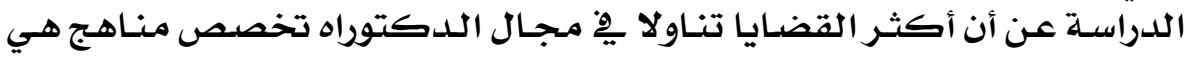

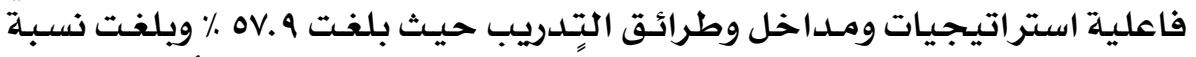

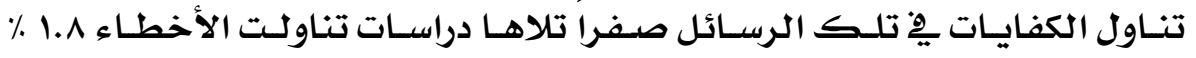

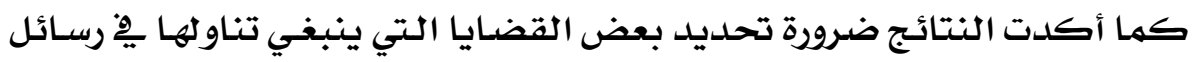
الماجستير والدكتوراه لتناو لها والبحث فيها

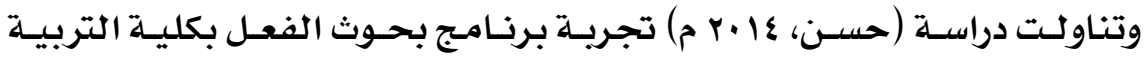

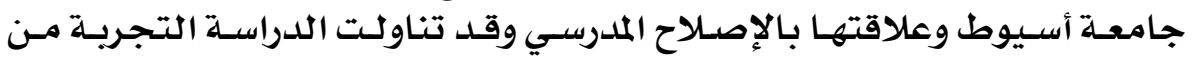

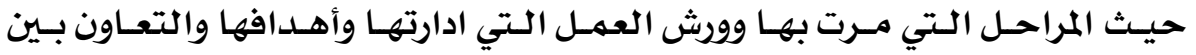

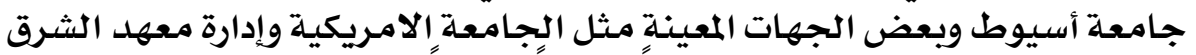

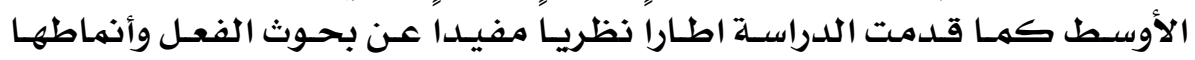

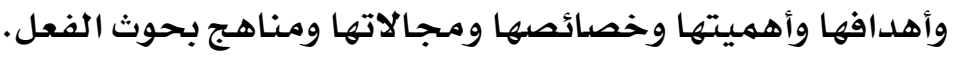

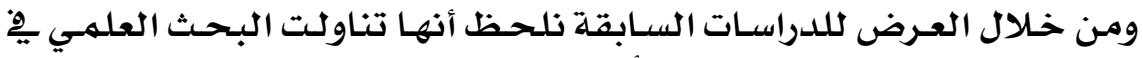

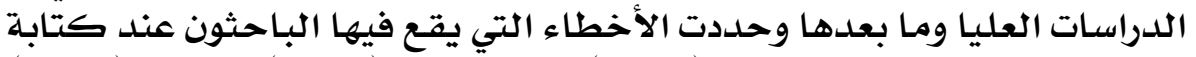

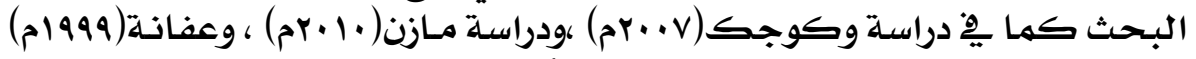

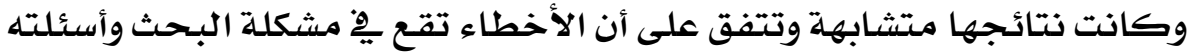

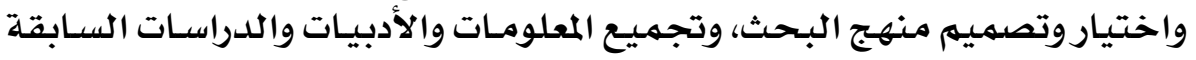

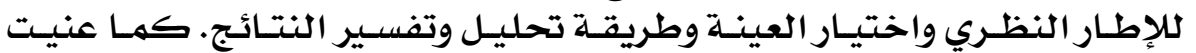

\section{rq}




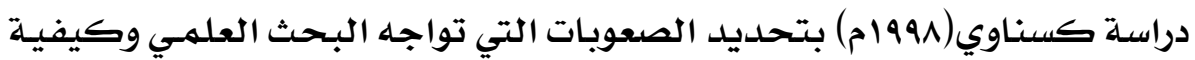

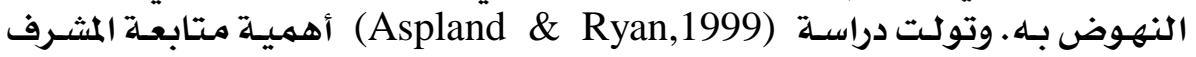

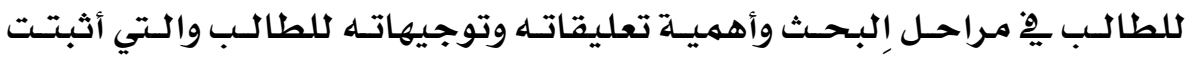

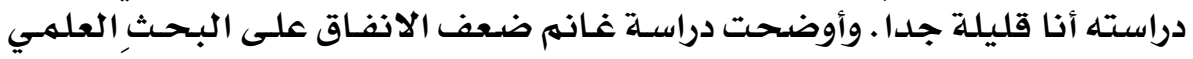

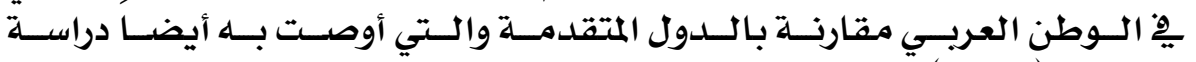
كسناوي(1991م).

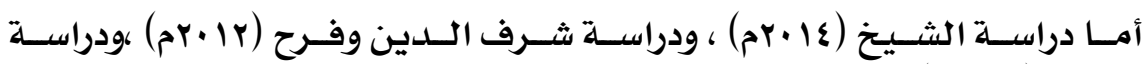

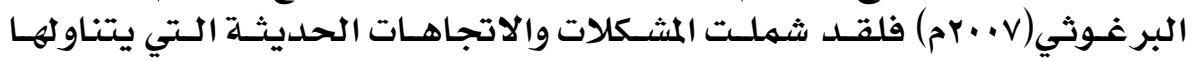

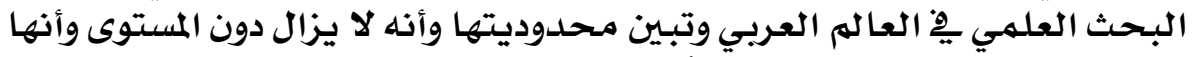

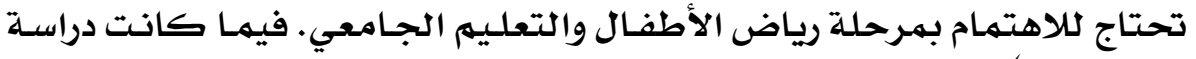

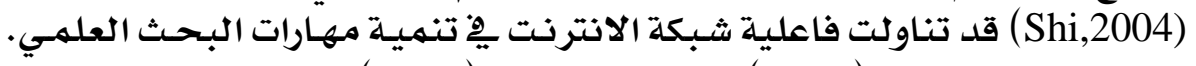

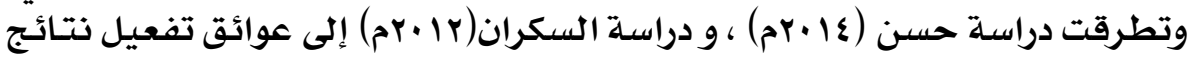
البحوث وعلاقتها بالإصلاح المدرسي.

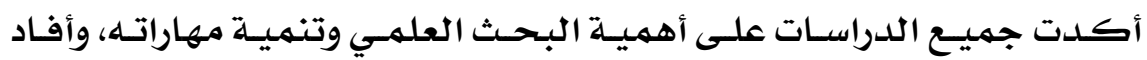

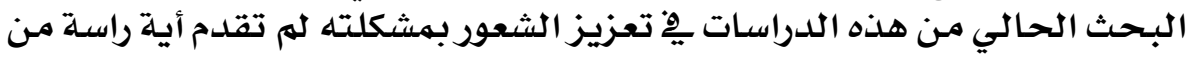

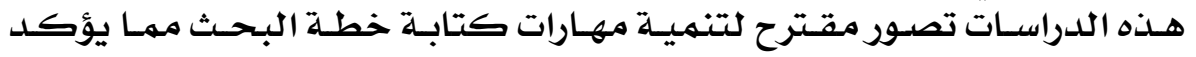

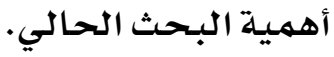

\section{• الإجراءات الميدانية لبحث:}

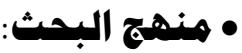

مِّْ ضوء طبيعة البحث الحالي وأهدافه تم استخدام المنهج الوصفي التحليلي

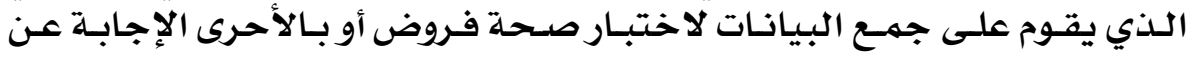

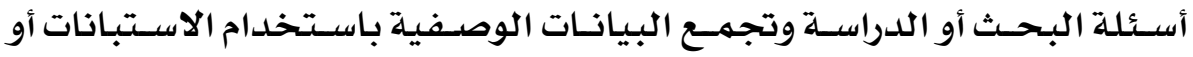

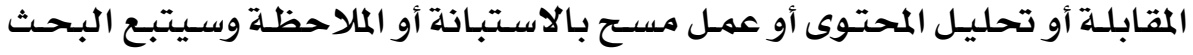

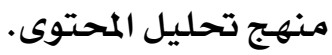

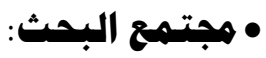

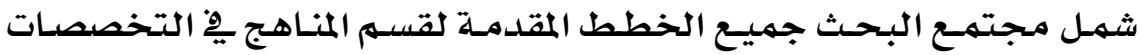

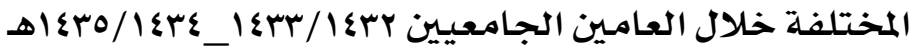

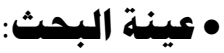

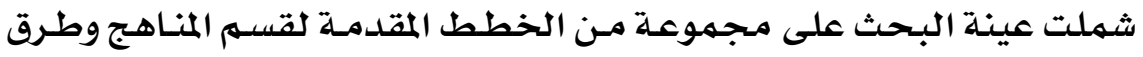

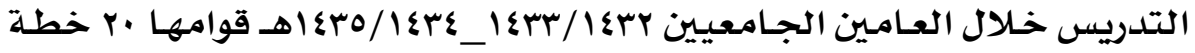
بحثية.

\section{$\varepsilon$.}




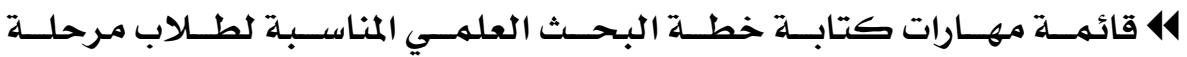

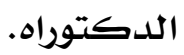

14 بطاقة تحليل محتوى تحوي المهارات البحثيـة لخطة البحث العلهـي لطلاب الدكتوراه تخصص مناهج وطري تهور تدريس.

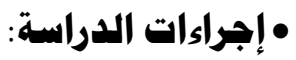
لتحقيق أهداف الدراسة والإجابة عن تساؤلاتها تم استخدام المنهج الوصفي

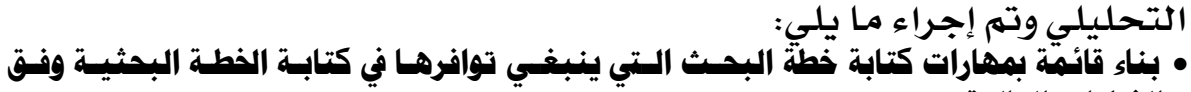
الفطوات التالية: الهدف هن القائمة: هو تحديد مهارات كتابة الخطة البحثية لخطة الدكتوراه تخصص مناهج وطرق تدريس.

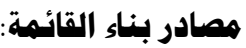
414 الكتب والأدبيات المرتبطة بالبحث العلمي واقعه وتطويره ومهاراته.

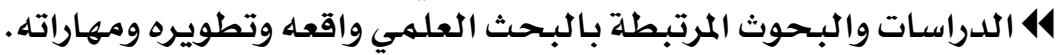
414 دليل الدراسات العليا لكتابة خطة البحأ البحث. 14

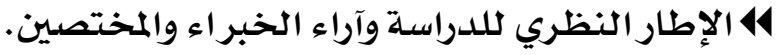
إعداد الصورة الأولية للقائمة: الإطلئ

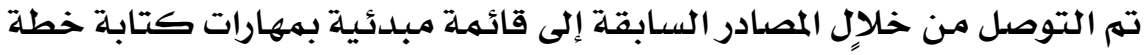

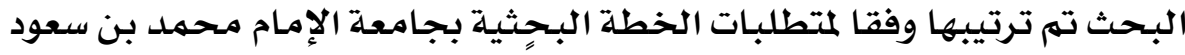

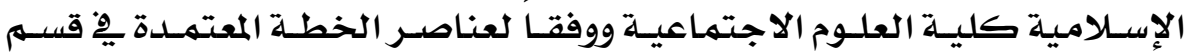

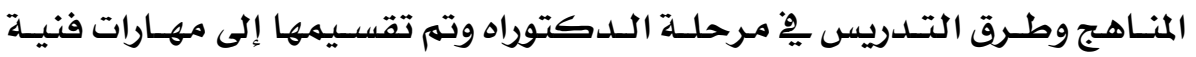

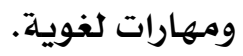

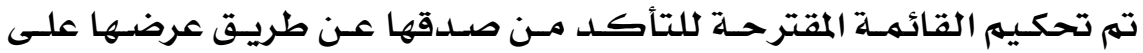

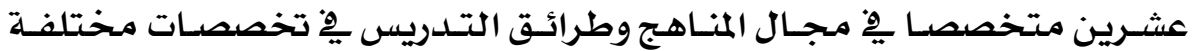

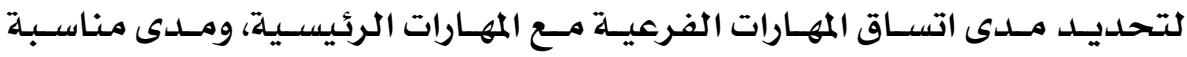

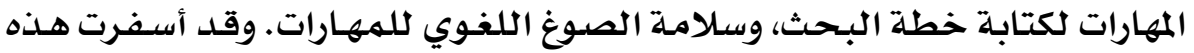

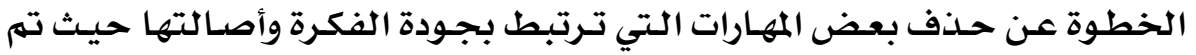

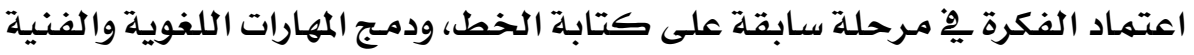

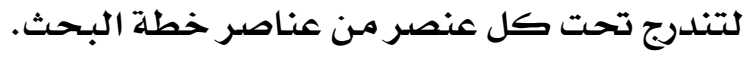

الصورة النهائية للقائمة:

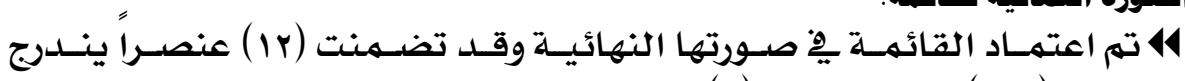

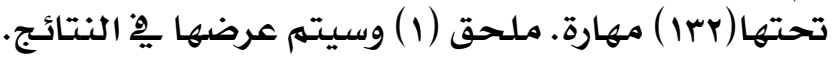

\section{\&}




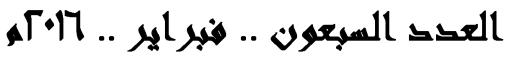

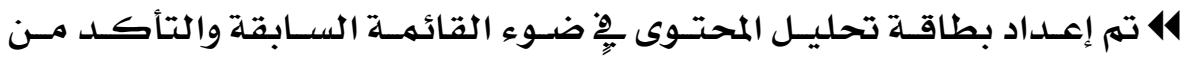

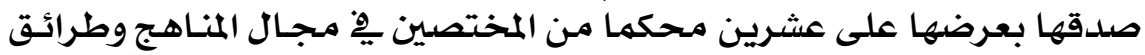

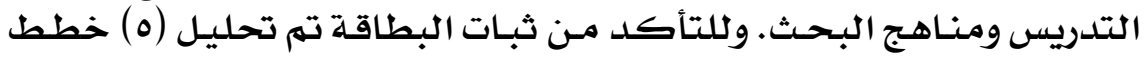

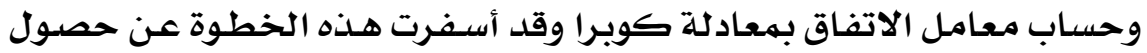

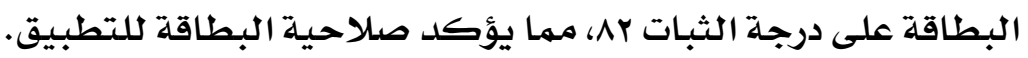

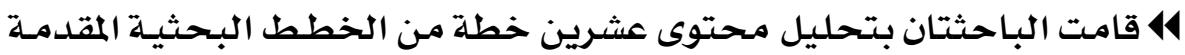

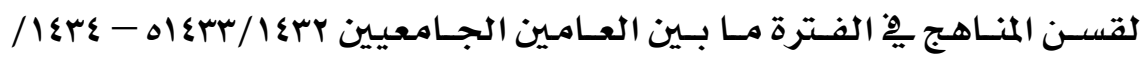

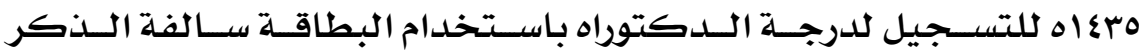

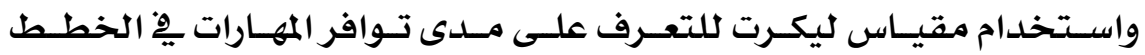

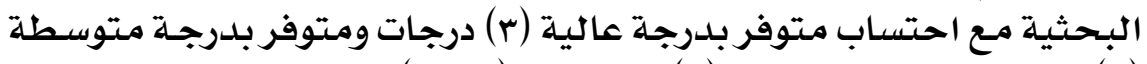

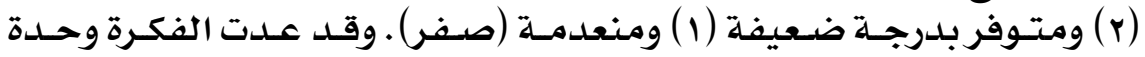
للتحليل

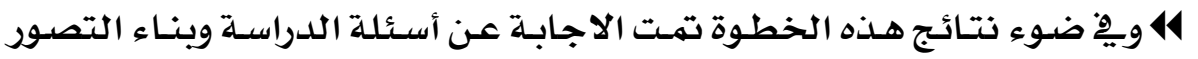

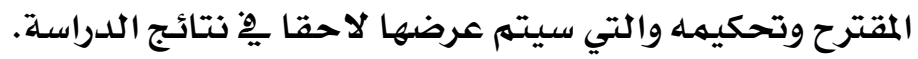

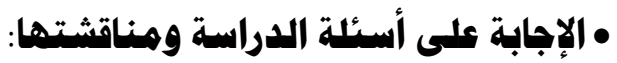

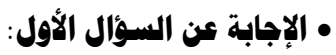

ما مهارات البحث التي ينبغي مراعاتها ِِّو كتابة خطة البحث من قبل طلاب

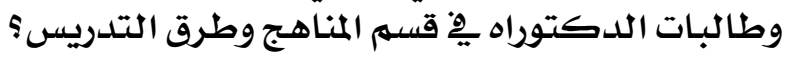

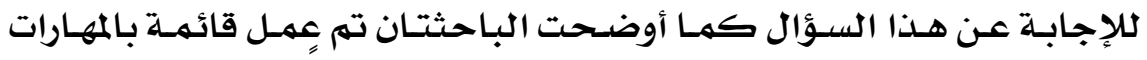

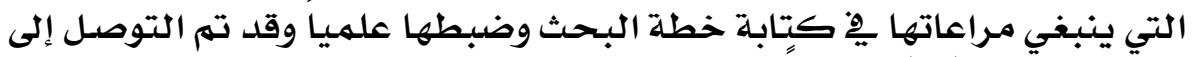

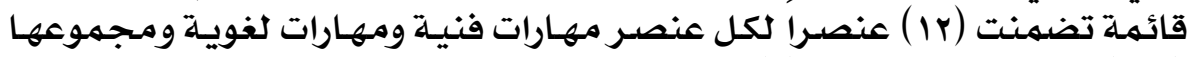

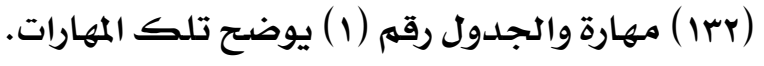

جدول (1) يوضح عناصر مهارات البحث ومهاراتها

\begin{tabular}{|c|c|c|}
\hline عداد المهارات & 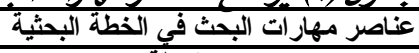 & $p$ \\
\hline 11 & لعنوان الخطّة & \\
\hline $1 \Lambda$ & المقامة والشعور بمشكلة البحث & Y \\
\hline 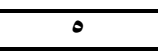 & مشكالة البجتث & $r$ \\
\hline $\mathrm{v}$ & أسئلة البحثض & $\varepsilon$ \\
\hline o & أهداف البحث & 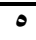 \\
\hline$\Lambda$ & 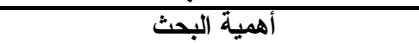 & 7 \\
\hline$\Lambda$ & حلود البحث & $\mathrm{v}$ \\
\hline IT & مصطلحات البحث & $\Lambda$ \\
\hline$\overline{Y T}$ & الإطار النظري & 9 \\
\hline IT & الار اسات السابقة & T. \\
\hline 10 & منهج البحث & $\pi$ \\
\hline I. & التُوتُقيق وأمر اجع & $\overline{T H}$ \\
\hline & & \\
\hline
\end{tabular}

\section{$\varepsilon r$}




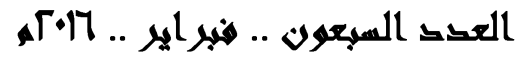

$$
\text { • أولا: عنوان الفانتة المهارات كالتالي: }
$$

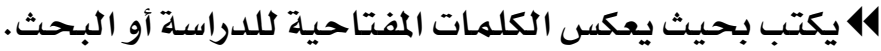

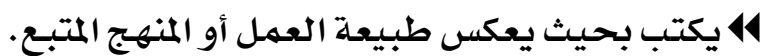

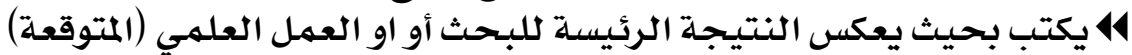

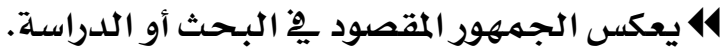
(المارات اللغوية)

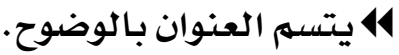

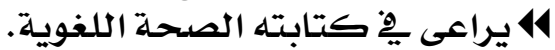
14 يراعى الدقية اللغوية.

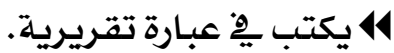

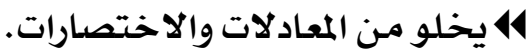

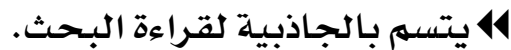

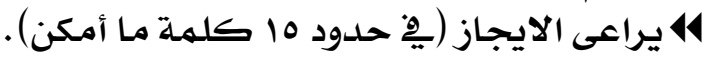

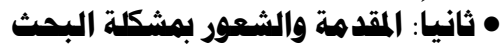
(المهارات الفنية) 14 تمهد المقدمة لمشكلة البحثث.

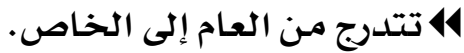
14 11

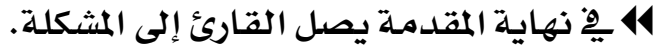

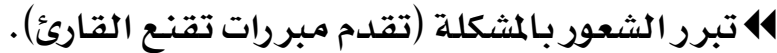

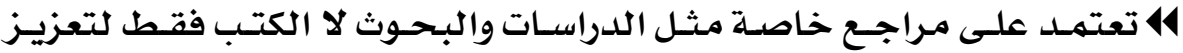
الشعور بالمشكلة.

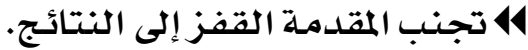

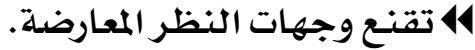

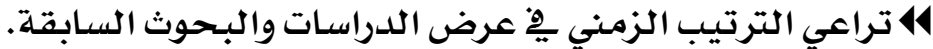

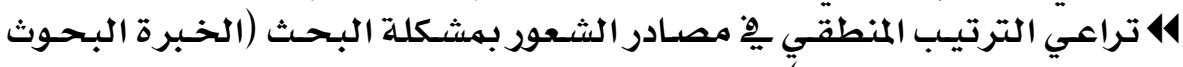

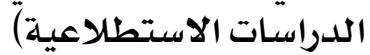

14 تعـرض الدراسـة الاســــاعلاعية بوضـوح الأدوات الإجـراءات، النتـائج وعلاقتهـا (الماتشكلة). (المهارات اللغوية)

14 تكتب بداية المقدمة من تعبير الباحثة.

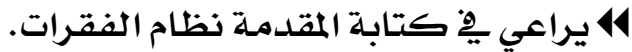
14 تكتب الفقرات بصورة مترابطة.

\section{$\varepsilon r$}




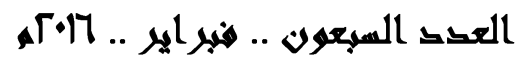

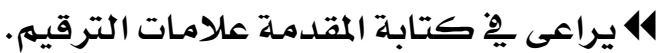

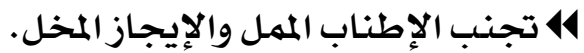

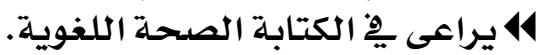

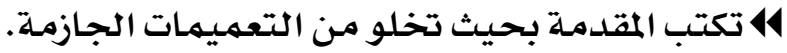

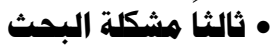

(المهارات الفنية مثلة)

41 تعبر المشكلة عن قصور أو ضعف أو غموض أو أو قضية مثيرة للتفكير.

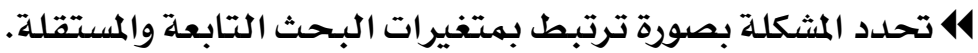

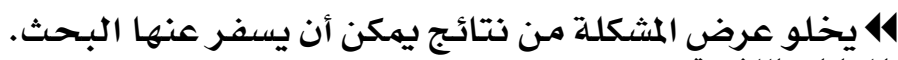
(المهارات اللغوية)

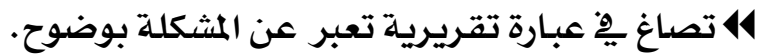

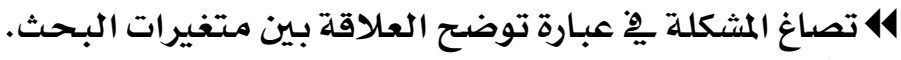

• رابعاً أسئلة البحث البهثة (المهارات الفنية)

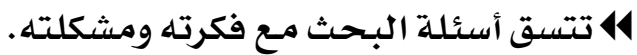

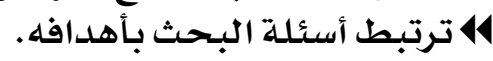

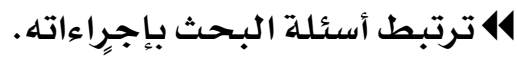

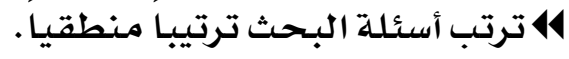

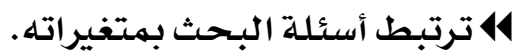
(المهارات اللغوية)

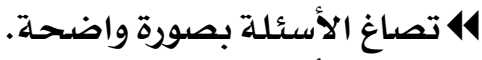
14 تصاغ الأسئلة بصورة دوقئة بصورة افيقة تخلو من التركيب.

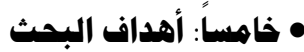
(المهارات الفنيةتِ

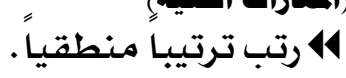

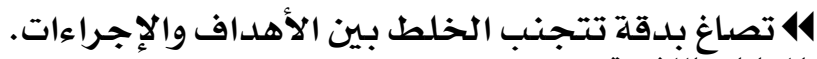

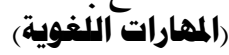
4 4 تخلو من الترات التوكيب والغموض.

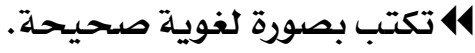

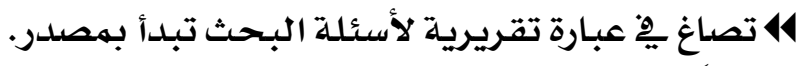

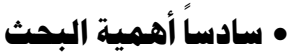
(المهارات الفنية)

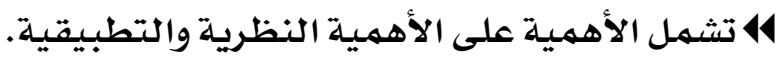
414 تتميز الأهمية الأهمية علظي الأهمية عن الأهمية النظية والتبيقية. 14 ترتبط الأهمية النظرية بالجانب النظري النظية للبحث.

\section{$\varepsilon \varepsilon$}




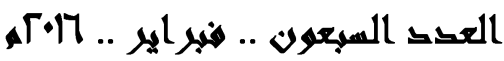

11 ترتبط الأهمية التطبيقية بالجانب التطبيقي للبحث.

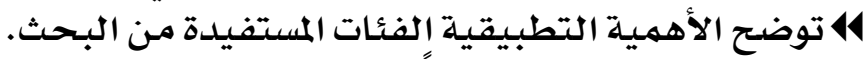

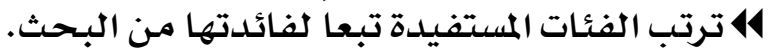
(المهارات اللغوية)

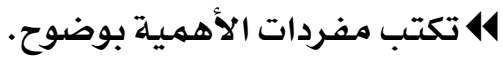
14 تصاغ صياغة لغوية دقيقة.

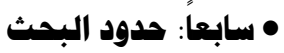
(المهارات الفنية) 14 تشتمل على حدود موضوعية وزمانية ومكانية وبشرية المية.

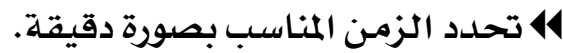
\$ 414

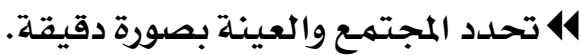

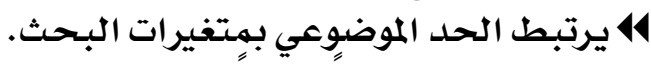

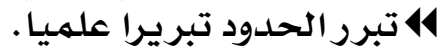
(المهارات اللغوية) 14 تصاغ صياغة لغوية دقيقة.

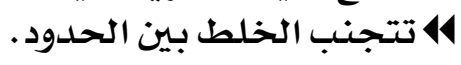

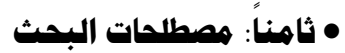
(المهارات الفنية)

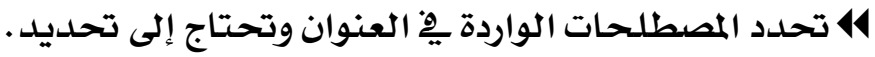
\$ تشمل على التحديد اللغوي للهصطلح.

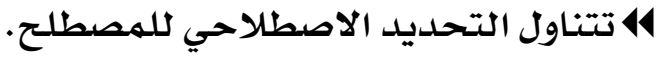
414 تشمل التحديند التحليد الإجرائي للهصطلح. (المهارات اللغوية)

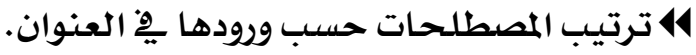

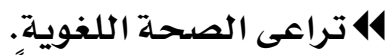
414 يعرف المصطلح الصحريفاً لغوياً مناسباً.

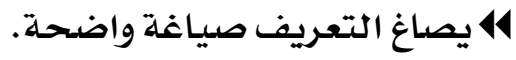

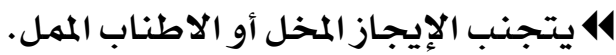

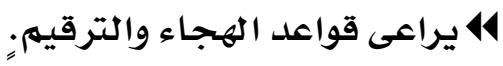
4 414

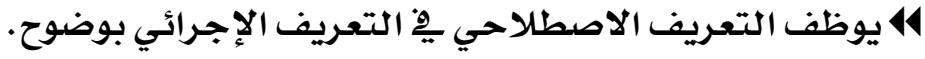

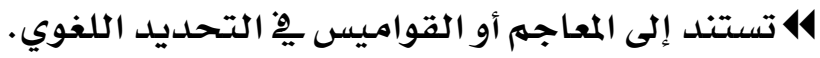

\section{$\varepsilon 0$}


العقد السبعون .. هنبر اير .. 17.مه

• (اسمعا: الإطار النظري

(المهارات الفنية)

14 يكتب الإطار النظري بطريقة تعكس شخصية الباحث.

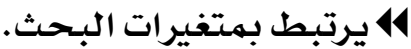

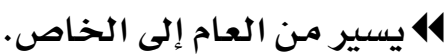

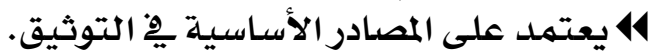

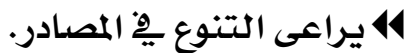

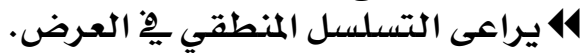
14 يتجنب النقل عن الناقلين.

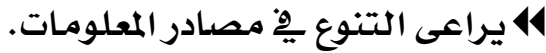
4 يراعى تجنب إيراد أفكار متناقضدة.

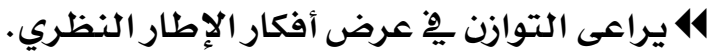

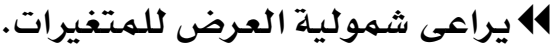
(المهارات اللغوية)

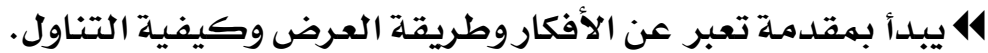

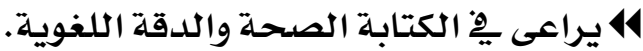

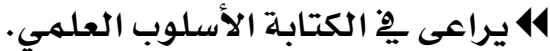

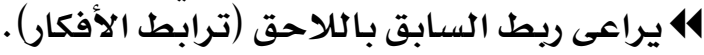

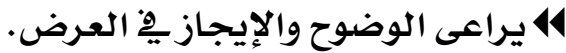

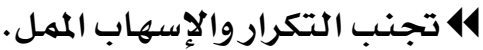

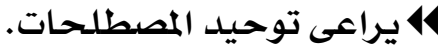

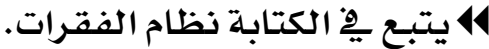

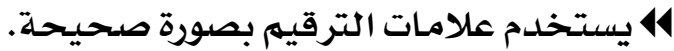

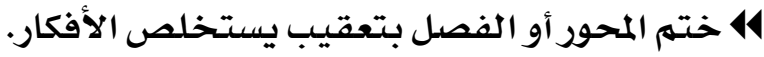

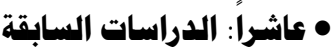
(المهارات الفنية)

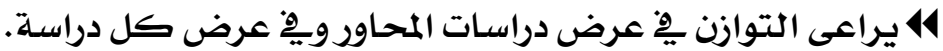
4 ترتبط الدراسات بمتغيرات التوات البحثث.

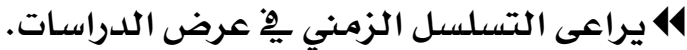

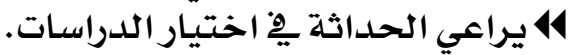

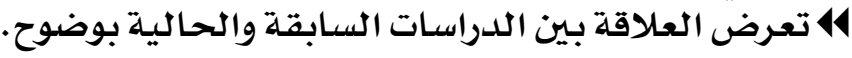

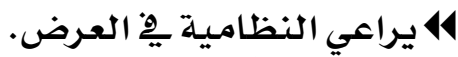
(المهارات آللغوية) 414 يراعي الصحسة اللغوية. 414 يراعي قواعد الهح الكتابة يِّن العناوين الرئيسة والفرعية.

\section{$\varepsilon 7$}




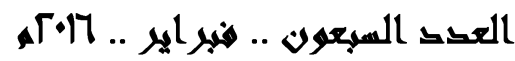

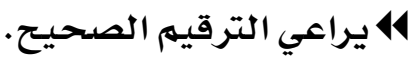

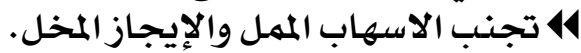

14 يكتب فِ صورة مقالة علمية.

14 يعقب على كل محور مقارو على الفصل الفصل ككل.

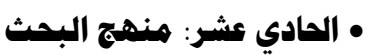
(المهارات الفنية)

4 بكتب المنهج المناسب للبحث.

414

14 يتجنب الخلط بين العينة ومجهموعة البحث.

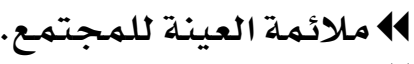

14 يحدد أساليب إحصائية مناسبة.

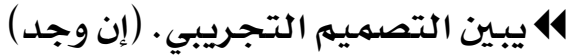

14 يناسب التصميم التجريبي لطبيعة البحئ التحث ومتغيراته (إن وجد) .

14 يحدد أدوات بحث ملائمة.

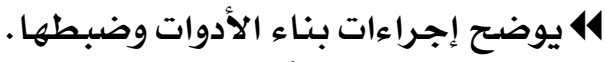

14 يربط الإجراءات بأسئلة البحث. البحر.

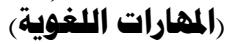

14 يراعي الدقة اللغوية يِّ الكتابة.

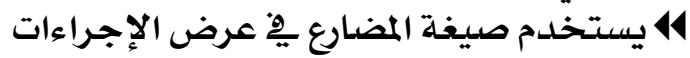

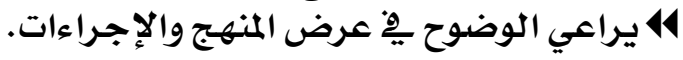

414 يتبع نظام الفقرات يُو الكتابة.

14 يوظف علامات الترقيم بصورة دقيقة.

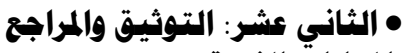

(المهاراتي الفنية)

414 يراعي الاتساق والنظامية يِّ التوثيق.

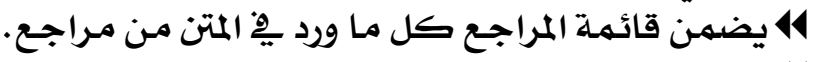

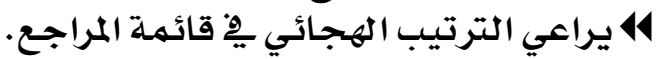

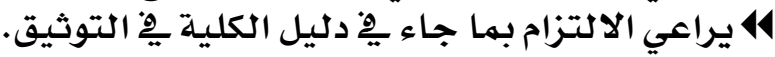

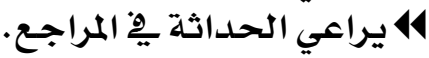
14 يكتب القرآن الكريم بدون رقهم يِّ قائمة المصادر.

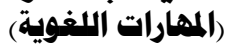

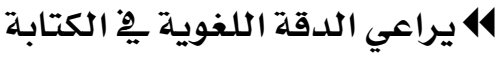

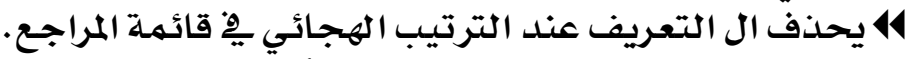
414 يراعي النظامية يُّن كتابة المراجع والأسماء. 44 يوظف علامات الترقيه بصورة دقيقة.

\section{$\varepsilon \vee$}




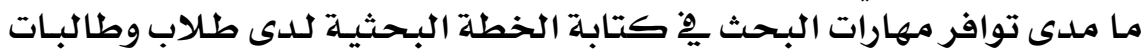

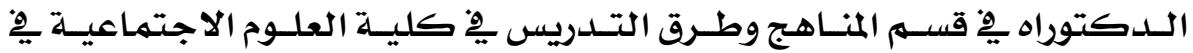

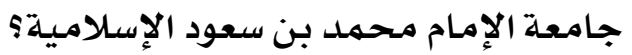

ولإجابة عن هذا السؤال قامت الباحثتان بتحليل عدد مـن الخطط المقدمـة

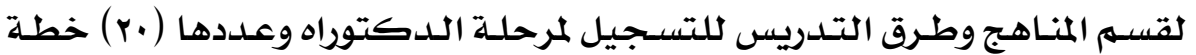

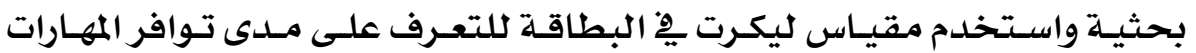

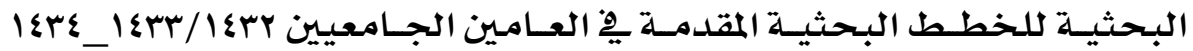

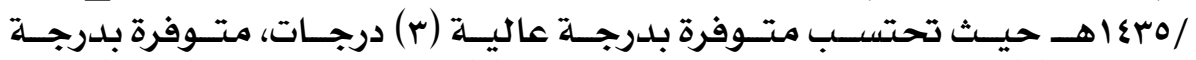

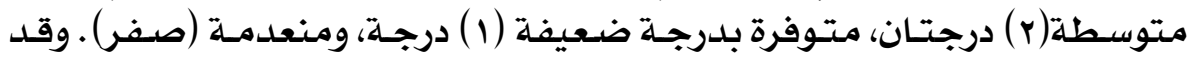

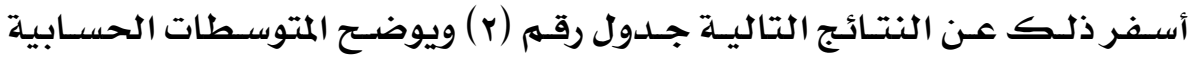
لتوافر تلك المهارات.

جلدول (r) يوضح المتوسطات الحسابية وترتيبها تنازلياً لكل محور في ملدى توافرمهارات البحث في كتابة الخطة البحثية

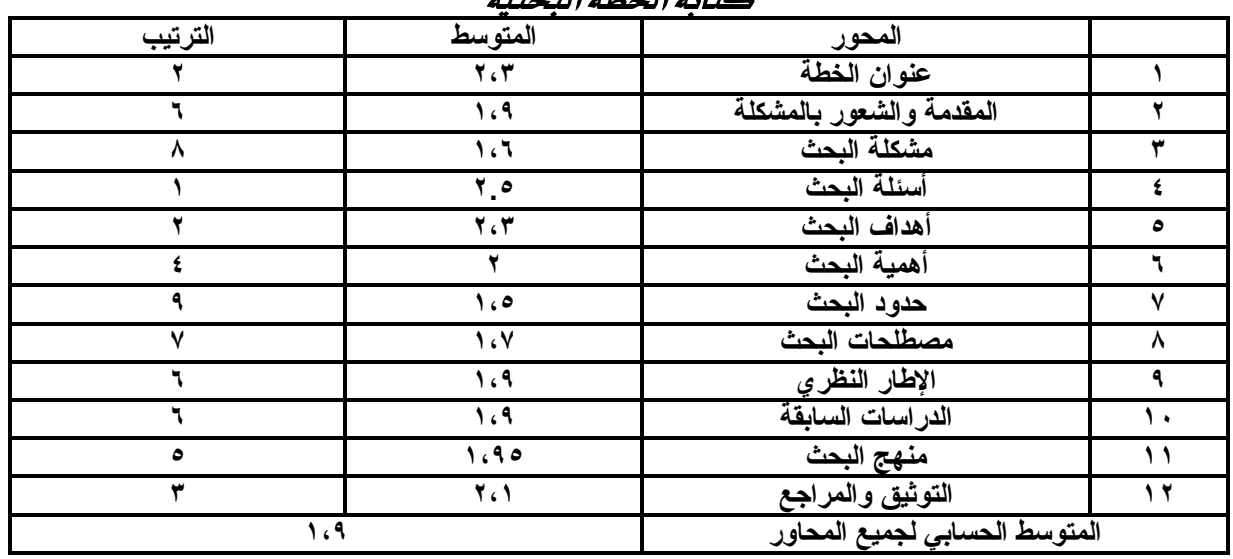

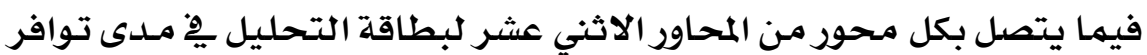

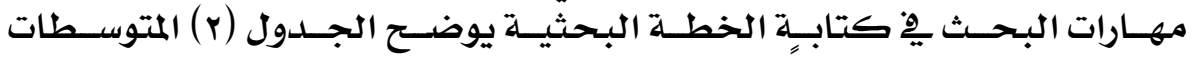

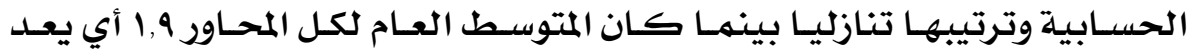

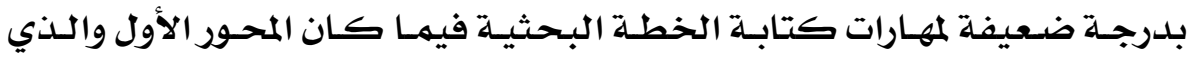

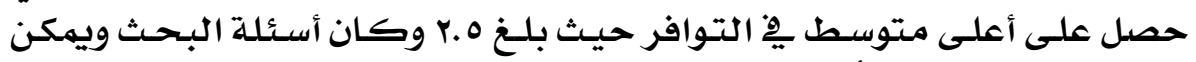

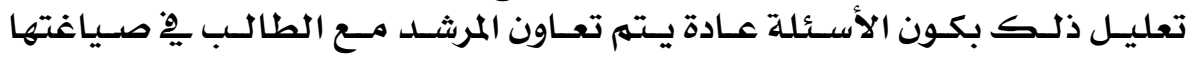

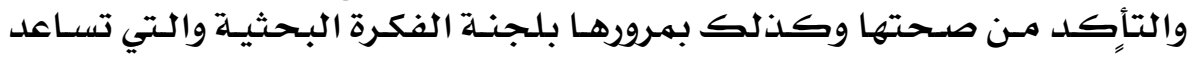

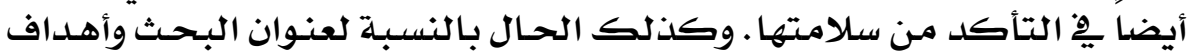

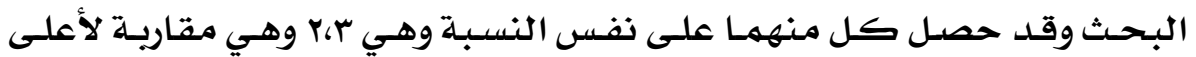

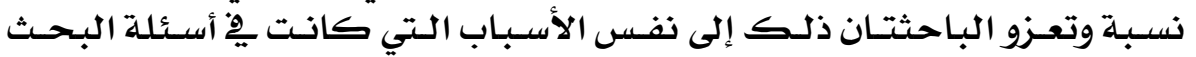

\section{$\varepsilon \wedge$}




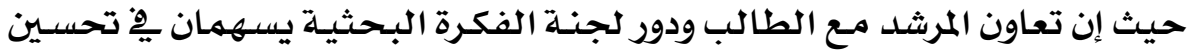

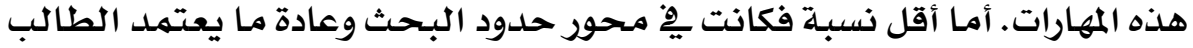

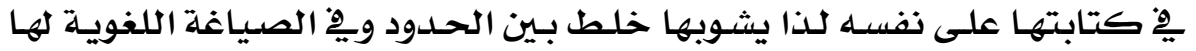
كما تفتقر إلى التبرير العلهي فئسي لكل حلد.

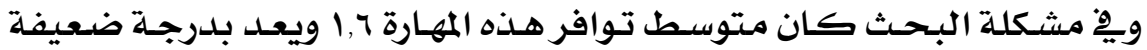

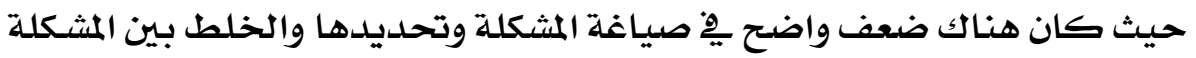

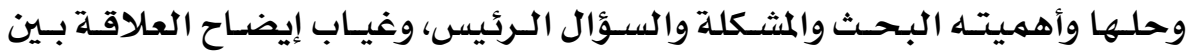

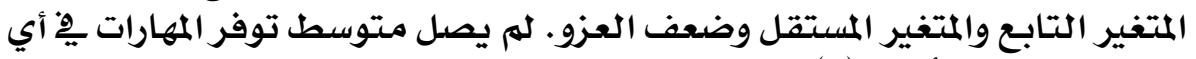
عنصر للدرجـة الأعلى (r).

جلول رقهم (r) يوضح نتائح تحليل الخطط البحثية لكل مهاوة من مهارات البحث

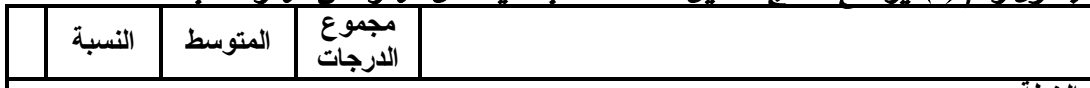

\begin{tabular}{|c|c|c|c|}
\hline & & & (أولاً: عنوات الفنية) الخطة \\
\hline $78 \%$ & 2.4 & 47 & يكتب بحيث يعكس الكلمات المفتاحية للار اسة أو البحث. \\
\hline $90 \%$ & 2.7 & 54 & يكتب بحيث بعكس طبيعة العمل أو المنهج المتبح. \\
\hline $87 \%$ & 2.6 & 52 & يكتب بحيثُ يعكس النتيجةُ الرئيسةُ للبحثَ أو او العمل العلمي (المتوقعة). \\
\hline $85 \%$ & 2.6 & 51 & يعكس الجمهور المقصود في البحث أو الدراسة. \\
\hline & & & 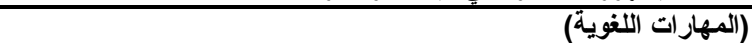 \\
\hline $77 \%$ & 2.4 & 48 & 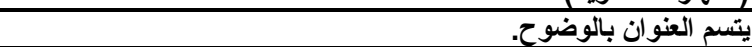 \\
\hline $80 \%$ & 2.3 & 46 & ير يراعى في كتابته الصحة اللنويةًة. \\
\hline $77 \%$ & 2.7 & 53 & 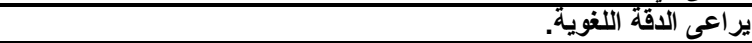 \\
\hline $88 \%$ & 2.6 & 52 & يكتب في عبارة تقريرية. \\
\hline $87 \%$ & 2.0 & 39 & يخلو من المعادلات و الاختصارات. \\
\hline $65 \%$ & 1.8 & 36 & يتسم بالجاذبيةٌ لقراعة البحث. \\
\hline $60 \%$ & 1.8 & 36 & ير يراعى الايجاز (في حدود ه 1 كلمة ما أمكن). \\
\hline & & & 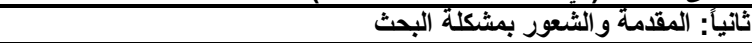 \\
\hline & & & (المهارات الفنية) \\
\hline $77 \%$ & 2.3 & 46 & تمهر المقدمة لمشكلة البحث. \\
\hline $80 \%$ & 2.4 & 48 & تلتارج من العام إلى الخاص. \\
\hline $77 \%$ & 2.3 & 46 & تشرح طبيعة المشكلة. \\
\hline $88 \%$ & 2.7 & 53 & في نهايةً المقدمة يصل القارئ إلى المشكلة. \\
\hline $87 \%$ & 2.6 & 52 & تبرر الثعور بالمشكلة (تقام مبررات تقتع القارئ). \\
\hline $65 \%$ & 2.0 & 39 & 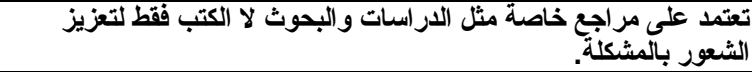 \\
\hline $60 \%$ & 1.8 & 36 & تجنب المقامة القفز إلى النتائج. \\
\hline $65 \%$ & 2.0 & 39 & تقتع وجهات النظر المعارضة. \\
\hline $67 \%$ & 2.0 & 40 & تراعي التّرتبب الزمني في عرض الدراسات و البحوث السابقة. \\
\hline $60 \%$ & 1.8 & 36 & 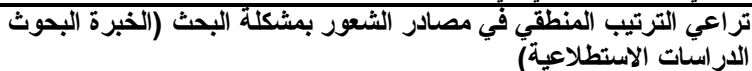 \\
\hline $57 \%$ & 1.7 & 34 & تبالمشكلة). \\
\hline & & & أل ألمهارات اللنوية) \\
\hline
\end{tabular}

\section{$\varepsilon 9$}




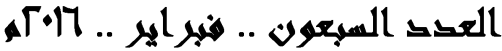

\begin{tabular}{|l|l|l|l|}
\hline & $57 \%$ & 1.7 & 34 \\
\hline & $58 \%$ & 1.8 & 35 \\
\hline & $60 \%$ & 1.8 & 36 \\
\hline & $55 \%$ & 1.7 & 33 \\
\hline & $53 \%$ & 1.6 & 32 \\
\hline & $52 \%$ & 1.6 & 31 \\
\hline & $28 \%$ & 0.9 & 17 \\
\hline
\end{tabular}

تكتب بداية المقدمة من تعبيز الباحثة.

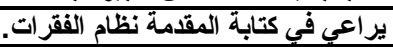

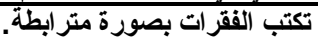

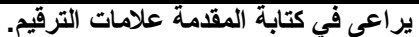

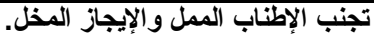

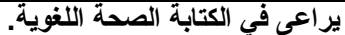
تكتب المقدمة بحيث تخلو مئو من التعميمات الجازمة. ثنأثاً مشكلة البحتة (المهارات (الفنية)

\begin{tabular}{|c|c|c|c|}
\hline $55 \%$ & 1.7 & 33 & تعبر المشكلة عن قصور أو ضعف أو غموض أو قضيةٌ مثيرة للتفكير. \\
\hline $62 \%$ & 1.9 & 37 & تحدد المشكلة بصورة ترتبط بمتغيرات البحث التابعة و المستقلة. \\
\hline $55 \%$ & 1.7 & 33 & يخلو عرض المشكلة من نتائج يمكن أن يسفر عنها البحث. \\
\hline
\end{tabular}

\begin{tabular}{|c|c|c|c|}
\hline $50 \%$ & 1.5 & 30 & تصاغ في عبارة تقريرية تعبر عن المشكلة بوضوح. \\
\hline
\end{tabular}

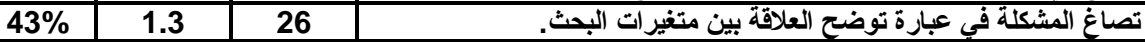
رابعا أسئلة البحث في (المهارات الفنية)

\begin{tabular}{|l|l|l|l|}
\hline & $83 \%$ & 2.5 & 50 \\
\hline & $88 \%$ & 2.7 & 53 \\
\hline & $82 \%$ & 2.5 & 49 \\
\hline & $78 \%$ & 2.4 & 47 \\
\hline & $83 \%$ & 2.5 & 50 \\
\hline \multicolumn{3}{|l|}{} \\
\hline & $78 \%$ & 2.4 & 47 \\
\hline & $80 \%$ & 2.4 & 48 \\
\hline
\end{tabular}

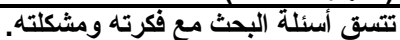

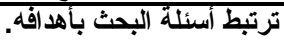

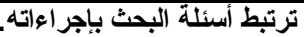

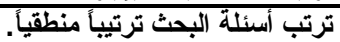

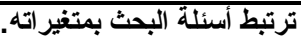
(المهارات اللغوية) تصاغ الأسئلة بصورة و واضحة.

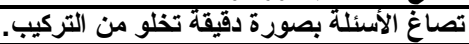
خامساً: أهداف البحثة (المهارات الفنية)

83\%

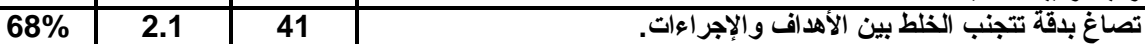

(المهارات اللغوية)
أخلو من التركيب و الغموض. تكتب بصورة لغويةٌ صحيحة. تصاغ في عبارة تقريريةٌة لأسئلة البحثة تبدأ بمصدر. سادسأ أهمية البحث فئر (المهارات الفنية)

\begin{tabular}{|c|c|c|c|}
\hline $75 \%$ & 2.3 & 45 & تشمل الأهمية على الأهمية النظرية و التطبيقية. \\
\hline $70 \%$ & 2.1 & 42 & يميز الأهمية النظرية عن الأهمية التطبيقية. \\
\hline $55 \%$ & 1.7 & 33 & يربط الأهمية النظرية بالجاتب النظري للبحث. \\
\hline $72 \%$ & 2.2 & 43 & يربط الأهمية التطبيقية بالجاتب التطبيقي للبحث. \\
\hline $62 \%$ & 1.9 & 37 & يوضـح الأهمبة التطبيقية الفئات المستفيدة من البحث \\
\hline $53 \%$ & 1.6 & 32 & يرتب الفئات المستفيدة تبعاً لفائدتها من البحث. \\
\hline
\end{tabular}

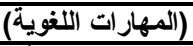

إيكتب مفردات الأهميةٌة بوضوح.

\begin{tabular}{|l|l|l|}
\hline $72 \%$ & 2.2 & 43 \\
\hline
\end{tabular}
تصاغ صياغة لغوية دقيقة سابعاً : حلود البحث لفوبة (المهارات الفنية) 


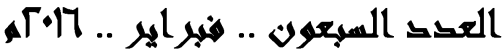

\begin{tabular}{|c|c|c|c|}
\hline $53 \%$ & 1.6 & 32 & يحدد الزمن المناسب بصورة دقيقة. \\
\hline $43 \%$ & 1.3 & 26 & يحدد المكان بصورة دقيقة. \\
\hline $47 \%$ & 1.4 & 28 & يحداد المجتمع والعينة بصورة دقيقة. \\
\hline $45 \%$ & 1.4 & 27 & يربط الحد الموضوعي بمتغيرات البحث. \\
\hline $35 \%$ & 1.1 & 21 & يبرر الحدود تبريرأ علمياً. \\
\hline & & & (المهارات اللغوية) \\
\hline $60 \%$ & 1.8 & 36 & يصوغ صياغة لغوية دقيقة . \\
\hline $58 \%$ & 1.8 & 35 & يتجنب الخلط بين الحدود. \\
\hline & & & ثُامناً: مصطلحات البحث \\
\hline & & & (المهارات (القنية) \\
\hline $70 \%$ & 2.1 & 42 & يحدد المصطلحات الواردة في العنوان وتحتاج إلى تحديد. \\
\hline $25 \%$ & 0.8 & 15 & تثشمل على التحديد اللغوي للمصطلح. \\
\hline $48 \%$ & 1.5 & 29 & تتناول التحليد الاصطلاحي للمصطلح. \\
\hline $68 \%$ & 2.1 & 41 & تشمل التحديد الإجرائي للمصطلح. \\
\hline & & & (المهار ات اللغوية) \\
\hline $75 \%$ & 2.3 & 45 & يرتب المصطلحات حسب ورودها في العنوان. \\
\hline $70 \%$ & 2.1 & 42 & تز اعى الصحة اللغوية. \\
\hline $28 \%$ & 0.9 & 17 & يعرف المصطلح تعريفاً لغوياً مناسباً. \\
\hline $67 \%$ & 2.0 & 40 & يصوغ التعريف صياغة واضحة. \\
\hline $67 \%$ & 2.0 & 40 & يتجنب الإيجاز المخل أو الاطناب الممل. \\
\hline $63 \%$ & 1.9 & 38 & يز اعى قو اعد الهجاء والترقيم. \\
\hline $73 \%$ & 2.2 & 44 & ير اعى أن يكون التعريف جامعاً مانعاً. \\
\hline $60 \%$ & 1.9 & 36 & يوظف التعريف الاصطلاحي في التعريف الإجر ائي بوضوح. \\
\hline $37 \%$ & 1.1 & 22 & يتستند إلى المعاجم أو القواميس في التحديد اللغوي. \\
\hline & & & تاسعاً الإطار النظري \\
\hline & & & (المهارات الفنية) \\
\hline $48 \%$ & 1.5 & 29 & يكتب الإطار النظري بطريقة تعكس شخصية الباحث. \\
\hline $63 \%$ & 1.9 & 38 & يرتبط بمتغيرات البحث. \\
\hline $68 \%$ & 2.1 & 41 & يسبير من العام إلى الخاص. \\
\hline $65 \%$ & 2.0 & 39 & يعتمد على المصادر الأساسية في التوثيق. \\
\hline $72 \%$ & 2.2 & 43 & ير اعى التنوع في المصادر. \\
\hline $68 \%$ & 2.1 & 41 & ير اعى التسلسل المنطقي في العرض. \\
\hline $63 \%$ & 1.9 & 38 & يتجنب النقل عن الناقلين. \\
\hline $63 \%$ & 1.9 & 38 & ير اعى التنوع في مصادر المعلومات. \\
\hline $58 \%$ & 1.8 & 35 & ير اعى تجنب إير اد أفكار متناقضة. \\
\hline $70 \%$ & 2.1 & 42 & يراعى التوازن في عرض أفكار الإطار النظري. \\
\hline $68 \%$ & 2.1 & 41 & ير اعى شمولية العرض للمتغير ات. \\
\hline & & & (المهارات اللغوية) \\
\hline $47 \%$ & 1.4 & 28 & يبدأ بمقدمة تعبر عن الأفكار وطريقة العرض وكيفية التناول. \\
\hline $68 \%$ & 2.1 & 41 & يراعى في الكتابة الصحة والدقة اللغوية. \\
\hline $65 \%$ & 2.0 & 39 & ير اعى في الكتابة الأسلوب العلمي. \\
\hline $60 \%$ & 1.8 & 36 & ير اعى ربط السابق باللاحق (ترابط الأفكار). \\
\hline $70 \%$ & 2.1 & 42 & ير اعى الوضوح و الإيجاز في العرض. \\
\hline $62 \%$ & 1.9 & 37 & يتجنب التكرار و الإسهاب الممل. \\
\hline $65 \%$ & 2.0 & 39 & ير اعى توحيا المصطلحات. \\
\hline $65 \%$ & 2.1 & 39 & يتبع في الكتابة نظام الفقرات. \\
\hline $63 \%$ & 1.9 & 38 & يستخلم علامات الترقيم بصورة صحيحة. \\
\hline
\end{tabular}

\section{1}




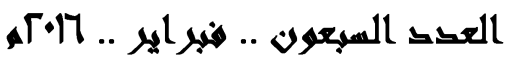

\begin{tabular}{|c|c|c|c|}
\hline $40 \%$ & 1.2 & 24 & يختم المحور أو الفصل بتعقيب يستخلص الأفكار. \\
\hline & & & عاشر أ: الار اسات السابقة \\
\hline & & & (المهارات الفنية) \\
\hline $60 \%$ & 1.8 & 36 & يراعى التوازن في عرض دراسات المحاور وفي عرض كل دراسة. \\
\hline $70 \%$ & 2.1 & 42 & ترتبط الدراسات بمتغيرات البحث. \\
\hline $73 \%$ & 2.2 & 44 & ير اعى التسلسل الزمني في عرض الاراسات. \\
\hline $73 \%$ & 2.2 & 44 & يراعي الحداثة في اختيار الاراسات. \\
\hline $63 \%$ & 1.9 & 38 & يعرض العلاقةٌ بينَ الار اسات السابقة و الحاليّة بوضوح. \\
\hline $57 \%$ & 1.7 & 34 & ير اعي النظامية في العرض. \\
\hline & & & (المهارات اللغوية) \\
\hline $60 \%$ & 1.8 & 36 & ير اعي الصحة اللغوية. \\
\hline $70 \%$ & 2.1 & 42 & ير اعي قو اعد الكتابة في العناوين الرئيسة و الفرعية. \\
\hline $73 \%$ & 2.2 & 44 & يراعي الترقيم الصحيح. \\
\hline $58 \%$ & 1.8 & 35 & يتجنب الاسهاب الممل والإيجاز المخل. \\
\hline $38 \%$ & 1.2 & 23 & يكتب في صورة مقالة علمية. \\
\hline $57 \%$ & 1.7 & 34 & يعقب على كل محور وعلى الفصل ككل. \\
\hline & & & الحادي عشر: منهج البحث \\
\hline & & & (المهار ات الفنية) \\
\hline $73 \%$ & 2.2 & 44 & بكتب المنهج المناسب للبحث. \\
\hline $67 \%$ & 2.0 & 40 & يحدد المجتمع والعينة المناسبتين. \\
\hline $63 \%$ & 1.9 & 38 & يتجنب الخلط بين العينة ومجموعة البحث. \\
\hline $58 \%$ & 1.8 & 35 & ملايمة العينة للمجتمع. \\
\hline $60 \%$ & 1.8 & 36 & يحدد أساليب إحصائيةٌ مناسبةة. \\
\hline $67 \%$ & 2.0 & 40 & يبين التصميم التجريبي. (إن وجد) \\
\hline $72 \%$ & 2.2 & 43 & يناسب التصميم التجريبي لطبيعة البحث ومتغير اته (إن وجد). \\
\hline $65 \%$ & 2.0 & 39 & يحدد أدوات بحث ملائمة. \\
\hline $72 \%$ & 2.2 & 43 & يوضح إجر اءات بناء الأدوات وضبطها. \\
\hline $45 \%$ & 1.4 & 27 & يربط الإجراءات بأسئلة البحث. \\
\hline & & & (المهارات اللغوية) \\
\hline $60 \%$ & 1.8 & 36 & ير اعي الدقة اللغوية في الكتابة. \\
\hline $75 \%$ & 2.3 & 45 & يستخدم صيغة المضارع في عرض الإجر اعات \\
\hline $67 \%$ & 2.0 & 40 & ير اعي الوضوح في عرض المنهج و الإجر اءات. \\
\hline $67 \%$ & 2.0 & 40 & يتبع نظام الفقرات في الكتابة. \\
\hline $65 \%$ & 2.0 & 39 & يوظف علامات الترقيم بصورة دقيقة. \\
\hline & & & الثاني عشر: التوثيق و المر اجع \\
\hline & & & (المهار ات الفنية) \\
\hline $72 \%$ & 2.2 & 43 & يراعي الاتساق و النظامية في التوثيق. \\
\hline $73 \%$ & 2.2 & 44 & يضمن قَائمةُ المر اجع كل ما ورد في المتن من مراجع. \\
\hline $85 \%$ & 2.6 & 51 & ير اعي الترتيب الهجائي في قائمة المر اجع. \\
\hline $67 \%$ & 2.0 & 40 & ير اعي الالتز ام بما جاء في دليل الكلية في التوثيق. \\
\hline $72 \%$ & 2.2 & 43 & ير اعي الحداثة في المر اجع. \\
\hline $52 \%$ & 1.6 & 31 & يكتب القرآن الكريم بدون رقم في قائمة المصادر. \\
\hline & & & (المهارات اللغوية) \\
\hline $67 \%$ & 2.0 & 40 & يراعي الدقة اللغوية في الكتابة \\
\hline $82 \%$ & 2.5 & 49 & يحذف ال التعريف عند الترتيب الهجائي في قائمة المر اجع. \\
\hline $73 \%$ & 2.2 & 44 & ير اعي النظامية في كتابة المر اجع والأُماء. \\
\hline $65 \%$ & 2.0 & 39 & يوظف علامات الترقيم بصورة دقيقة. \\
\hline
\end{tabular}

\section{OY}




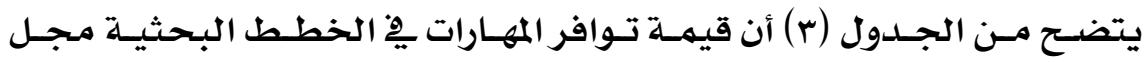

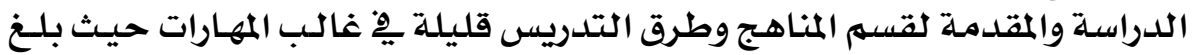

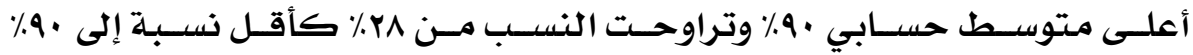

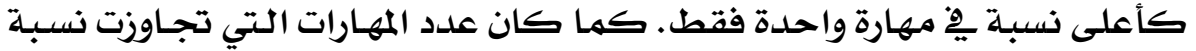

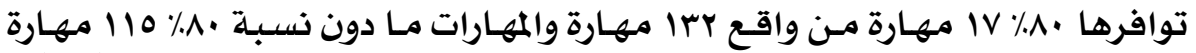

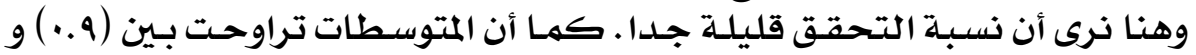

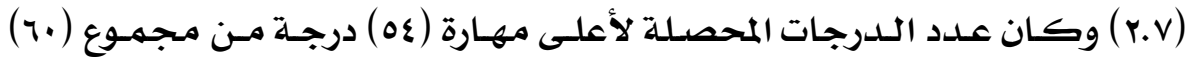

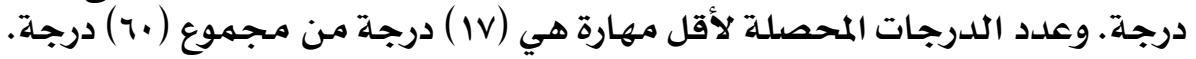

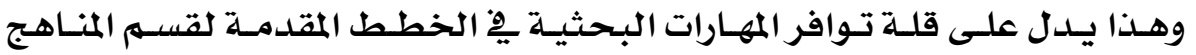
وطرق التدريس.

جلدول (ء) يوضح المتوسطات الحسابية والنسب المئوية لكل خطة بحثية

\begin{tabular}{|c|c|c|c|c|c|}
\hline النسبة & المتوسط & رقم الخطة & النسبة & المتوسط & رقم الخطة \\
\hline $67 \%$ & Y.. & 11 & $78 \%$ & Y.r & 1 \\
\hline $64 \%$ & 1.9 & Ir & $83 \%$ & Y.z & $r$ \\
\hline $73 \%$ & r. & 14 & $71 \%$ & Y. 1 & $r$ \\
\hline $67 \%$ & Y.. & $1 \leq$ & $78 \%$ & $r . r$ & $\varepsilon$ \\
\hline $68 \%$ & Y.. & 10 & $37 \%$ & 1.1 & 0 \\
\hline $65 \%$ & 1.9 & 17 & $70 \%$ & Y. & 7 \\
\hline $62 \%$ & 1.9 & IV & $57 \%$ & 1.7 & $\mathrm{~V}$ \\
\hline $65 \%$ & 1.9 & 11 & $64 \%$ & 1.9 & $\Lambda$ \\
\hline $66 \%$ & 1.9 & 19 & $65 \%$ & 1.9 & 9 \\
\hline $69 \%$ & Y.. & $r$. & $56 \%$ & 1.7 & 1. \\
\hline
\end{tabular}

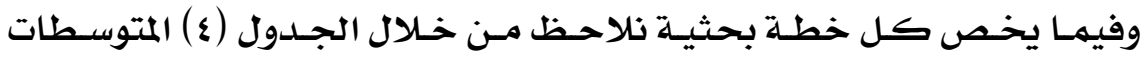

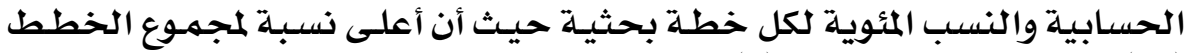

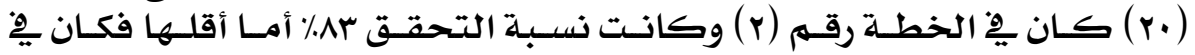

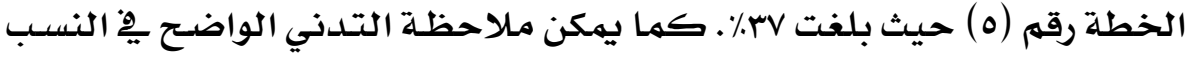

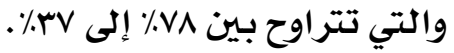

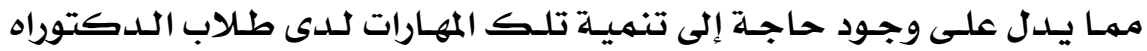

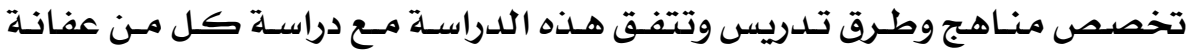

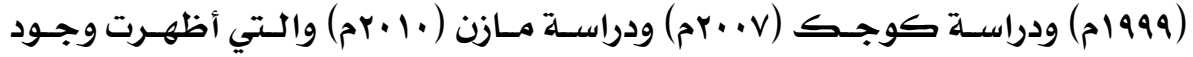

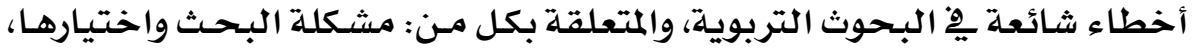

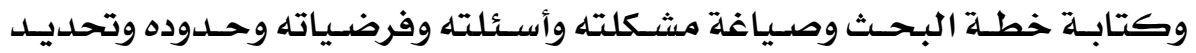

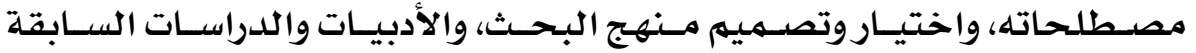

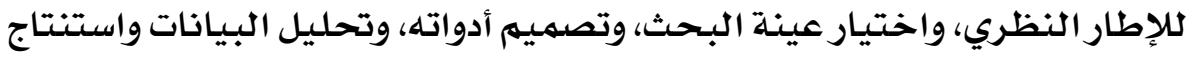
النتائج وعرض المراجي، واخئ.

\section{$\theta Y$}




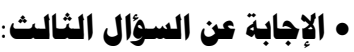

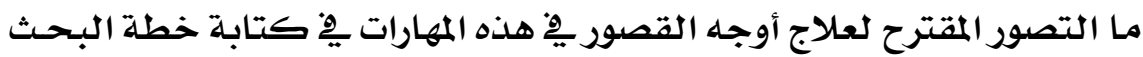

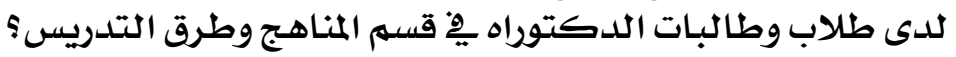

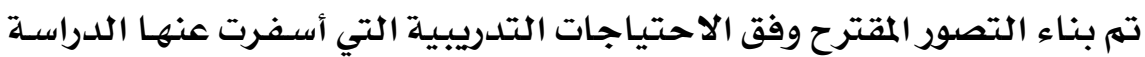

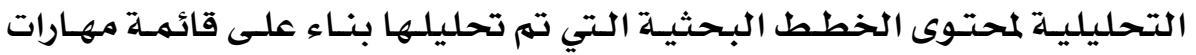

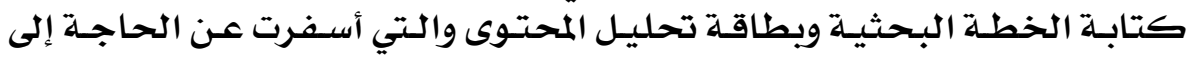
تنمية تلك المهارات لدى طلاب الدكتوراه تخديل تخصص مناهج وطرق تلدريس.

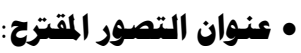
(تصور مقترح لتنمية مهارات كتابة الخطة البحثية لدى طلاب الدكتوراه تخصص مناهج وطرق تدريس). • الهدف العام هن التصور المترح:

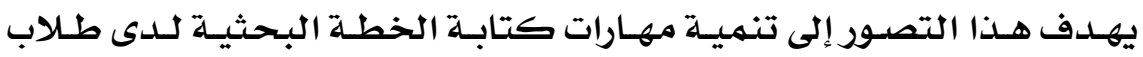
الدكتوراه تخصص مناهج وطرق تدريس يُّو ضوء احتياجاتهم التدريبية.

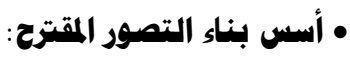

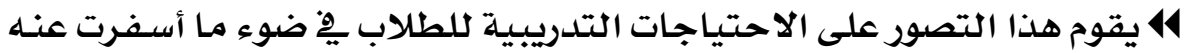

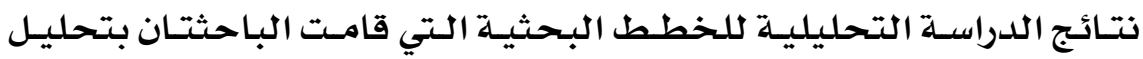

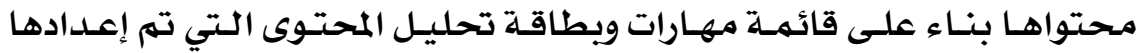

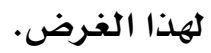

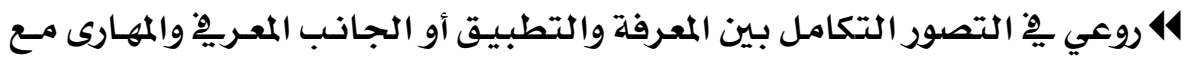

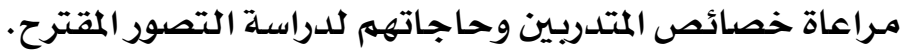

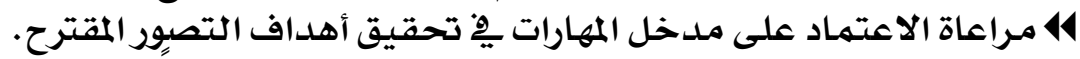

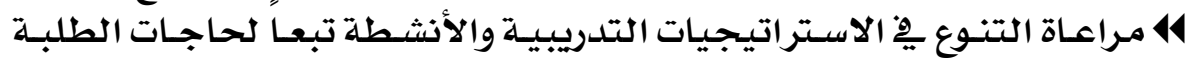
وطبيعة البر نامج وأهدافه.

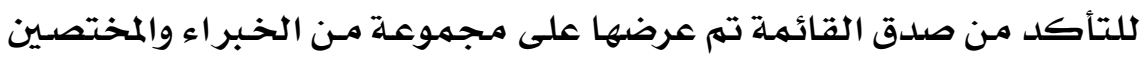

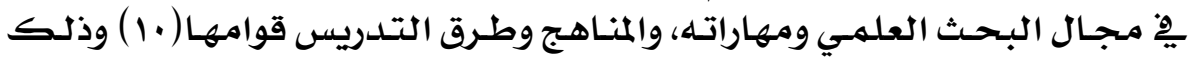

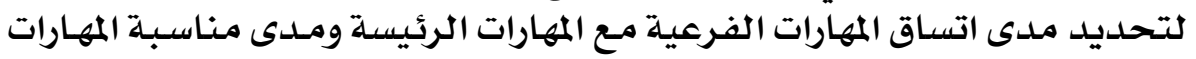

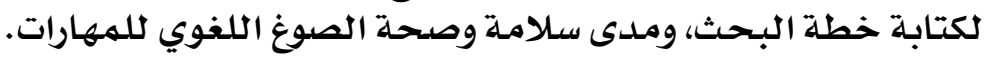

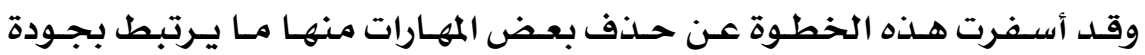

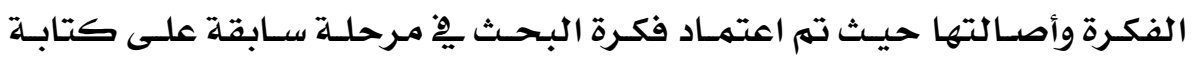

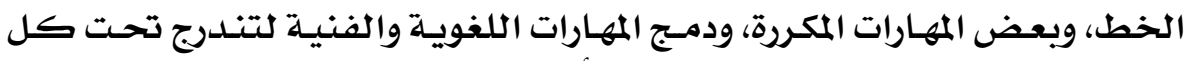
عنصر من عناصر الخطة البحثية وتم الأخذ بهذه الماته الملاحظات

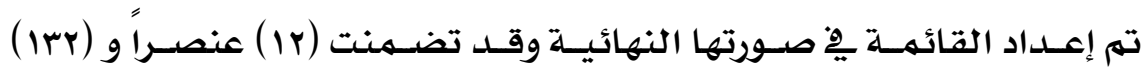
مهارة.

\section{\&}




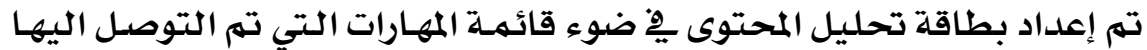

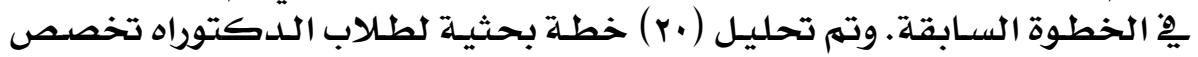

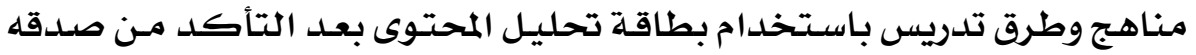

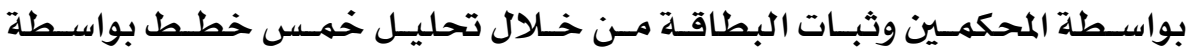

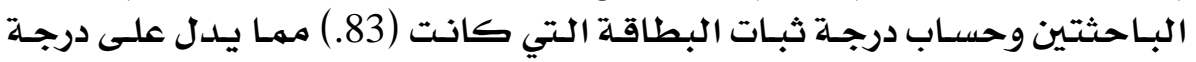

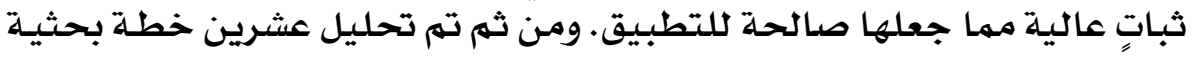

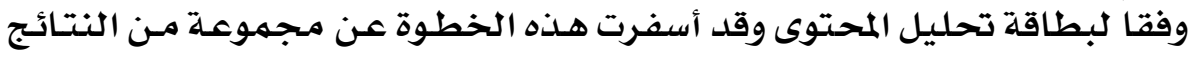

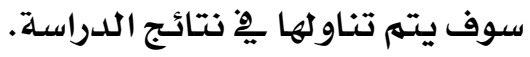

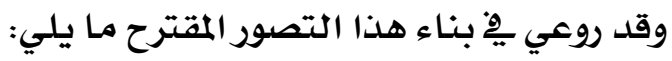

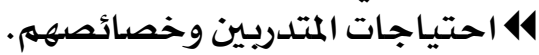

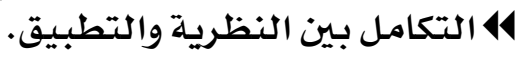

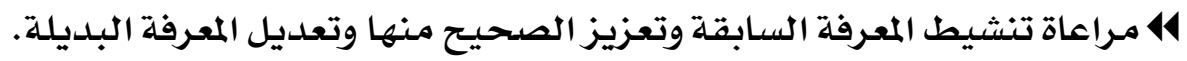
ه 414 • مصادر بناء التصور المقترح:

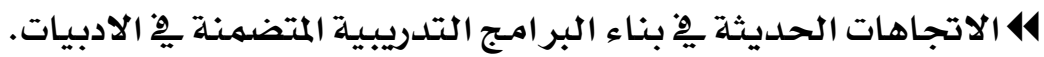

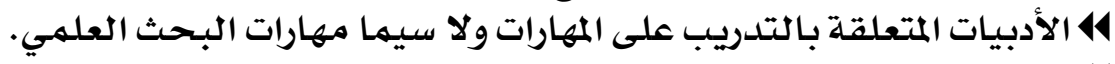

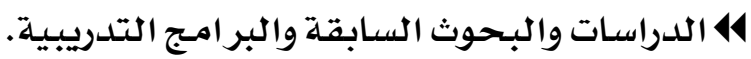

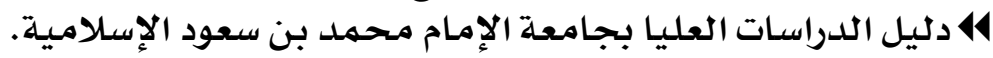

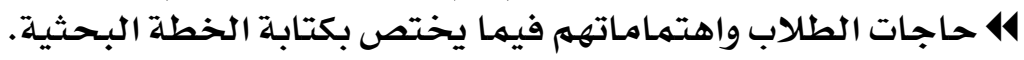

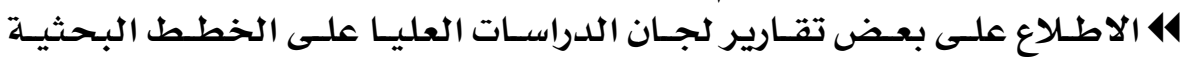
المقدمـة.

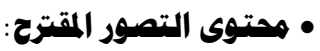

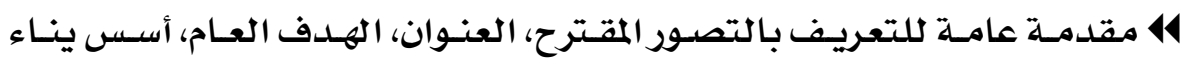

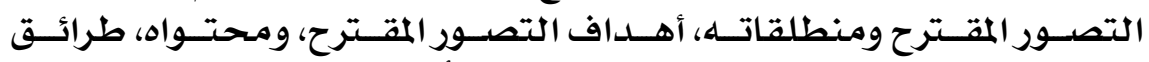

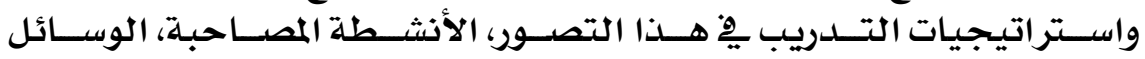

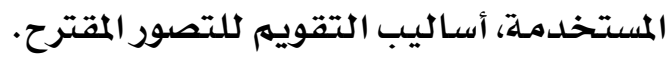

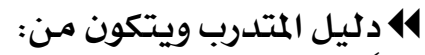

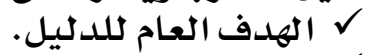
ل

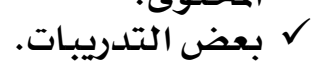

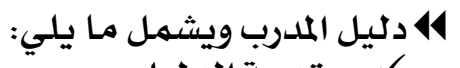
مقدمة الد الديل. ل ل المحتوى أهداف

\section{$\bullet \bullet$}




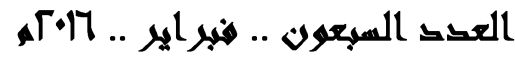

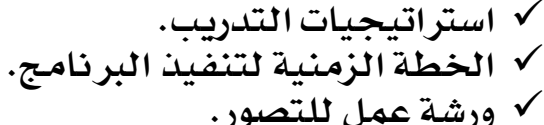

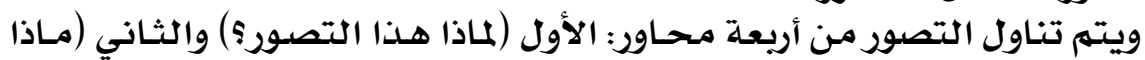

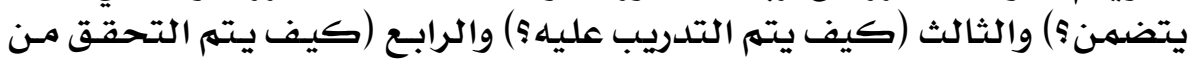
بلوغ أهدافه ؟) وفيما يلي عرض الهنا لهذا التصور • أولاً: لماذا هذا التصور: (أهدافه) وتم تحديد أهداف التصور لتشهل:

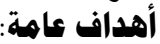

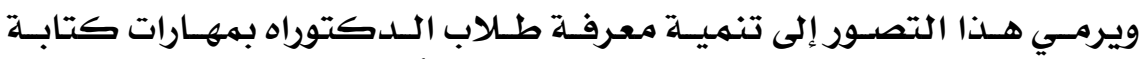
الخطة البحثية الفنية واللغوية، وتنمية مهاراتهم الأدائية لها. أهداف التصور الخاصة: - التهية

14 تنمية معرفة الطلاب (هدف الدراسة) بعناصر الخطة.

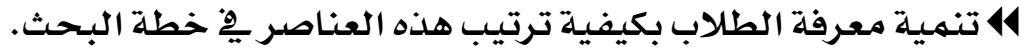

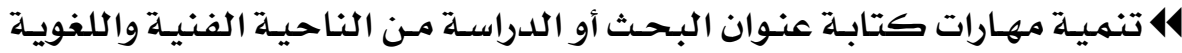

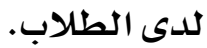

4ل تنمية مهارات كتابة مقدمة البحث أو الدراسة الفنية واللغوية.

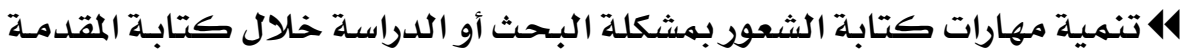
(الفنية واللغوية).

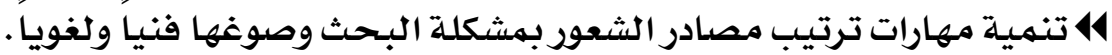

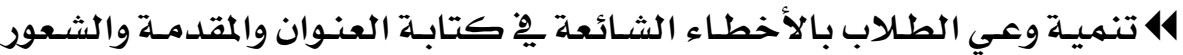
بالمشكلة.

ل1 تنمية مهارات كتابة تساؤلات البحث أو الدراسة الفنية واللغواتية.

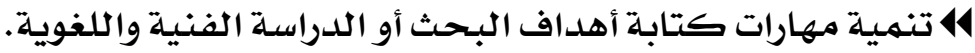

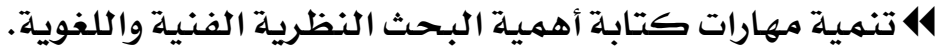

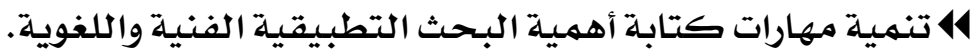

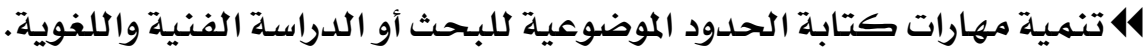

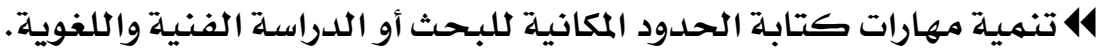

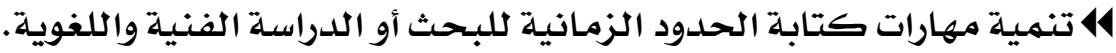

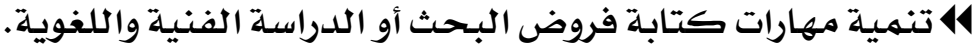

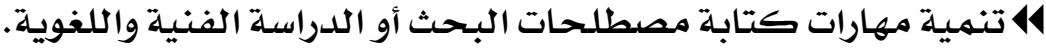

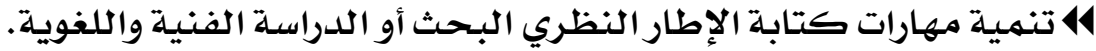

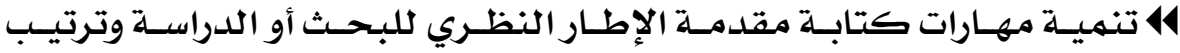
محاوره.

14 تنمية مهارات عرض الإطار النظري وكيفية التناول فنياً ولغوياً. 14 تنمية مهارات كتابة التعقيب على الإطار النظري.

\section{7}




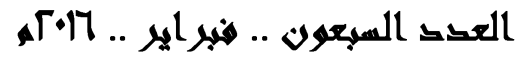

414 تنمية مهارات كتابة مقدمة الدراسات السابقة الفنية واللغوية.

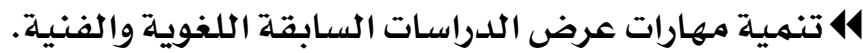

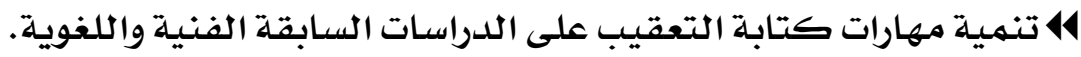

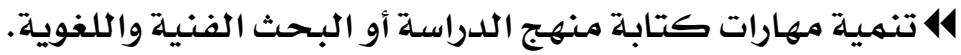
414 تنمية مهارات كتابة الإجراءات البهات البحثية الفنية والئة واللغوية.

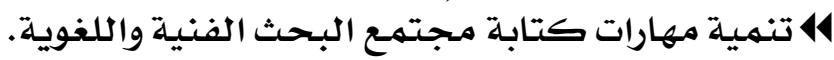

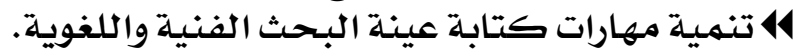

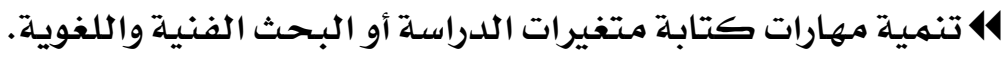

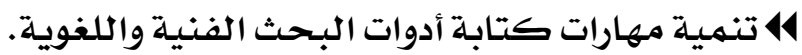

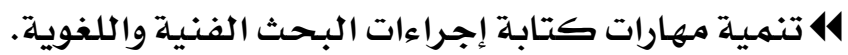

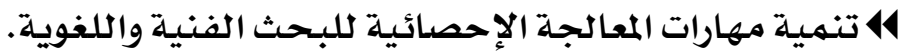

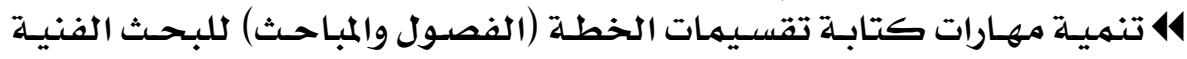

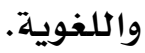

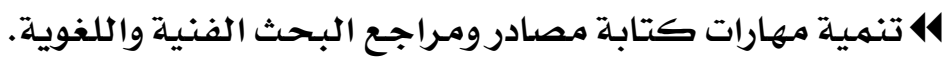

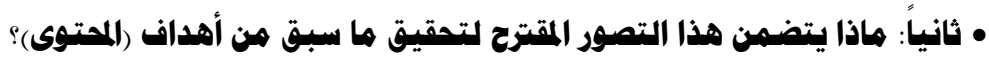

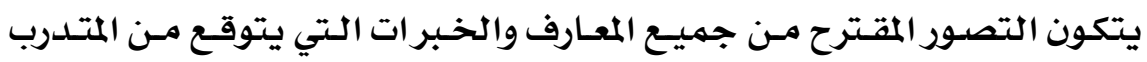

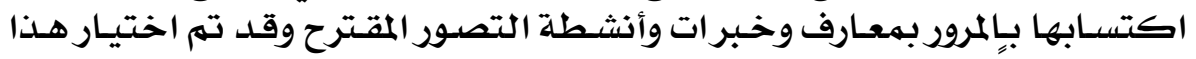

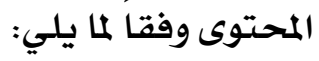

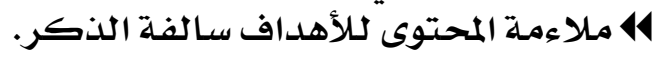

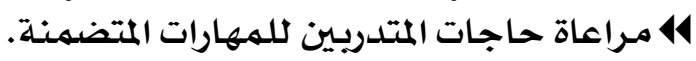

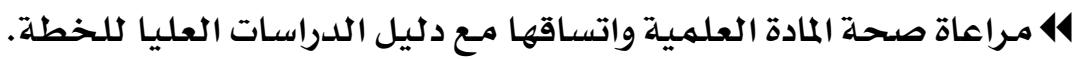

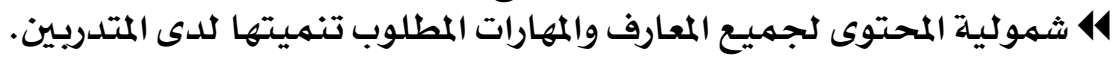

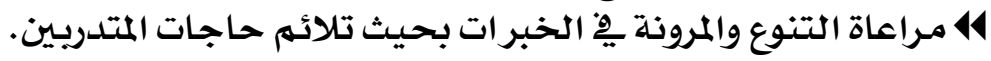

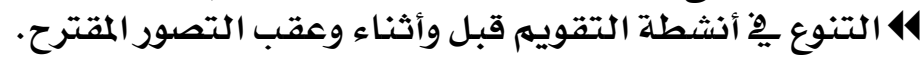

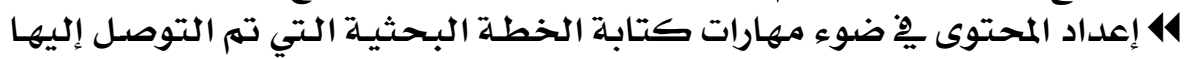

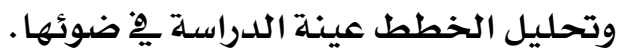

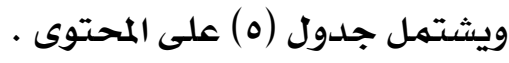

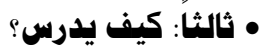

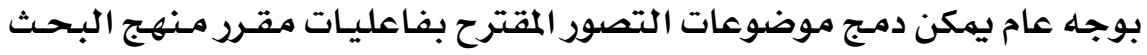

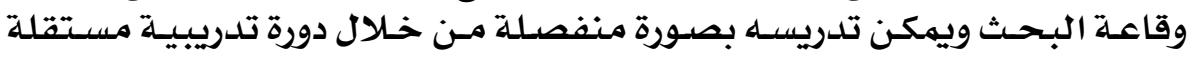

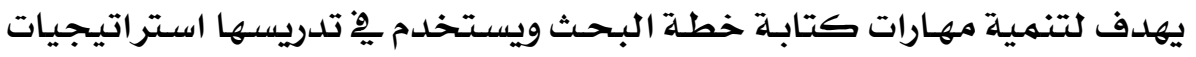

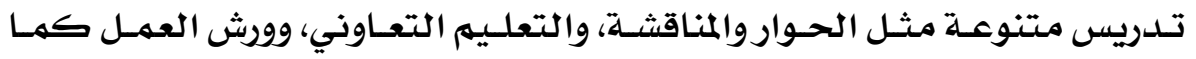

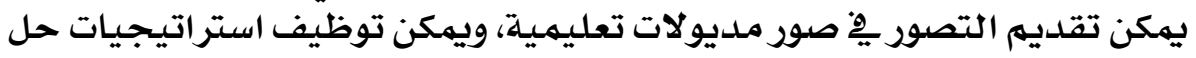
المشكلات والقدح الذهني وطريقة المشروعات الفردية والتعاونية.

\section{०}




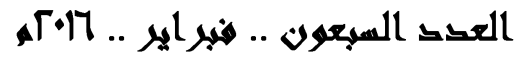

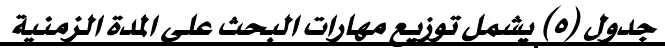

\begin{tabular}{|c|c|c|c|}
\hline المقان الزمن & الموضوعات الفرعية & الموضوع الرئيس & اللقاء \\
\hline ساعة - ل مسة & 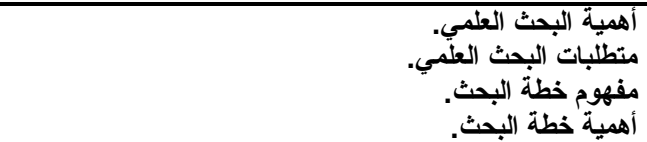 & لقاء تمهيدي & الأول \\
\hline ساعة & 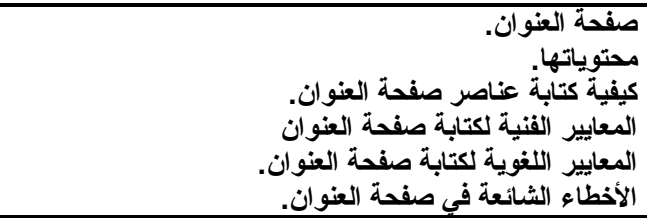 & عناصر خطة البحث & الثاني \\
\hline ساعة & 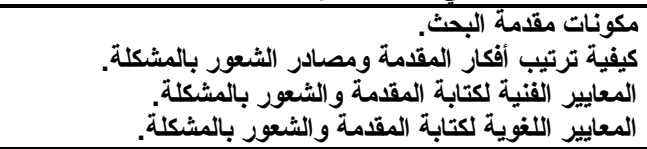 & 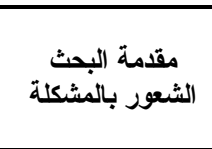 & الثالث \\
\hline ساعة & 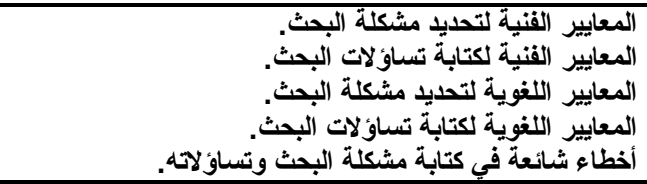 & تساولاتلات مشكلة & الرابع \\
\hline ساعة - ل مسة & 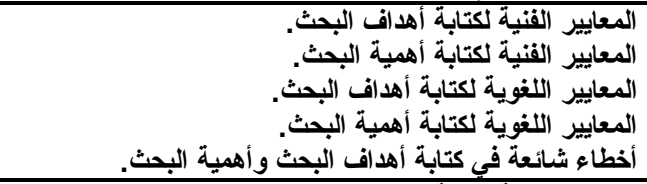 & أههية البحث & الخامس \\
\hline ساعة & 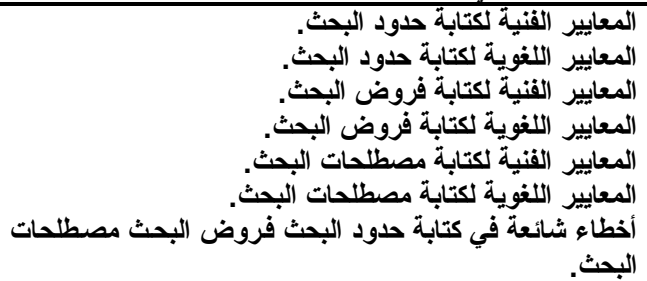 & فرطات البحثث & السادس \\
\hline ساعة & 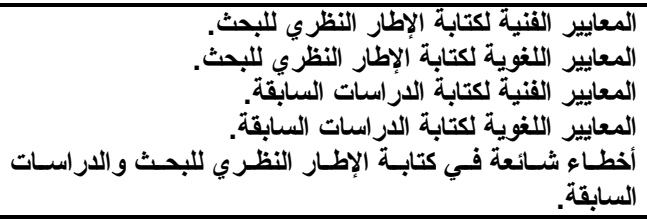 & الاراسات النظابقة & 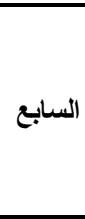 \\
\hline ساعة - ل مسة & 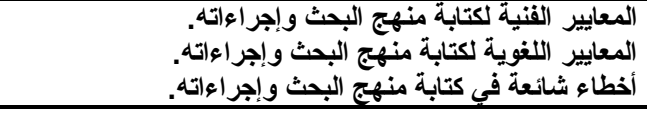 & إجراءهات البحثث & الثامن \\
\hline ساعة & أخطاييير اللغوئية لكتابة قائمة المتائمة المراجع. & قائمة المر اجع & التاسع \\
\hline ساعتان & 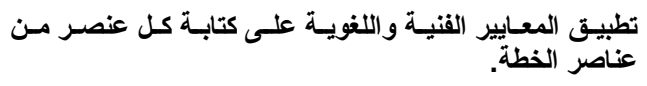 & تلريب تطبيقي & العاشر \\
\hline
\end{tabular}

\section{$\bullet \wedge$}




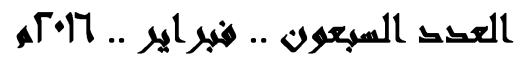

• رابعاً: كيف تتأكد من تقيق التصور القترح هن أهدافه:

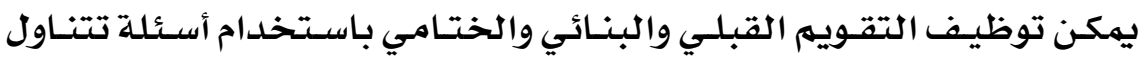

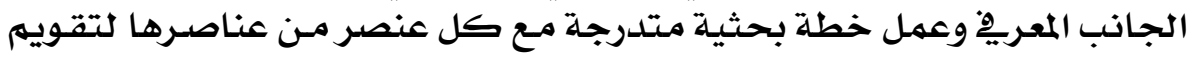

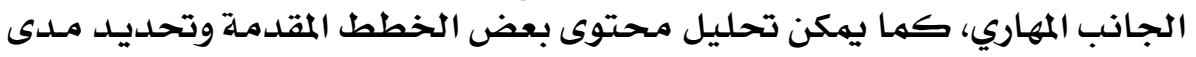

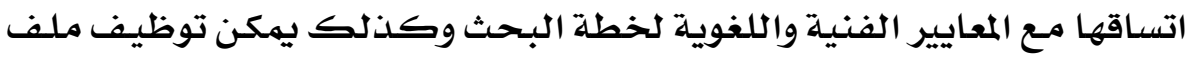
الإنجاز ِِّ تقويم فعاليات التصور المقترح ككل. وبهذا تكون تمت الإجابة على تساؤلات الدراسلة.

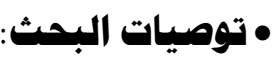

إِّوض ضوء نتائج هذا البحث يمكن تقديم التوصيات التالية:

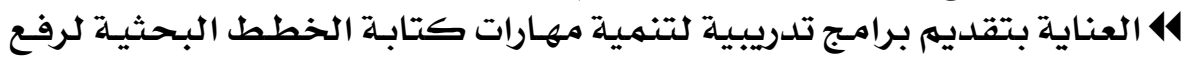

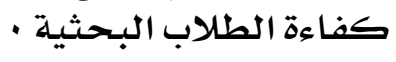

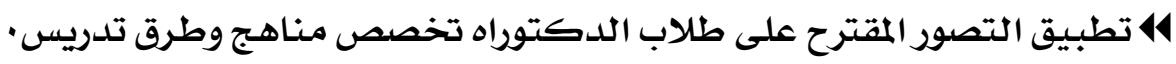

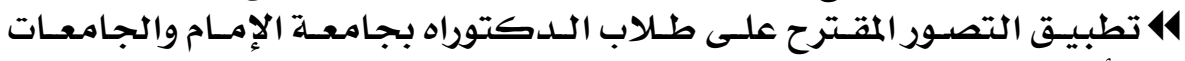

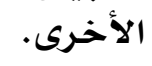

14 دمج التصور المقترح ِِّ مقرر مناهج البحث ِِّ مرحلة الدكتوراه.

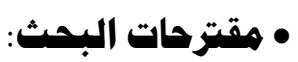

يقترح البحث الحالي إجراء الدراسات والبحوث التالية:

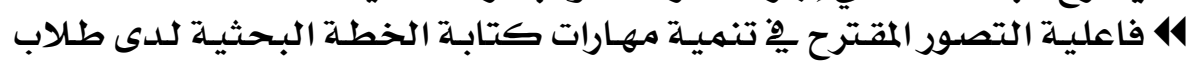
الدكتوراه تخصص مناهج وطرق تلفية تلدريس.

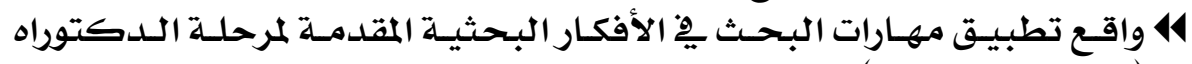

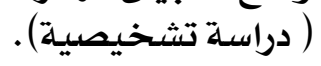

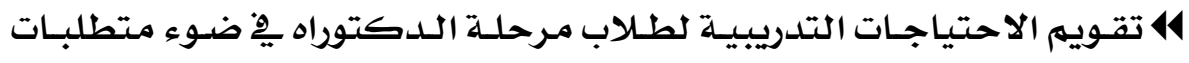
معايير الجودة. 14 برنامج مقترح لتنمية مهارات كتابة التقرير البحثي لدى طلاب الدراسات

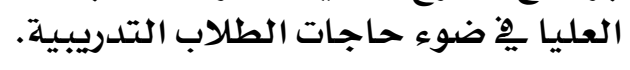

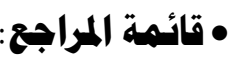

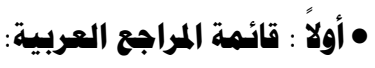

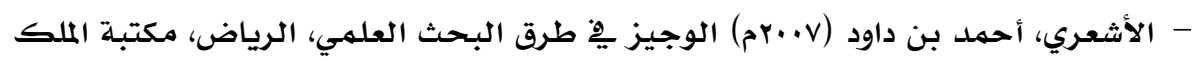

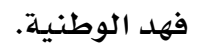

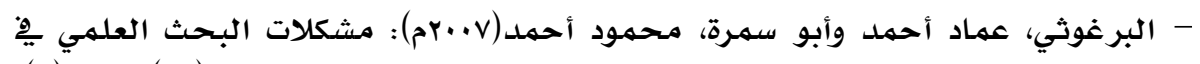

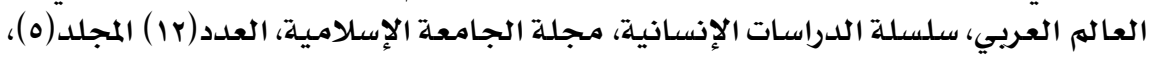

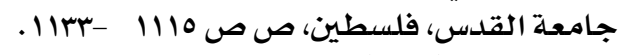

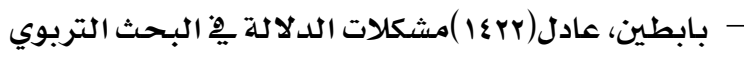

\section{9}

دراسات عربية في التربية وعلم النفس (ASEP) 


\section{العكى السبعول .. هنبراير ..}

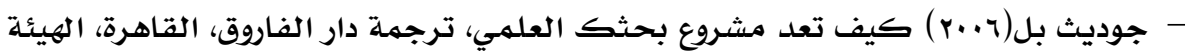
المصرية العامـة للكتاب. - جيرالد كمـب (19MVV) تصميهم البرامـاج التعليمية ترجمهة خيري كاظه، القاهرة، دار النهضة.

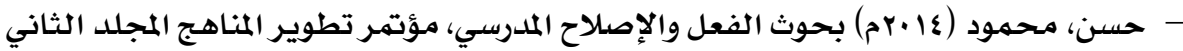

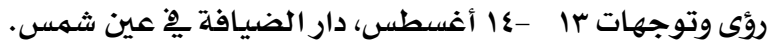

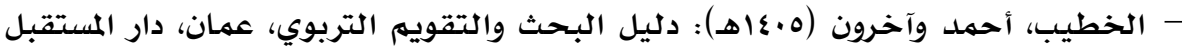
للنشر والتوزيع.

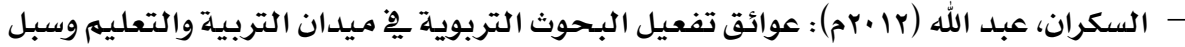

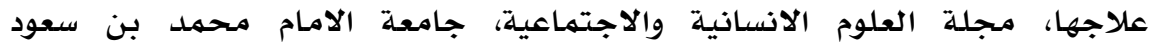

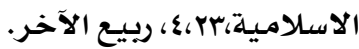

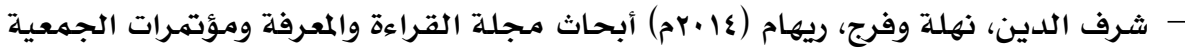

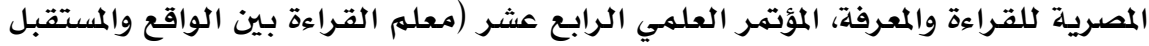
V I - I أغسطس، جامعلة عين شمس. -

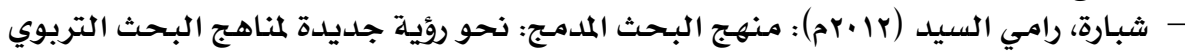

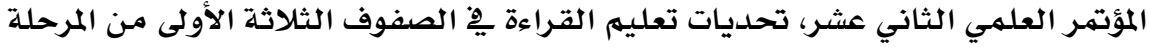

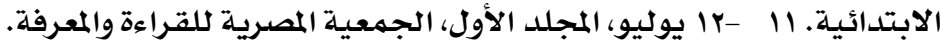

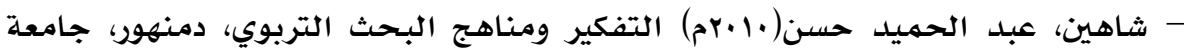
الاسكندرية. - صادق، آمال، أبو حطب، فؤاد(199؟م) علم النفس التربوي، طه، مصر، مكتبة الانجلو المصرية.

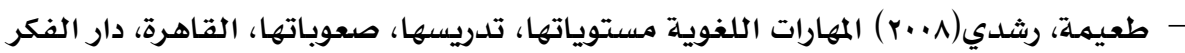
العربي. - العساف، صالح بن حمد. (اسجأهـ). المدخل إلى البحث يِّ العلوم السلوكية. الرياض: دار الزهراء. - العيسوي، جمال مصطفى(991ام) البحث العلمي يِ كليات المعلمـين بالمملكة العربية

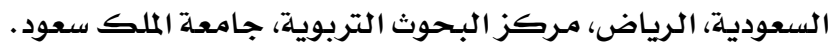

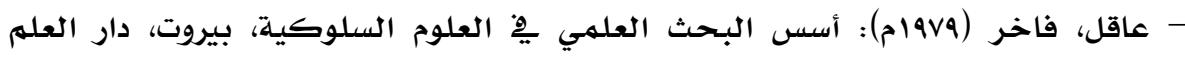
للملايين. عدس، عبد الرحمن، عبيدات، ذوقان، وكايد، عبد الحق(r...rم) البحث العلهي، مفهومـه،

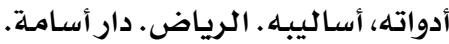

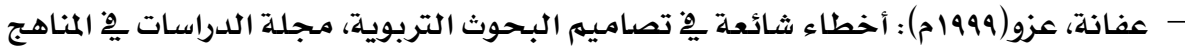

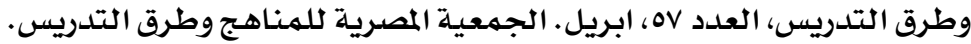

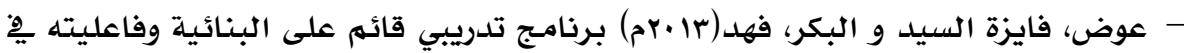

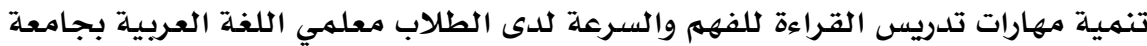

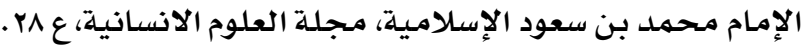

\section{7.}




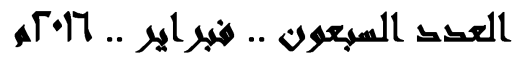

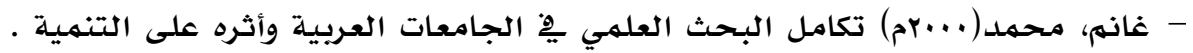

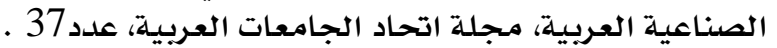

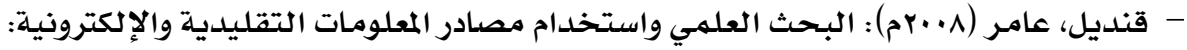

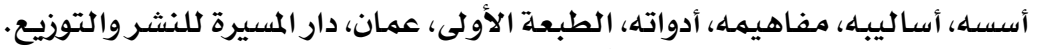

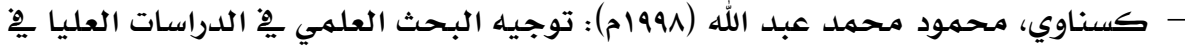

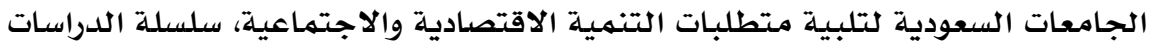

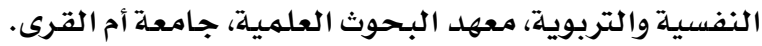

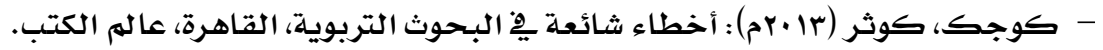

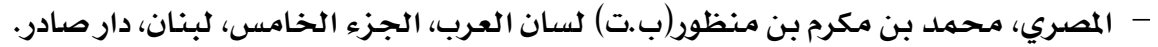

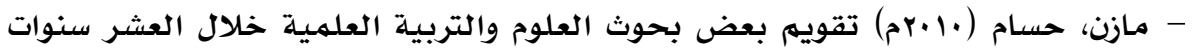

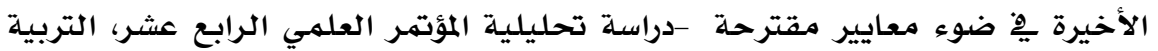

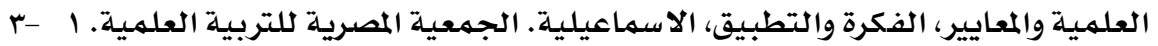

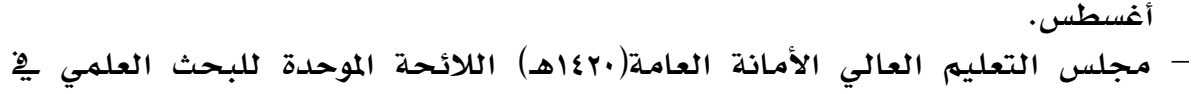

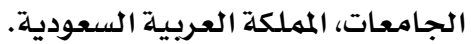

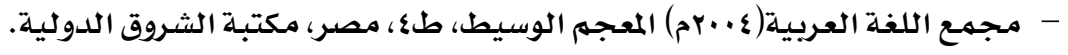

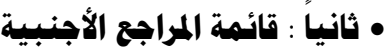

-Asplund T, Edwards H, O'Leary J, Ryan Y (1999) 'Tracking new directions in the evaluation of postgraduate supervision', Innovative Higher Education 24:2.

-Hou,Huei-Tsei Chang@ Kuo, En,Sung, Yao_Ting (2007): An Analysis of Peer Assessment Online Discussion within A Course that Uses Project-Based Learning, Interactive learning Environment, V.15 n.3,P.237-251.

-James, et al (2009)' An Instrument from self-appraisal of scientific research performance' International Journal of productivity and performance management V.58,N.7.

-John Milliken (2004) "Thematic on higher education postmodernism versus professionalism in higher education'. Higher education in Europe V.29,N.1.

-Oscar, R.(2009) "The Citation indexes and the quantification of knowledge' Journal of educational administration.

-Sakran, U(2006) Research methods for Business: A skill- Building Approach, Uthed ,N.Y, Johnsons Wiley. 
-Shi, Ling \& Reader, Ken(2004)"Tensions in Learning Content and Technology: The Experience of Education Students in a Research Project Technology, Pedagogy and Education", V.13,N.1. March .ERIC. EJ821954.

-Stracke, E., \& Kumar, V. (2010) "Feedback and self-regulated learning. Insights from supervisors' and $\mathrm{PhD}$ examiners' reports". Reflective Practice. 11(1). in print.

-Yin,R(2008) "Case Study Research: Design and Methods $\left(4^{\text {th }}-\right.$ Ed $)$ Thousand Oaks, CA;Sage. 